\title{
Cianobactérias como indicadoras de poluição nos mananciais abastecedores do Sistema Cantareira
}

\author{
Paulo Batista do Nascimento
}

Dissertação apresentado ao Programa de PósGraduação em Saúde Pública da Faculdade de Saúde Pública da Universidade de São Paulo para obtenção do título de Mestre em Saúde Pública.

Área de Concentração: Saúde Ambiental

Orientador: Prof. Dr. José Luiz Negrão Mucci

São Paulo

2010 
É expressamente proibida a comercialização deste documento tanto na sua forma impressa como eletrônica. Sua reprodução total ou parcial é permitida exclusivamente para fins acadêmicos e científicos, desde que na reprodução figure a identificação do autor, título, instituição e ano da dissertação.

Assinatura:

Data: 
Dedicatória

A minha querida mãe (Joana) pelo bom
exemplo de pessoa humana, sábia e
temente a Deus, pelos bons conselhos
e atitudes diante das dificuldades da
vida, assim como toda a minha
familia, pai (Antônio Augusto) e
irmãos (Gessé, Dedé, Agostinho, Zé
Antônio, Aloísio, Edivaldo, Gervásio,
Fernando, Lúcia e Everaldo).




\section{Agradecimentos}

Agradeço a Deus por tudo que tem feito por mim, sem Deus eu não teria chegado até aqui, o Senhor é a minha força.

- Senfor, obrigado por eu ter nascido numa boa família, por ter sempre encontrado pessoas de alma gentil, de bom coração e de grandes qualidades como pessoa.

Agradeço ao meu orientador, Dr. José Luiz Negrão Mucci, que permitiu ao meu ingresso em mestrado, e pela sua excelente ajuda na elaboração da minha dissertação $e$ também por repassar muitos dos seus conhecimentos na área de saúde pública, pois foi muito enriquecedor na minha área de trabalho.

Á Faculdade de Saúde Pública da Universidade de São Paulo que me ofereceu uma excelente oportunidade de aprimorar meus conhecimentos acadêmicos, assim como na minha profissão de biólogo em que estou atuando no campo de saneamento básico.

Á Compantia de Saneamento Básico do Estado de São Paulo (SABESP) que por intermédio da minha gerente de divisão do Controle Sanitário $\mathcal{N}$ orte ( $\mathcal{M} \mathcal{N E C}$ ), Rita, e do meu encarregado, Cícero, juntamente com meus colegas e ex-colegas de serviço: Aderval, Alekssandra, Aroldo, Bruna, Darci, Denise, Eliana, Flausino, Flávia, Dona Graça, Letícia, Luana, Luiz, Manoel, Marcos Gianini, Marcos Rodrigues, Mauro, Rosângela, Serginho, Simone, Valdir, Vanderlei, Wilson.

À TOQ, setor de treinamento hidrofiológico da SABESP, ao qual dediquei o meu maior tempo de treinamento em hidrobiologia: Ana Lúcia Szajubok Beatriz, Eduardo, Celina, Cícero, Eli, Lígia, Vera, Vilma.

Ao Luiz Antônio, biólogo do Controle Sanitário da Sabesp (MLEC) que participou no princípio dos meus primeiros conhecimentos sobre hidrobiologia.

Á Dra. Célia Santana por ter repassado, sob sua orientação, seus conhecimentos no meu treinamento na identificação de cianobactérias e algas em geral no Instituto de Botânica de São Paulo.

Ao Dr. Aristides e à Dra. Marcina por terem contribuído de forma analítica com seus conhecimentos para o enriquecimento do meu trabalho. 


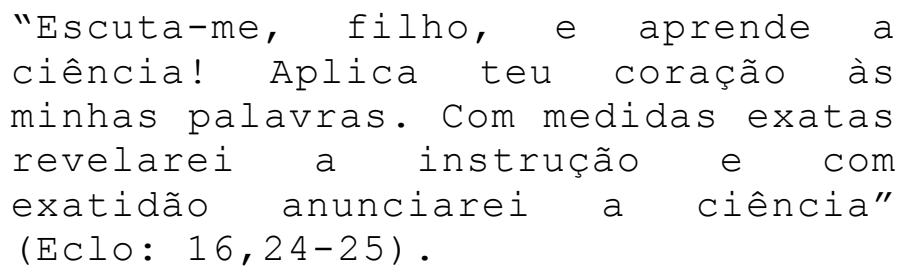

"Foi o Senhor quem deu a ciência aos seres humanos, para que pudessem glorificá-lo por suas maravilhas" (Eclo: 38,6$)$.

- Deus não é contra a ciência, pois a própria ciência emana do Criador, Deus é contra a quem faz mal uso dela.

"Fazei tudo o que Ele vos disser" ( Jo: 2,5$)$. 


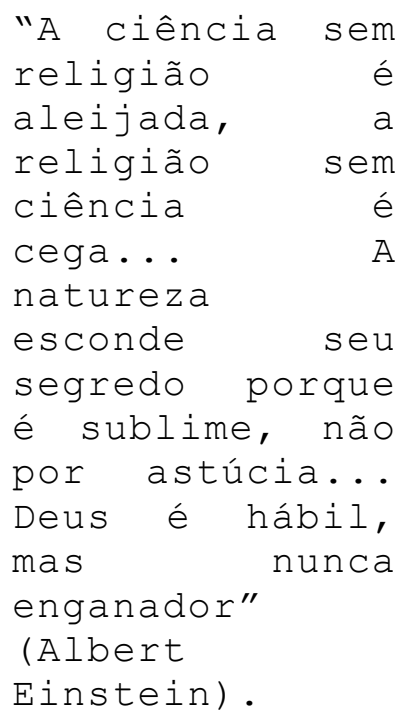




\section{RESUMO}

Introdução: Os problemas ambientais estão ocorrendo cada vez com mais freqüência, e um destes problemas está relacionado com a água, pois águas de boa qualidade na natureza estão ficando mais escassas. objetivo: O objetivo do presente estudo é avaliar as condições ambientais em que se encontram as águas captadas por 4 estações de tratamento de água, sendo cada uma delas localizadas em 4 cidades, as quais são: Bragança Paulista, Piracaia, Nazaré Paulista e Mairiporã; e cujas águas são pertencentes aos mananciais que fazem parte do Sistema Cantareira. Metodologia: A metodologia está baseada a partir de dados secundários obtidos de relatórios e análises realizadas pela SABESP (Companhia de Saneamento Básico do Estado de São Paulo), no período de 2002 a 2008. Uma das formas de avaliação dos efeitos da poluição causados por mudanças ambientais ou atividades antrópicas, sobre a vida aquática dos mananciais, pode ser com o uso de bioindicadores. Variáveis bióticas e abióticas são as ferramentas deste estudo que estão inter-relacionadas, dependendo da influência que uma causa sobre a outra. Como variável biótica que indica poluição, destaca-se as cianobactérias, por serem estas resistentes aos poluentes. Este trabalho busca informações de variáveis abióticas em decorrência da própria mudança ambiental, para melhor avaliação sobre as variáveis bióticas fornecidas por microrganismos planctônicos como o crescimento de cianobactérias em águas continentais, por exemplo, aumento de poluentes como - excesso de nitrogênio e fósforo total do corpo d'água, alterações de natureza climática como a variação de temperatura da água, e a concentração de oxigênio dissolvido da água. Para efeito de comparação com as cianobactérias, foram utilizadas as algas verdes, desta forma procurou-se avaliar num determinado período de tempo as condições ambientais das águas captadas pelas estações de tratamento situadas ao longo do Sistema Cantareira, mostrando que o crescimento da densidade de cianobactérias aponta para um aumento gradual de poluição. Resultados: Os resultados indicam que no período do estudo, houve um aumento no número de cianobactérias em todos os reservatórios considerados: Bragança Paulista (75\%), Piracaia (105\%), Nazaré Paulista (22\%) e Mairiporã (179\%). 


\section{ABSTRACT}

Introduction: The environmental problems are happening every time with more frequency, and one of these problems is related with the water, because waters of good quality in the nature are being scarcer. objective: The objective of the present study is to evaluate the environmental conditions in that meet the waters captured by 4 water treatment plants, being located each one of them in 4 cities, which are: Bragança Paulista, Piracaia, Nazaré Paulista and Mairiporã; and whose waters are belonging to the sources that are part of the Cantareira system. Method: The methodology is based starting from obtained secondary data of reports and analyses accomplished by SABESP (Company of Basic Sanitation of the state of São Paulo), in the period from 2002 to 2008. One in the ways of evaluation of the effects of the pollution caused by environmental changes or anthropogenic activities, about the aquatic life of the watershed, it can be with the bioindicators use. Variable biotics and abiotics are the tools of this study that are interrelated, depending on the influence that a cause on the other. As variable biotic that indicates pollution, stands out the cianobactérias, for they be these resistant ones to the pollutants. This work search for information of abiotic variables due to the own environmental change, for better evaluation on the biotic variables supplied by planktonic microorganisms as the cyanobacteria growth in continental waters, for example, increase of pollutants as the excess of nitrogen and total phosphorus of the body of water, alterations of climatic nature as the variation of temperature of the water, and the concentration of dissolved oxygen of the water. For comparison effect with the cyanobacterias, the green algae were used, this way it tried to evaluate in a certain period of time the environmental conditions of the waters captured by the treatment plants located along the Cantareira system, showing that the growth of the cyanobacteria density indicate for a gradual increase of pollution. Results: The results indicate that in the period of the study, there was an increase in the cyanobacteria number in all the considered reservoirs: Bragança Paulista (75\%), Piracaia (105\%), Nazaré Paulista (22\%) and Mairiporã (179\%). 


\section{ÍNDICE}

1 INTRODUÇÃO 13

$\begin{array}{ll}1.1 \text { CIANOBACTÉRIAS } & 16\end{array}$

1.2 CIANOBACTÉRIAS COMO INDICADORES DE POLUIÇÃO 20

1.3 TOXINAS DE CIANOBACTÉRIAS E SAÚDE PÚBLICA 26

2 JUSTIFICATIVA 32

3 OBJETIVO 33

4 MATERIAIS E MÉTODOS 34

4.1 ÁREA DE ESTUDO 34

4.2 OBTENÇÃO DAS AMOSTRAS E LEVANTAMENTO DE DADOS 40

4.3 PARÂMETROS FíSICOS DA ÁGUA 41

4.3.1 Cor 41

4.3.2 Turbidez 41

4.3.3 Temperatura $\quad 42$

4.4 PARÂMETROS QUÍMICOS DA ÁGUA 42

4.4.1 Oxigênio Dissolvido $\quad 42$

4.4.2 Nitrogênio 43

4.4.3 Fósforo 43

4.4.4 Potencial Hidrogeniônico 43

4.5 PARÂMETRO BIOLÓGICO 44

5 VARIÁVEIS 46

5.1 VARIÁVEIS BIOLÓGICAS 46

5.1.1 Cianobactérias 46

5.1.2 Algas Verdes 46

5.2 VARIÁVEIS AMBIENTAIS $\quad 47$

5.2.1 Temperatura 47

5.2.2 Fósforo Total 47

5.2.3 Nitrogênio 48

5.2.4 Oxigênio Dissolvido 49

5.2.5 Cor, Turbidez e pH 50

5.3 ÍNDICE DE ESTADO TRÓFICO (IET) 51 
6 RESULTADOS 56

6.1 VARIÁVEIS BIOLÓGICAS

6.1.1 Cianobactérias e Algas Verdes 56

6.1.2 Níveis de Densidades de Cianobactérias das Estações de Tratamento de Água entre 2002 e $2008 \quad 60$

6.1.3 Cianobactérias X Algas Verdes 63

6.2 VARIÁVEIS AMBIENTAIS 66

6.2.1 Temperatura 66

6.2.2 Concentração de Fósforo Total e Categorias de Estado Trófico das Águas de Captação das 4 Estações em Estudo 71

6.2.3 Nitrogênio na Forma de Nitrato 74

6.2.4 Nitrogênio na Forma de Nitrogênio Amoniacal 75

6.2.5 Oxigênio Dissolvido 79

6.2.6 Cor, pH e Turbidez 80

6.2.7 Destaque para Cor e Oxigênio Dissolvido na Água Bruta da ETA de Bragança Paulista 81

7 DISCUSSÃO 82

7.1 VARIÁVEIS BIOLÓGICAS

7.1.1 Cianobactérias 83

7.1.2 Algas Verdes 88

7.1.3 Cianobactérias X Algas Verdes 88

7.2 VARIÁVEIS AMBIENTAIS 90

7.2.1 Temperatura 90

7.2.2 Fósforo Total 91

7.2.3 Nitrogênio 95

7.2.3.1 Nitrato 97

7.2.3.2 Nitrogênio Amoniacal 99

7.2 .4 Oxigênio Dissolvido 100

7.2.5 Cor, Turbidez e pH 102

7.3 RELAÇÕES ENTRE AS VARIÁVEIS BIÓTICAS E ABIÓTICAS 106

8 CONSIDERAÇÕES FINAIS

9 REFERÊNCIAS BIBLIOGRÁFICAS BÁSICAS 113 


\section{Lista de Figuras}

Figura 1 - Mapa da área de estudo. 35

Figura 2 - Esquema do Sistema Cantareira com suas represas e ETAs. 37

Figura 3 - Perfil esquemático ilustrativo do Sistema 38

Figura 4 - Cianobactérias na água de captação da ETA de Bragança Paulista. 56

Figura 5 - Algas Verdes na água de captação da ETA de Bragança Paulista. 56

Figura 6 - Cianobactérias na água de captação da ETA de Piracaia.

Figura 7 - Algas Verdes na água de captação da ETA de Piracaia.

Figura 8 - Cianobactérias na água de captação da ETA de Nazaré Paulista.

Figura 9 - Algas Verdes na água de captação da ETA de Nazaré Paulista.

Figura 10 - Cianobactérias na água de captação da ETA de Mairiporã.

Figura 11 - Algas Verdes na água de captação da ETA de Mairiporã.

Figura 12 - Demonstração gráfica do desenvolvimento de cianobactérias nas águas de captação das 4 estações de tratamento de água.

Figura 13 Fotos de cianobactérias.

Figura 14 Fotos de algas verdes.

Figura 15 - Comparação entre cianobactérias e algas verdes nas águas de captação em cada estação no período entre os anos de 2002 a 2008 (média).

Figura 16 - Taxa ( $\left.\frac{\circ}{0}\right)$ de crescimento de cianobactérias e decaimento de algas verdes no período entre os anos de 2002 a 2008 nas quatro ETAs. 
Figura 17 - Variação da Temperatura na água de captação da ETA de Bragança Paulista.

Figura 18 - Variação da Temperatura na água de captação da ETA de Piracaia.

Figura 19 - Variação da Temperatura na água de captação da ETA de Nazaré Paulista.

Figura 20 - Variação da Temperatura na água de captação da ETA de Mairiporã.

Figura 21 - Variação da concentração de Fósforo total nas águas de captação das ETAs de Bragança Paulista (33B1) e Piracaia (42B1).

Figura 22 - Variação da concentração de Fósforo total nas águas de captação das ETAs de Nazaré Paulista (41B1) e Mairiporã (19B1).

Figura 23 - Variação da concentração de Nitrato na água de captação das ETAs de Bragança Paulista (33B1), Piracaia (42B1), Nazaré Paulista (41B1) e Mairiporã(19B1) .

Figura 24 - Variação da concentração de Nitrogênio Amoniacal na água de captação da ETA de Bragança Paulista.

Figura 25 - Variação da concentração de Nitrogênio Amoniacal na água de captação da ETA de Piracaia.

Figura 26 - Variação da concentração de Nitrogênio Amoniacal na água de captação da ETA de Nazaré Paulista.

Figura 27 - Variação da concentração de Nitrogênio Amoniacal na água de captação da ETA de Mairiporã .

Figura 28 - Variação da concentração de Oxigênio Dissolvido na água de captação das ETAs de Bragança Paulista (33B1), Piracaia (42B1), Nazaré Paulista (41B1) e Mairiporã (19B1). 


\section{Lista de Tabelas}

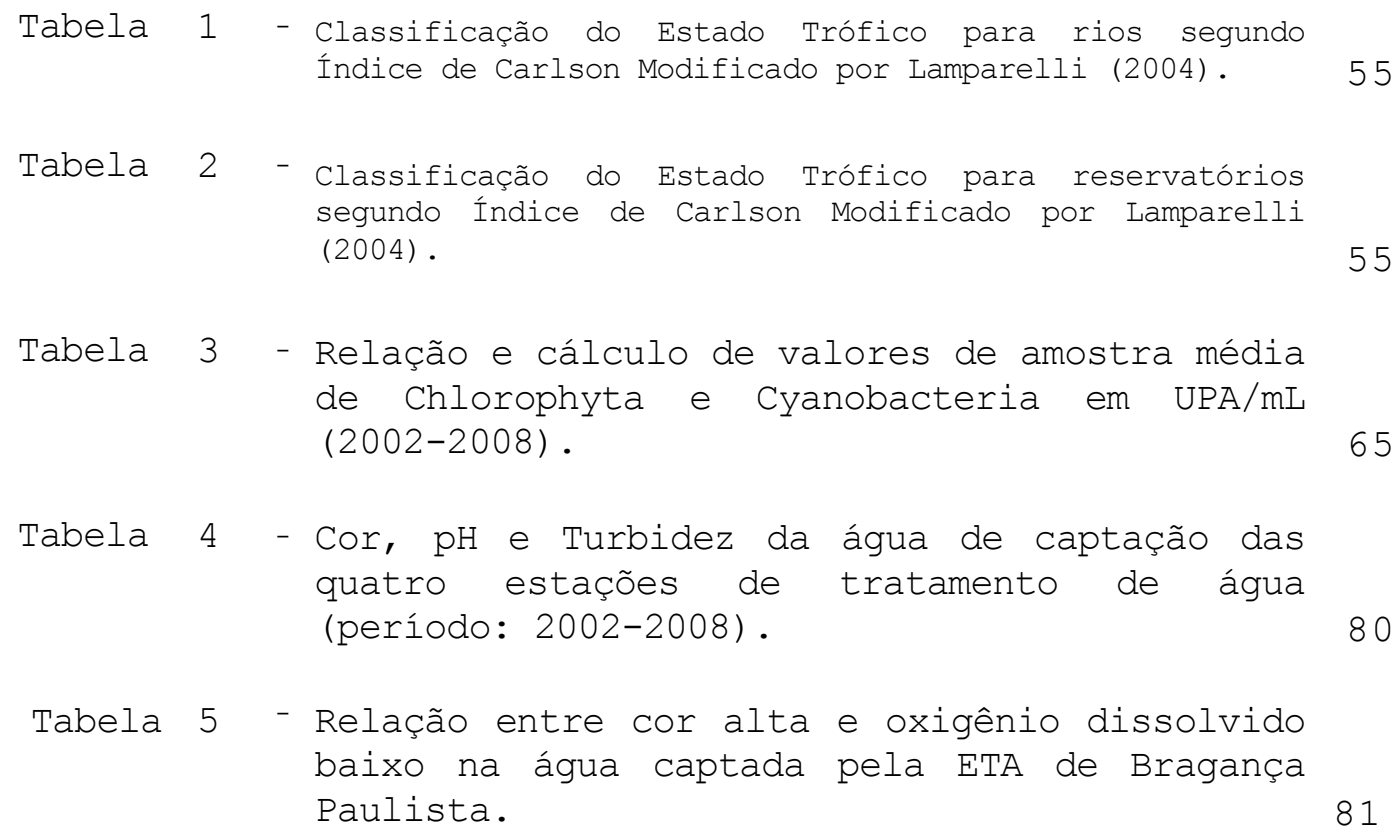

Tabela 3 - Relação e cálculo de valores de amostra média de Chlorophyta e Cyanobacteria em UPA/mL (2002-2008).

Tabela 4 - Cor, pH e Turbidez da água de captação das quatro estações de tratamento de água (período: 2002-2008). 80

Tabela 5 - Relação entre cor alta e oxigênio dissolvido baixo na água captada pela ETA de Bragança Paulista.

\section{Lista de Quadros}

Quadro 1 - Situação dos mananciais do Sistema Cantareira e Guarapiranga-Billings.

Quadro 2 - Meses que apresentaram as mais altas e as mais baixas temperaturas entre o período de 2002 e 2008 nas seguintes ETAs: Bragança Paulista (33B1), Piracaia (42B1), Nazaré Paulista (41B1) e Mairiporã (33B1) . 


\section{INTRODUÇÃO}

Atualmente, a qualidade das águas em muitas
regiões do mundo revela o descaso com que foram
tratadas, as descargas industriais, urbanas e da
agricultura, nas atividades humanas, assim como a má
utilização e o planejamento inadequado do recurso.

Uma grande parte deste recurso está armazenada em reservatórios artificiais e ocupam cerca de 7.500 $\mathrm{Km}^{2}$ de águas represadas em todo o planeta. O gerenciamento desses ecossistemas artificiais, da qualidade de sua água e das bacias hidrográficas na qual se inserem esses reservatórios é de fundamental importância para o desenvolvimento sustentável (Straskraba e Tundisi, 2000), citados por GEMELGo, 2008 .

No caso dos corpos de águas superficiais que servem como mananciais para abastecimento humano, o problema é maior ainda, uma vez que podem trazer problemas de saúde pública em razão da utilização inadequada desses ambientes pelo homem. A contaminação das águas é um destes grandes problemas devido à ocupação humana inadequada próxima destes reservatórios.

O risco de agravos à saúde se deve ao fato de que o excesso de matéria orgânica e inorgânica na água, proveniente de descargas de esgoto doméstico ou 
industrial ou ainda de fertilizantes em áreas agrícolas, provoca o aumento no teor de nutrientes (eutrofização) e, uma vez havendo luz suficiente, ocorre um aumento na taxa de fotosíntese pelo fitoplâncton.

Assim, em ambientes aquáticos ricos em
nutrientes, podem ocorrer florações de macrófitas
aquáticas e também de algas, principalmente
cianobactérias tóxicas.

A degradação da qualidade da água dos mananciais ocorre devido ao processo de eutrofização, que segundo BRANCO (1986, p.352), é "a transformação de um meio oligotrófico (pobre em nutrientes) em eutrófico (rico em nutrientes)", e ainda destaca que "várias experiências têm demonstrado que, se por um lado, a elevação do teor de nitrogênio e de fósforo dos cursos d'água quase sempre leva a um correspondente aumento da proliferação de microrganismos autótrofos. O mesmo, no entanto, não se dá com relação ao teor de outros elementos, tais como: enxofre, potássio, magnésio, etc., indicando que essa ocorrência não é uniforme, com relação a todos os outros elementos do meio. Aumentos ligeiros do teor de nitratos e fosfatos, em águas de rios e lagos, levam, freqüentemente, a fenômenos de floração ou, de qualquer modo, à elevação do número de organismos de determinadas espécies em particular. Verifica-se, assim, a existência de estreita observação, por parte desses organismos, da já citada lei do mínimo 'ou lei de Liebig', segundo a qual a 


\begin{abstract}
deficiência em apenas um dos nutrientes exigidos pelo organismo determina uma diminuição da sua produtividade. As algas, 'inclusive cianobactérias', obedecem a essa lei, com relação ao nitrogênio, fósforo, enxofre, potássio, magnésio e outros elementos, segundo tem sido demonstrado através de experiências utilizando culturas das mesmas em laboratório. E o fato de, em águas naturais, somente a elevação do nitrogênio ou do fósforo produzir aumento do número de organismos, significa que essas águas contêm, normalmente, quantidades suficientes dos demais elementos, quer por serem mais freqüentes na natureza, quer por serem exigidos em menores quantidades. Realmente, sabe-se que, pelo menos em relação ao nitrogênio, que faz parte integrante da molécula de proteína, as exigências, por parte de um organismo, são proporcionais à concentração do elemento encontrado no próprio organismo. Assim é que, entre os mais exigentes desses seres, encontramse as cianobactérias causadoras de floração das águas: Microcystis aeruginosa, com 55,58\% de seu peso seco constituído de proteínas; Anabaena flos-aquae, com 60,56\% e Aphanizomenon flos-aquae com 62,80\%".
\end{abstract}




\subsection{CIANOBACTÉRIAS}

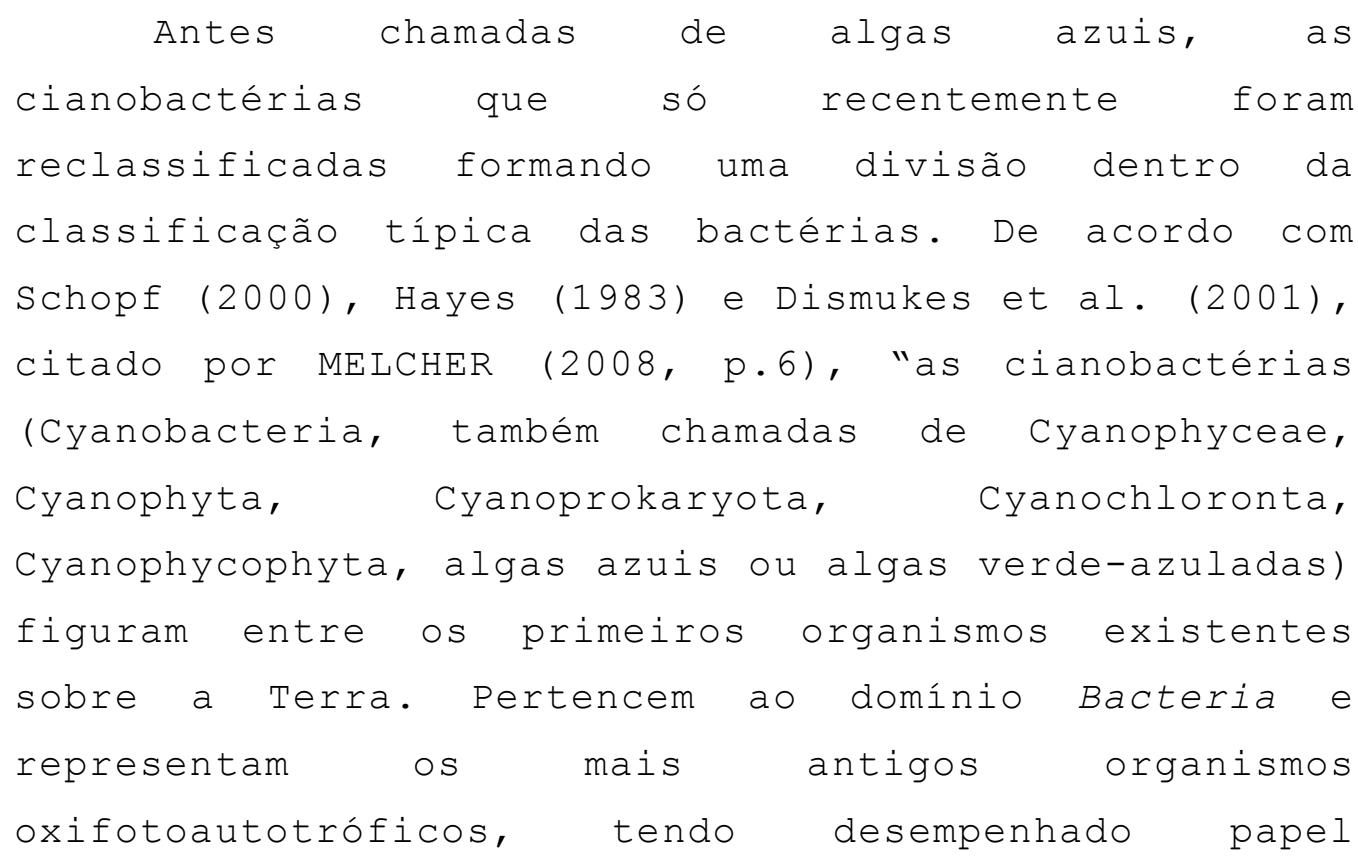
determinante na evolução da atmosfera oxidante de nosso planeta, bem como na constituição de deposições calcáreas na forma de estromatólitos". Segundo a Paleontologia, há fósseis antigos que indicam a presença destas no planeta Terra como sendo um dos primeiros seres vivos encontrados, e que podem ter contribuído na formação do oxigênio da atmosfera, pois segundo Charmichael (1994), citado por FUNASA (2003, p. 9), descreve que a cerca de 3,5 bilhões de anos, as cianobactérias provavelmente foram os primeiros produtores primários de matéria orgânica a liberarem oxigênio elementar na atmosfera primitiva. E ainda segundo FUNASA, são microrganismos aeróbicos fotoautotróficos que precisam só de água, dióxido de 
carbono, substâncias inorgânicas e luz para realizar a fotosíntese, e assim obter energia para o seu próprio metabolismo; entretanto a sua organização celular revela serem microrganismos procariontes, ou seja, muito semelhante bioquimicamente às bactérias, mas realizam fotossíntese como as algas, no entanto distinguem-se das algas por várias características, entre as quais se destaca a predominância da cor verde azulada, uma associação entre um pigmento azul, a ficocianina, e um pigmento verde, a clorofila. Estes pigmentos dentre outros são encontrados distribuidos por toda a massa protoplasmática de cada célula (BRANCO, 1986, p.73), diferentemente das algas que possuem cloroplastos em suas células, onde se localiza os diversos pigmentos. Uma das caracteristicas marcante das cianobactérias é a capacidade de crescimento nos mais diferentes meios, os mais favoráveis são ambientes de água doce, permitindo que a maioria das espécies cresçam melhor em águas neutroalcalinas (pH: 6-9), temperatura entre 15 a $30^{\circ} \mathrm{C}$ e preferencialmente em alta concentração de nutrientes como nitrogênio e fósforo. Estas condições de favorecimentos são muito encontradas em países tropicais como no Brasil. "São organismos de grande plasticidade ecológica, crescem em quase todos os ambientes aquáticos e terrestres e possuem distribuição em toda parte do planeta, sendo talvez os organismos fotossintéticos com maior amplitude de habitats (Badger et al. 2006, citado MELCHER, 2008, p. 6). 


\begin{abstract}
Segundo MELCHER (2008, p.6-7), elas "possuem mecanismos de proteção a elevada incidência de radiação solar nociva (UVB e UVC), ao mesmo tempo em que estão adaptadas a baixas intensidades luminosas. Seu modo de vida pode ser planctônico, bentônico, epi, peri ou endofítico, epi, peri ou endolítico, epi ou endozóico, subaéreo ou edáfico"...."o sucesso ecológico das cianobactérias decorre de sua longa história evolutiva e de suas características fisiológicas e estruturais. Entre estas, destaca-se a eficiente cinética de captação de carbono e nutrientes, a capacidade de fixação do nitrogênio atmosférico e a presença de aerótopos em muitas espécies planctônicas. A fixação do nitrogênio é realizada em condições anóxicas, seja em células especializadas (heterocitos) dotadas de paredes espessadas e fotossistema II (produtor de oxigênio) suprimido, seja através da separação temporal entre respiração e fixação de nitrogênio. A ausência de oxigênio é requisito para a atividade da nitrogenase, enzima que reduz o dinitrogênio atmosférico a amônia. os aerótopos, vesículas gasosas delimitadas por membrana protéica reunidas no interior da célula, conferem a inúmeras cianobactérias de vida aquática mobilidade vertical na coluna d'água".
\end{abstract}

A reprodução nunca se faz sexuadamente, mas assexuadamente e ocorre por simples divisão celular, pela produção de baeócitos ou exocitos (antigamente denominados de endósporos e exósporos, respectivamente), pela fragmentação do tricoma ou pela formação de hormocistos ou hormogônios 


\begin{abstract}
(fragmentos de tricoma móveis) (BRANCO, 1986 , p.74; e MELCHER, 2008 , p.10).
\end{abstract}

A parede celular permite considerar que as
cianobactérias sejam bactérias gram negativas, e
possuem envoltório mais espesso que o das demais
bactérias... $\quad$ Este envoltório está associado à proteção contra dessecamento, agentes antibacterianos (antibióticos, fagos, anticorpos, surfactantes etc) e predação por protozoários. Aliado a esta função de proteção, há ainda os exopolissacarídeos que exercem atividade aderente em substratos sólidos, floculam partículas de argila em águas turvas, aumentando a disponibilidade luminosa, captam elementos essenciais como ferro e cálcio e imobilizam metais deletérios aos organismos (De Phillipis \& Vicenzini 1998, 'citado por MELCHER, 2008, p.9'). Alguns gêneros de cianobactérias possuem a capacidade de produzir celulose. A função desta também se relaciona com a proteção contra o dessecamento e, além disso, possibilita a ligação com o organismo simbionte nas relações simbióticas e motilidade dos hormogônios (Nobles et al. 2001, 'citado por MELCHER, 2008 , p. $\left.9^{\prime}\right) .$. Certos grupos possuem células de resistência com parede espessada e grande acúmulo de nutrientes em seu interior, denominadas de acinetos. A produção de acinetos parece ser induzida principalmente por amplas flutuações de temperatura (Moore et al. 2005, 'citado por MELCHER, 2008, p.10').

Possuindo uma morfologia de muita diversidade, as cianobactérias ainda possuem hábito que abrange 
formas unicelulares, coloniais, filamentosas ou pseudoparenquimatosas, de dimensões micro a macroscópicas. Mesmo sem estruturas propulsoras como flagelos, algumas espécies ou gêneros "possuem a capacidade de movimento deslizante proporcionada pela extrusão de mucilagem ou pela atividade de estruturas especiais (pili do tipo 4 ou estruturas locomotoras semelhantes a cílios)" (Magar \& Pedley 2005, 'citado por MELCHER, 2008, p. 9').

\subsection{CIANOBACTÉRIAS COMO INDICADORES DE POLUIÇÃO}

Dentre as populações de organismos planctônicos (que flutuam na coluna d'água, sem ou com algum movimento próprio), a que mais se destaca na classificação ecológica dos corpos d'água é a do fitoplâncton que inclui as algas e as cianobactérias, justamente pela sua presença em todo tipo de água continental, além de incluir espécies tolerantes à presença de poluentes que respondem prontamente às mudanças ocorridas. Desse modo, registram melhor as variações da qualidade da água, funcionando como indicadores biológicos e permitindo o registro de alterações presentes e passadas, assim como o desequilíbrio existente (GENTIL, 2000).

A escolha de cianobactérias como indicador biológico de poluição aquática deve-se ao fato delas 
formarem juntamente com as algas a base do equilíbrio natural da cadeia alimentar em um ambiente de vida aquática e são organismos sensíveis à mudança ambiental. Dentre estes organismos existem espécies mais resistentes às mudanças e as menos resistentes, algumas destas espécies podem produzir toxinas mais potentes que serve de proteção no meio em que elas vivem, como as endotoxinas que causaram a morte de várias pessoas na clínica de hemodiálise em Caruaru, Pernambuco em 1996 e, além disso, possuem outros recursos de sobrevivência mais eficientes que outras que não se adaptam às mudanças. As mudanças ambientais podem ser percebidas através das cianobactérias, pois elas dominam ambientes eutróficos causando a supressão do crescimento de outros grupos fitoplanctônicos por excreção de certas substâncias, dentre estas, há as cianotoxinas como meio de defesa contra predadores zooplanctônicos (Codd et al, 1985 apud Souza et al 1998; citado por SZAJUBOK, 2000, p.67), tornando-se assim organismos potencialmente tóxicos, uma preocupação na área de saúde pública. Por não possuírem estas toxinas específicas, os outros grupos ficam vulneráveis aos ataques dos predadores na cadeia alimentar, os quais contribuem desta maneira para a diminuição de sua taxa de crescimento, e a essa diminuição os técnicos que realizam o monitoramento devem investigar mais detalhadamente as possíveis anomalias do manancial ou da água de captação. Mas há detalhes que merecem atenção, segundo pesquisas, o inibidor produzido pelas cianobactérias que impede a predação pelo zooplâncton não é o mesmo composto em relação a 
outras toxinas produzidas por elas mesmas, pois estudos através de experimentos realizados provaram que algumas cepas de Microcystis mesmo sendo capazes de matar mamíferos não impedem a alimentação em Daphinia (Lamper, 1987 apud Horne \& Goldman, 1994; citado por SzAJUBOK, 2000, p.68). Isto significa que mesmo considerando o fato de algumas cepas de cianobactérias produzirem cianotoxinas, ou seja, substâncias tóxicas prejudiciais aos mamíferos, não significa que estas mesmas substâncias destas cepas necessariamente são inibidoras aos predadores, pois as substâncias tóxicas a mamíferos da mesma cepa podem não serem as mesmas utilizadas contra predadores.

Outro problema, a cor e gosto da água, de
significado sanitário e que indica possíveis
alteraços no ambiente, e que pode estar relacionado
às cianobactérias, é a presença de geosmina e MIB
(metil-isoborneol) que confere odores de terra e mofo
(Horne \& Goldman, 1994 ; citados por szAJuok, 2000,
P.68). Há estudos controversos a esse respeito, um
demonstrou esta correlação em que lagos eutróficos as
cianobactérias são responsáveis por esta produção e
lagos oligotróficos os actinomicetos (fungos), outro
demonstrou que mesmo cianobactérias aderidas a
substratos localizados na zona litoral de lagos
pobres em nutrientes produziam odores de terra e mofo
(Persson, 1996; Izaguirre, 1992 apud persson, $1996 ;$
citados por szAJubok, 2000, p.68). De acordo com
estes estudos, considera-se que, tanto um como outro,
indica uma relação das cianobactérias com produção de


geosmina e MIB, e em havendo presença destas substâncias, seja na água de captação ou na água tratada, pode estar havendo presença de cianobactérias no manancial, ou até mesmo, ocorrendo florações destas neste corpo d’água.

Há dois elementos básicos importantes que permite considerar as cianobactérias como sendo indicadoras de poluição: fósforo e nitrogênio. Segundo BRANCO (1986, p.354) "Com relação ao fenômeno da poluição, o fósforo se apresenta como fator de maior importância, uma vez que, ainda que o suprimento de nitrogênio seja deficiente, este pode ser obtido a partir do ar atmosférico, sendo impossível exercer um controle sobre o teor presente nas águas; o fósforo sendo fornecido somente pelos despejos pode ser mais bem controlado, na prevenção contra a poluição".

De acordo com BRANCO (1986, p.353), a principal fonte de poluição se deve aos "esgotos domésticos, que levam, à água receptora, compostos orgânicos complexos que, através da oxidação biológica, contribuem para a formação de quantidades relativamente elevadas de nitratos e fosfatos como produtos finais. No caso do fósforo deve ser mencionado, ainda, o fato de que os esgotos vêm sendo, nos últimos anos, muito enriquecidos desse elemento, dado o emprego crescente de detergentes sintéticos nas atividades domésticas e industriais". 


\begin{abstract}
Atividades antrópicas que causam lançamento principalmente de esgoto doméstico nos mananciais provocam um aporte de macronutrientes como fósforo e nitrogênio, aumentando a concentração destes elementos químicos na água, consequentemente há um desequilíbrio no ambiente aquático propiciando as cianobactérias a um desenvolvimento maior em relação aos outros organismos devido ao seu poder de resistência a poluição ambiental e assim uma melhor absorção destes macronutrientes, trazendo como resposta, às agressões humanas contra o meio ambiente aquático, problemas graves de saúde e econômicos que se revertem contra o próprio homem. Um destes problemas, como conseqüência, são as toxinas que as cianobactérias liberam na água naturalmente, e que em um ambiente aquático muito eutrofizado ou demasiadamente poluído, o impacto é ainda maior, pois ocorre uma grande concentração de toxinas que podem ser liberadas na água decorrente das florações ou de uma multiplicação exagerada destes microrganismos, e que vai causar transtorno ao tratamento de água, pois a substância tóxica passa em forma de molécula pelo tratamento convencional.
\end{abstract}

Estudos sobre cianobactérias planctônicas em reservatórios do Alto Tietê, realizado por SANT'ANNA et al. (2007), demonstraram que estes microrganismos são indicadores adequados para se avaliar as condições ambientais aquáticas devido a relação da biodiversidade e distribuição das cianobactérias com cada reservatório, indicando uma característica particular do mesmo. 


\begin{abstract}
Pesquisas sobre cianobactérias em ambientes aquáticos têm demonstrado bons resultados, pois, de acordo com BRANCO (1986, p.74-75), uma das propriedades que elas possuem como heterocisto, uma célula diferenciada e especializada que possibilita às cianobactérias a fixar nitrogênio diretamente do ar, devido apresentar enzimas fixadoras de nitrogênio em seu meio, promovendo o desenvolvimento destas até mesmo "em ambientes pobres em nitrogênio, mas ricos em outros nutrientes", e desta forma as cianobactérias "assumem uma particular importância no estudo do fenômeno de eutrofização".
\end{abstract}

Além das cianobactérias, outros organismos do fitoplâncton constituem o primeiro elo da cadeia alimentar planctônica e, ao lado das macrófitas aquáticas, iniciam a fase biológica do ciclo dos nutrientes nos ambientes aquáticos, permitindo seu ingresso na cadeia alimentar. Produzem parte considerável do oxigênio atmosférico e oxigênio dissolvido na água, essencial aos organismos aeróbios, além de prover alimento para os consumidores primários incluindo protozoários, insetos, organismos do zooplâncton e peixes, servindo ainda aos organismos da cadeia detritívora tais como vírus, bactérias e fungos, tanto de substrato como de alimento. Dois terços da superfície terrestre são cobertos por água, e como o fitoplâncton é a comunidade das águas superficiais, torna-se responsável pela produção primária na maior parte da superfície terrestre (BEYRUTH, 1996). 


Apesar da pertinente constatação explicitada
por BEyruth em 1996 de que uma das maiores
dificuldades na utilização do fitoplâncton como
indicador de poluição é sua identificação em nível de
espécie, algumas empresas de saneamento como a
SABESP, apresentam seus resultados com a
identificaça apenas até o nível de gênero, o que
torna uma maior rapidez e agilidade na tomada de
decisões.

1.3 TOXINAS DE CIANOBACTÉRIAS E SAÚdE PÚBLICA

Águas contaminadas podem ser responsáveis pelo aparecimento de surtos de gastroenterites devido à ingestão de patógenos e também pelo crescimento exagerado de algas tóxicas.

As inúmeras florações de algas tóxicas em
lagos, rios e oceanos são responsáveis,
freqüentemente, pelo envenenamento e morte de animais
silvestres, domésticos e gado em vários paises.
(BEYRUTh et al, 1992)

Entende-se por algas tóxicas aquelas que produzem toxinas prejudiciais aos animais e ao homem. As cianobactérias, ou algas azuis, são grupos 
característicos de algas tóxicas. (MATSUZAKI et al, $2004)$

O primeiro relato de intoxicação de animais
causada por floração de cianobactérias é em 1878, no
lago Alexandrina, na Austrália, onde morreram
ovelhas, cavalos e cães (BRANCo, 1986).

E no Brasil, entre outros relatos de morte, por envenenamento de toxinas de cianobactérias, num surto de intoxicação humana resultante da presença de doses letais de hepatotoxinas (microcistinas) na água utilizada no sistema de hemodiálise, causou a morte de 76 pessoas imunodeprimidas e dependentes do tratamento numa clínica de hemodiálise em Caruaru (PE) (Pouria, et al., 1998 e Charmichael, et al., citado por MATSUZAKI, 2007, p.33). Este fato ocorreu em 1996 segundo Jochimsen et al., 1998 e Azevedo, et al., 2002, citado por MELCHER (2008, p.171).

A saúde animal e humana por muito tempo sofreu pela falta de informações mais detalhadas sobre intoxicações devido às cianobactérias, no entanto, atualmente, com os avanços tecnológicos e pesquisas científicas já é possível encontrar melhores soluções para o problema. Um dos estudos de grande interesse são os metabólitos secundários bioativos produzidos por esses microrganismos causadores de intoxicações por veiculação hídrica. Os metabólitos incluem dois tipos de toxinas, as citotoxinas e as biotoxinas. As biotoxinas são as de maior interesse que incluem os alcalóides neurotóxicos (anatoxina - a(s), 


\begin{abstract}
saxitoxinas), peptídeos cíclicos hepatotóxicos (microcistina e nodularina) e o alcalóide hepatotóxico (cylindrospermopsina). Dentre estas biotoxinas, destacam-se as microcistinas que podem ser produzidas tanto por cianobactérias filamentosas (Anabçaena, Oscillatoria, Nostoc, Hapalosiphon) quanto por coloniais (Microcystis); outras filamentosas como a Nodularia (de água salobra) e Cylindrospermopis raciborskii produzem a nodularina e cilindrospermopsina respectivamente. O gênero das Microcystis, produtor somente de microcistina, é um dos mais comuns formadores de florações ("blooms") encontrados em casos de envenenamento animal e humano. Este relacionamento entre as biotoxinas e as cianobactérias foi mencionado por Carmichael, 1996; Rinehart et al, 1994 apud Carmichael, 1996; citado por SZAJUBOK, 2000, p.69.
\end{abstract}

As intoxicações humanas por cianobactérias podem ocasionar problemas hepáticos (hepatotoxinas), neurológicos (neurotoxinas), distúrbios gastrointestinais e reações respiratórias e alérgicas. As neurotoxinas funcionam como bloqueadores musculares, entre outros fatores. As anatoxinas-a são neurotoxinas organofosfatadas que causam a hiper-salivação em animais e morte devido à inibição de acetilcolinesterase. As saxitoxinas (neurotoxinas carbamato-alcalóides) provocam envenenamento com paralisia, quando mariscos contaminados são consumidos. Já as hepatotoxinas incluem as microcistinas, nodularinas e cilindrospermopsinas, que produzem sintomas como 
fraqueza, palidez, extremidades frias, respiração ofegante, vômito e diarréia. Podem, também, ocasionar morte por parada respiratória e hemorragia hepática (Codd, 2000, citado por MATSUZAKI, 2007, p.32 e 33).

Os processos tradicionais de tratamento de água têm sido questionados quanto à remoção de microcistinas (Hoffman, 1976 e Himberg et al, 1989 apud Tsuji et al, 1997; citado por SZAJUBOK, 2000, p.72), pois somente a coagulação e filtração, importantes nestes processos, são ineficientes, servindo apenas para remover as células de cianobactérias, mas não as moléculas de cianotoxinas. Sendo assim, corre-se o risco, além de outros, de passar cianotoxinas pelo tratamento convencional, como as hepatotoxinas, envolvendo as microcistinas e nodularinas que podem ser potentes promotores de tumores (Carmichael, 1996; Tsuji, 1997; citado por SZAJUBOK, 2000, p.72), e mesmo sabendo da vantagem que estas podem ser facilmente decompostas pelo cloro com doses adequadas aplicadas na água bruta, mas não é a solução ideal, devido a provocar conseqüências mais complicadas, se, por exemplo, a aplicação de cloro for à pré-cloração, haverá mais liberação de toxinas na água com o rompimento das células de cianobactérias, e pela formação de trihalometanos (Oliver \& Schirdler, 1980; Yoo et al, 1995 apud Tsuji et al, 1997; citado por SZAJUBOK, 2000, p.72), também cancerígenos. Na desinfecção da água, o ideal é sempre aplicar cloro na pós-cloração, pois após o tratamento e na condição de uma água mais limpa, o cloro residual livre na água distribuída ao 
consumidor pode ser mais eficiente sem causar maiores conseqüências, ou seja, o objetivo é eliminar ou minimizar a níveis ínfimos a conseqüente produção de substâncias indesejáveis no produto final ao consumidor.

A exposição humana às cianotoxinas, em geral, pode ocorrer de diferentes maneiras, tais como: o contato primário com as águas contendo as toxinas, por inalação, ingestão oral e intravenosa (no tratamento por hemodiálise) e ingestão de animais, como peixes e moluscos, que se alimentaram continuamente de cianobactérias acumulando as toxinas em seus tecidos. (MATSUZAKI et al, 2004).

Segundo Carmichael \& Falconer, 1993 apud Falconer, 1996; citado por SZAJUBOK (2000, p.70), há casos de envenenamento de comunidades humanas por cianobactérias provenientes de reservatórios contendo florações destes organismos devido à aplicação de sulfato de cobre. A aplicação deste produto muito intensamente utilizado para eliminar as florações de cianobactérias, sem muito controle, pode acarretar em outros problemas mais sérios, por isso, atualmente, segundo normas vigentes, não se deve mais realizar aplicações de sulfato de cobre de forma indiscriminada, é preciso alguns critérios, e um destes, como exemplo, está na PORTARIA 518 DO MINISTÉRIO DA SAÚDE (2004), que menciona o artigo 19, segundo parágrafo, "É vedado o uso de algicidas para o controle do crescimento de cianobactérias ou qualquer intervenção no manancial que provoque a lise 


\begin{abstract}
das células desses microrganismos, quando a densidade das cianobactérias exceder 20.000 células/ml lou 2 $\mathrm{mm}^{3} / \mathrm{L}$ de biovolume), sob pena de comprometimento da avaliação de riscos à saúde associados às cianotoxinas". Esta lise artificial das células, especialmente, destes organismos em fase de florações, pode provocar a liberação de suas toxinas no meio, principalmente próximo a captação da ETA, e em conseqüência disto, há o risco de entrar na estação de tratamento de água uma concentração de cianotoxinas com alto poder de toxicidade, e o que se sabe, até o momento, ainda não há muitos processos com menos custo para a remoção destas moléculas tóxicas presentes na água. Como medida de remoção de toxinas na água que será distribuída ao consumo humano, empresas de saneamento, como a SABESP, tiveram que investir muito em processos mais eficientes como o de carvão ativado, pois este adsorve a molécula de cianotoxina presente na água. Outro processo de boa eficiência é o de ozonização.
\end{abstract}




\section{JUSTIFICATIVA}

Os fatos expostos acima deixam claro que a
preservaça da qualidade da água dos reservatórios do
Sistema Cantareira é fundamental para diminuir a
escassez de água potável na cidade de são Paulo muito
agravada nos períodos de estiagem que entre os anos
de 2002 e 2003, levou o sistema cantareira a
registrar os mais baixos níveis de armazenamento de
toda a sua história.
trabalho, de avaliar, com o auxilio de indicadores
bióticos e abióticos, a qualidade atual da água do
Sistema cantareira, reveste-se de extrema importância
e é plenamente justificada.




\section{OBJETIVO}

O presente trabalho tem como objetivo, avaliar,
através de variáveis biológicas (cianobactérias) em
conjunto com variáveis abióticas (temperatura da água,
cor, turbidez, pH, oxigênio dissolvido, fósforo e
nitrogênio), além do índice de estado trófico, as
condições em que se encontram as águas de captação que
alimentam quatro Estações de Tratamento de Água (Bragança
Paulista, Piracaia, Nazaré Paulista e Mairiporã)
relacionadas ao Sistema Cantareira no Estado de São
Paulo.




\section{MATERIAIS E MÉTODOS}

4.1 ÁREA DE ESTUDO

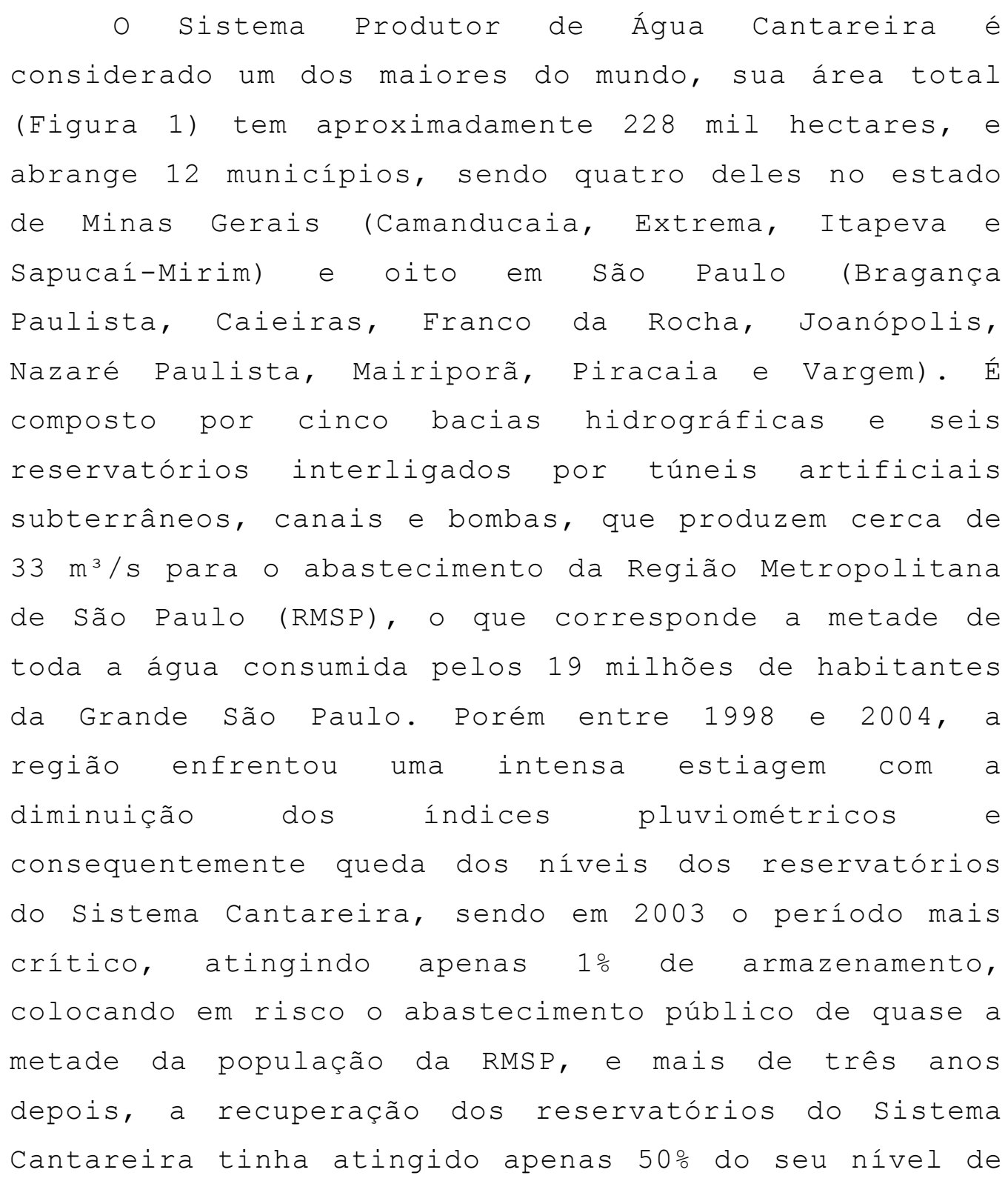


capacidade. Dados preocupantes de 2003 revelaram que grande parte do território das cincos bacias formadoras do sistema encontrava-se alterado por usos humanos, só 21\% da área do sistema continha áreas cobertas por vegetação, um recurso natural importante que possibilita a produção e purificação da água (WHATELY, 2006, p.6, 10, 11, 13, 14).

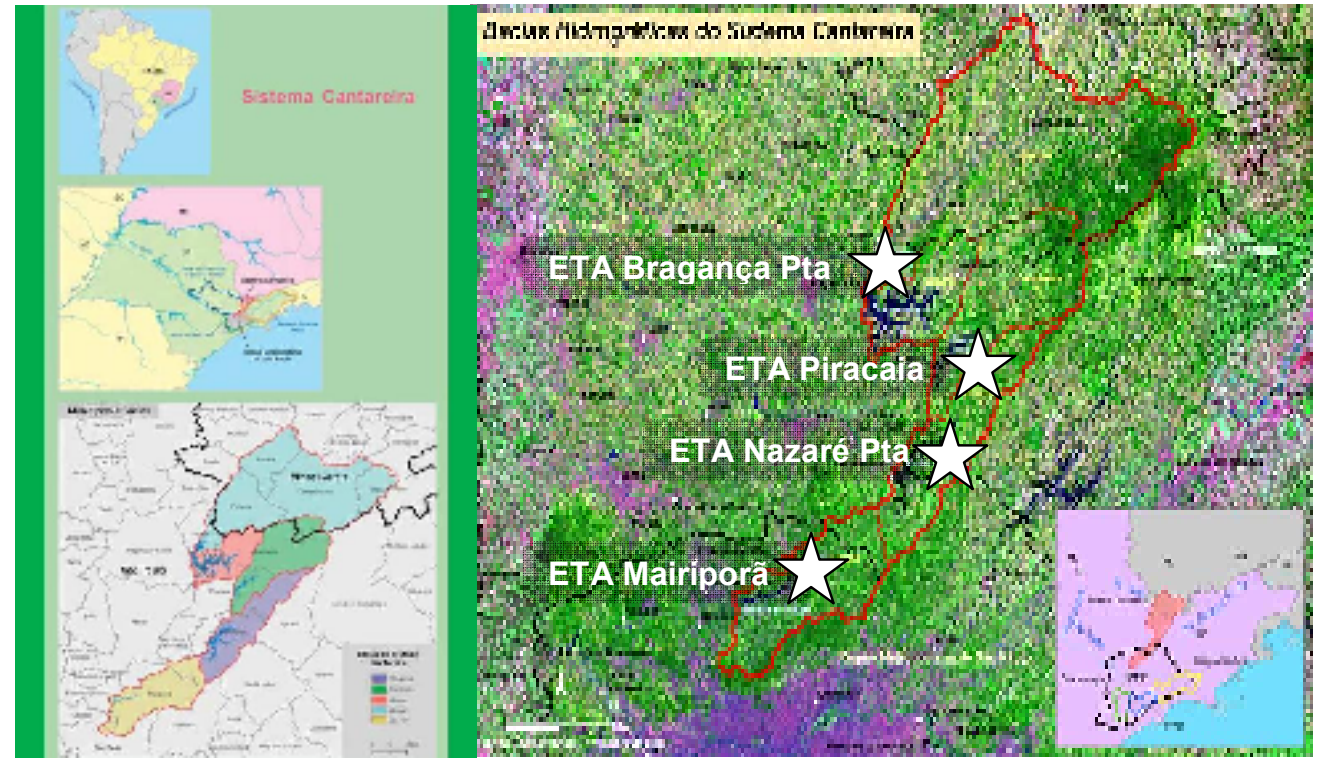

Fonte: Instituto Socioambiental, novembro de 2006

Figura 1 - Mapa da área de estudo.

Segundo Thomas (2006, p.2-3), compõem este Sistema, os reservatórios formados pelos barramentos nos rios Jaguari, Jacareí, Cachoeira e Atibainha, da bacia do rio Piracicaba, e pelo reservatório Paiva Castro, criado pelo barramento no rio Juqueri, da bacia do Alto Tietê. Os reservatórios formados pelos barramentos nos rios Jaguari, Jacareí, Cachoeira e Atibainha apresentam uma condição particular, pois constituem um sistema Equivalente que transpõe águas 
da bacia do rio Piracicaba para o reservatório Paiva Castro, localizado na bacia do Alto Tietê (Figura 2).

A concepção desse sistema data da década de 1960, sendo o Sistema construído em duas etapas: a primeira, iniciada em 1965 e concluída em 1975, envolveu a implantação dos reservatórios Cachoeira, Atibainha e Paiva Castro, enquanto a segunda etapa, iniciada em 1975 e concluída em 1981, envolveu a construção dos reservatórios interligados dos rios Jaguari e Jacareí. Os reservatórios nos rios Jaguari e Jacareí são ligados por um canal artificial, de pequena extensão, o qual possibilita ampliar a regularização das vazões provenientes do rio Jaguari. As interligações entre os reservatórios nos rios Jacareí e Cachoeira e entre os reservatórios nos rios Cachoeira e Atibainha são feitas por meio dos túneis 7 e 6, respectivamente. A reversão de vazões do Sistema Equivalente para o Paiva Castro é feita por meio do túnel 5, que conecta o Atibainha ao canal do Juqueri. Do Paiva Castro, as águas são aduzidas pela estação elevatória santa Inês até a estação de tratamento de água do Guaraú (ETA Guaraú). 


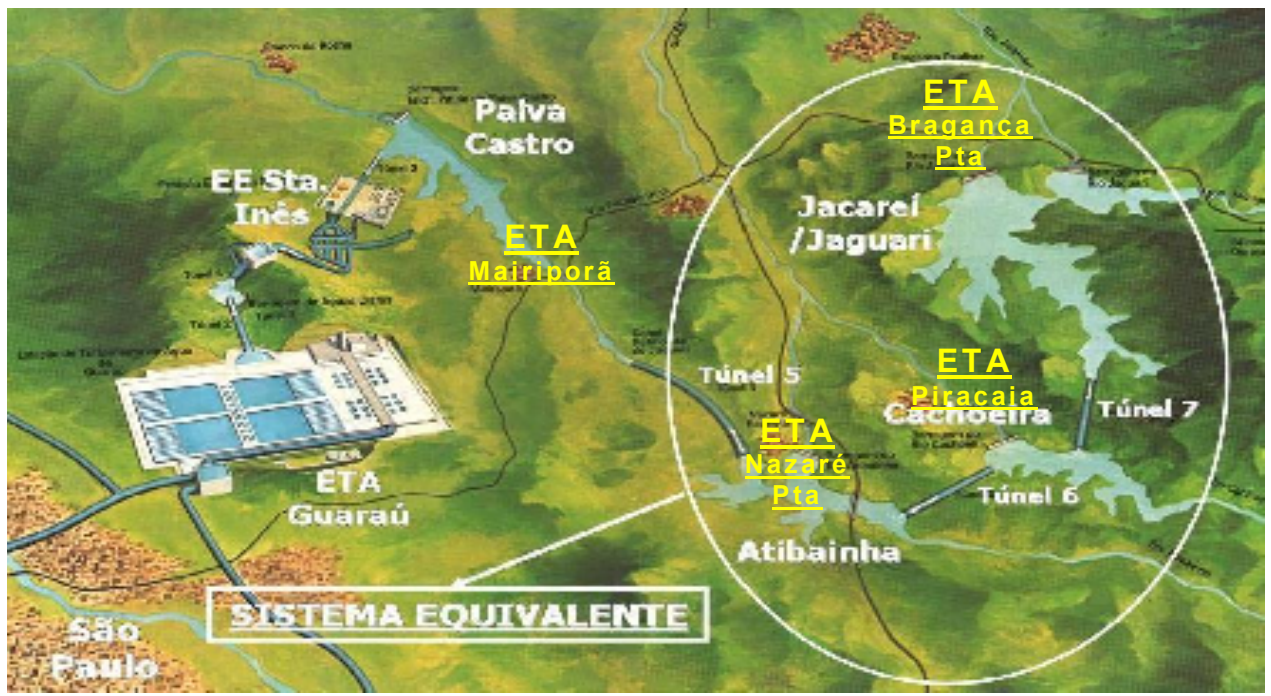

Fonte: Thomas, P. T. (2006)

Figura 2 - Esquema do Sistema Cantareira com suas represas e ETA's

Para produzir esta quantidade de água, o Sistema Cantareira (figura 3) faz a transposição entre duas bacias hidrográficas, importando água da Bacia do Piracicaba para a Bacia do Alto Tietê. A água produzida pelo Sistema Cantareira abastece 8,8 milhões de pessoas das zonas norte, central, parte da leste e oeste da capital e dos municípios de Franco da Rocha, Francisco Morato, Caieiras, Osasco, Carapicuíba e São Caetano do sul e parte dos municípios de Guarulhos, Barueri, Taboão da Serra e Santo André. 


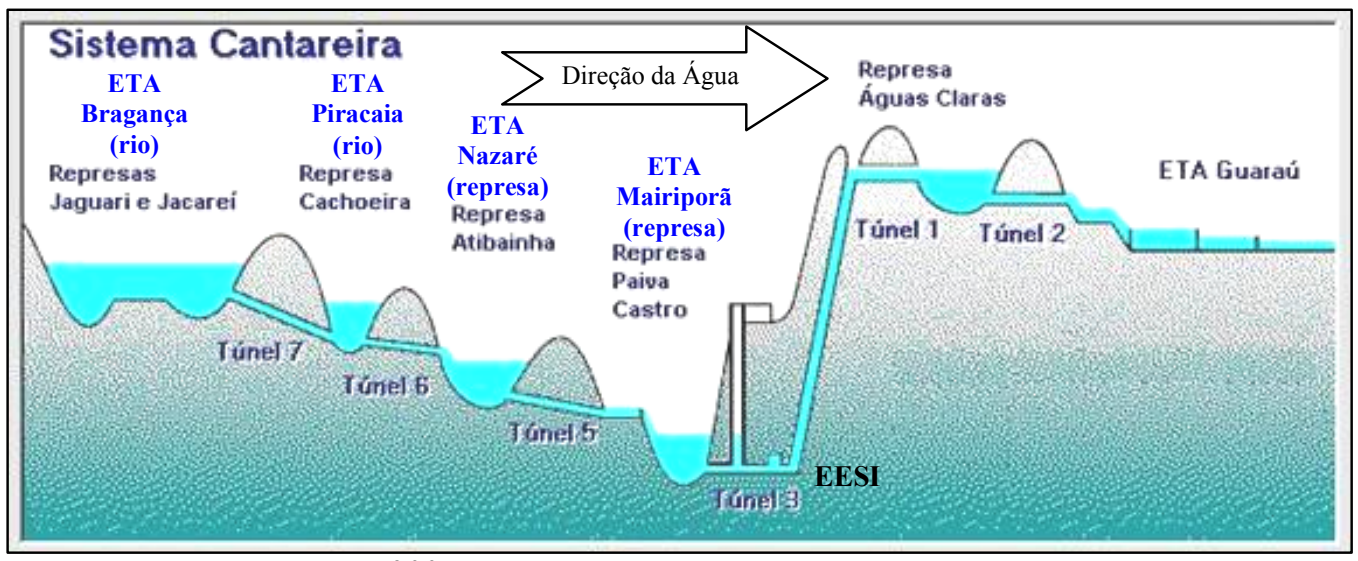

Fonte: Arce, M.G. J. (2005)

Figura 3 - Perfil esquemático ilustrativo do Sistema Cantareira.

A região do Sistema Cantareira, que já foi predominantemente rural, passou por intensas mudanças desde a construção dos reservatórios, que juntamente com as rodovias que cortam a região, ajudaram a modificar a configuração socioeconômica dos municípios e, conseqüentemente, o meio ambiente como um todo. (SABESP, 2010)

A preservação dos mananciais do Sistema Cantareira (zona norte de São Paulo) é de vital importância, pois represas como a Guarapiranga e Billings, sul da cidade de São Paulo, já estão extremamente eutrofizadas e há um custo muito alto para o tratamento dessas águas de modo a garantir uma qualidade segura para o consumo humano. Por outro lado, o Sistema Cantareira que é menos poluído e, portanto com menos custo em relação às conseqüências da poluição, abastece aproximadamente a metade da população da cidade. Nesse sentido, o presente 
trabalho visa, basicamente, demonstrar através de indicadores biológicos e abióticos a situação atual dos mananciais em questão, para alertar sobre possíveis mudanças ambientais antes que seu uso se torne inviável. o quadro 1, abaixo, mostra uma comparação entre os reservatórios do Sistema Cantareira e Guarapiranga-Billings.

Quadro 1 - Situação dos mananciais do Sistema Cantareira e Guarapiranga-Billings.

\begin{tabular}{|c|c|c|}
\hline & Sistema Cantareira & Guarapiranga-Billings \\
\hline $\begin{array}{l}\text { Disponibilidade } \\
\text { Hídrica (vazão) }\end{array}$ & $31,3 \mathrm{~m}^{3} / \mathrm{s}$ & $14,4 \mathrm{~m}^{3} / \mathrm{s}$ \\
\hline $\begin{array}{c}\text { Nível Trófico } \\
\text { (Fósforo Total - } \\
\text { 2003) }\end{array}$ & $\begin{array}{c}\text { 0,0222 mg/l } \\
\text { (Oligotrófico) } \\
\text { Tendendo a } \\
\text { eutrofização. }\end{array}$ & $\begin{array}{c}0,0575 \mathrm{mg} / 1 \\
\text { (Eutrófico) } \\
\text { Já está eutrofizado }\end{array}$ \\
\hline Problemas & $\begin{array}{l}\text { Água bruta tem } \\
\text { piorado com o aumento } \\
\text { da ocupação urbana. }\end{array}$ & $\begin{array}{l}\text { Ocupação urbana já } \\
\text { instalada. } \\
\text { Algas, gosto e odor. }\end{array}$ \\
\hline Ações & Preventiva & $\begin{array}{l}\text { Corretiva e } \\
\text { Preventiva }\end{array}$ \\
\hline
\end{tabular}

Fonte: PDAA-2006

Nota-se então que, no caso dos reservatórios do Sistema Cantareira, é imprescindível a implementação de medidas preventivas, no sentido de impedir 0 processo de eutrofização que uma vez iniciado é dificilmente reversível. 
4.2 obtenÇÃO DAS Amostras E LEVAntAmento DE DADOS

As amostras de água foram obtidas segundo rotina de coleta da SABESP, na superfície do ponto de captação das estações de tratamento de água nas cidades de Bragança Paulista, Piracaia, Nazaré Paulista e Mairiporã, nos anos de 2002 a 2008, obedecendo à seguinte periodicidade:

- Mensalmente: coleta para análises de fitoplâncton, temperatura, cor, pH e turbidez;

- Semestralmente: coleta para análises de fósforo, nitrogênio e oxigênio dissolvido.

- monitoramento das águas de captação (água bruta) para abastecimento público destas cidades, nas estações de tratamento de água, é realizado pela SABESP através dos seguintes pontos de coleta ou de amostragem:

- $\quad$ Ponto 33B-1 - rio Jaguari (ETA-Bragança Paulista);

- Ponto 42B-1 - rio Cachoeira (ETA-Piracaia);

- Ponto 41B-1 - represa Atibainha (ETA-Nazaré Paulista);

- Ponto 19B-1 - represa Paiva Castro (ETA-Mairiporã) .

As informações constam de relatórios elaborados e disponibilizados pela própria SABESP. O levantamento bibliográfico complementar foi realizado por meio de consulta à biblioteca da Faculdade de Saúde Pública da Universidade de São Paulo e as bases eletrônicas de dados. 
4.3 PARÂMETROS FíSICOS DA ÁGUA

Consideraram-se, neste estudo, as águas de
captação como sendo de classe II para água doce
$($ CONAMA-357/05).

4.3.1 Cor

A cor aparente da água foi medida por comparação visual em laboratório, utilizando-se um colorímetro, de acordo com AWWA (1998).

4.3.2 Turbidez

A turbidez da água foi medida em laboratório, utilizando-se um turbidímetro marca $\mathrm{HACH}$, modelo $2100 \mathrm{~N}$, de acordo com AWWA (1998). 
4.3.3 Temperatura

A temperatura da água foi medida em campo utilizando-se um termômetro de mercúrio, graduado em graus Celsius.

Para este estudo as temperaturas das amostras de água de captação foram obtidas no momento da coleta.

4.4 PARÂMETROS QUÍMICOS DA ÁGUA

Consideraram-se as águas de captação para este estudo como sendo de água doce - classe II, segundo CONAMA-357/05.

4.4.1 Oxigênio Dissolvido

Os níveis de oxigênio dissolvido na água foram medidos pelo método Winckler modificado pela azida sódica, conforme preconizado por AWWA (1998). 
4.4.2 Nitrogênio

A concentração de nitrogênio na água foi medida pelo método de cromatografia de ìons de acordo com AWWA (1998).

4.4.3 Fósforo

A concentração de fósforo na água foi medida pelo método do Cloreto Estanoso, de acordo com AWWA (1998) .

4.4.4 Potencial Hidrogeniônico

O potencial hidrogeniônico (pH) da água foi medido em laboratório, utilizando-se um medidor de pH marca Thermoorion, modelo: 720 A. 


\subsection{PARÂMETRO BIOLÓGICO}

Como parâmetro, nas últimas décadas, as
cianobactérias adquiriram tanta importância que já
foram inclusas na atual portaria-518/04 do Ministério
da saúde a partir da última revisão da antiga
portaria-36. As autoridades competentes das áreas
envolvendo saúde, saneamento e meio ambiente
determinaram os seguintes limites:

a) Monitoramento mensal quando o número de cianobactérias não exceder 10.000 cél/mL no ponto de captação do manancial;

b) Monitoramento semanal quando o número de cianobactérias exceder 10.000 cél/mL no ponto de captação do manancial;

c) Monitoramento semanal seguido de teste para cianotoxinas na saída do tratamento e nas entradas (hidrômetros) das clínicas de hemodiálise e indústrias de injetáveis quando o número de cianobactérias exceder 20.000 cél/mL no ponto de captação do manancial. A portaria 518/04 menciona 3 cianotoxinas: cilindrospermopsinas, saxitoxinas e microcistinas. Para o teste de cianotoxinas a portaria recomenda a quantificação de cilindrospermopsinas e saxitoxinas e obriga a 
quantificação de microcistina que tem como limite máximo permissível igual a $1 \mu \mathrm{g} / \mathrm{L}$ para água potável.

As amostras de água de captação para
cianobactérias foram coletadas em recipientes de 5
litros e processadas de acordo com BRANco (1986,
p.203-204) que utiliza o método de sedgwck-Rafter
para concentração e posterior identificação e
contagem em câmara de sedgwick-Rafter, conforme
preconiza a AWWA (1998).

O ensaio hidrobiológico na SABESP, para monitoramento das estações de tratamento de água, é realizado em contagem completa, ou seja, contam-se todos os grupos de algas, inclusive cianobactérias e zooplâncton.

Parcialmente, o monitoramento das águas
destinadas ao consumo humano no setor de
hidrobiologia, para efeito de cumprimento de normas e
da vigilância sanitária, as cianobactérias são
expressas em número de células/mL de acordo com a
PoRTARIA $518 / 04$ e conAmA $357 / 05$, pois, neste caso da
SABESP, a contagem completa é calculada em número de
Organismos/mL e UPA/mL, então, no final do cálculo, é
realizado as conversões através da média obtida sobre
o número de células de cianobactérias, sejam em
formas de colônia ou de filamento.




\section{VARIÁVEIS}

5.1 VARIÁVEIS BIOLÓGICAS

5.1.1 Cianobactérias

Neste estudo as cianobactérias são importantes como a variável principal, pois são microrganismos que estão sendo cada vez mais envolvidos em situações de saúde pública e também, como um bom indicador de mudanças ambientais em determinados corpos d’água.

5.1.2 Algas Verdes

As algas verdes ou Chlorophytas formam um grupo de algas que convivem em equilíbrio com as cianobactérias em ambientes naturais, mas podem sofrer com as mudanças climáticas provocadas por um desequilibrio seja de ordem natural ou de ordem artificial ou antrópica.

Neste caso, as algas verdes são utilizadas para efeito de comparação com as cianobactérias. 


\subsection{VARIÁVEIS AMBIENTAIS}

\subsubsection{Temperatura}

Fator importante que influencia o crescimento e a resposta do fitoplâncton, pois segundo a Lei Geral Q10, os processos metabólicos dobram a cada aumento de $10^{\circ} \mathrm{C}$. A taxa de fotossíntese de um determinado organismo aumenta proporcionalmente a intensidade luminosa, mas quando atinge o máximo numa determinada temperatura, ela permanece constante, mas se, por exemplo, a temperatura aumentar o dobro, a taxa de fotossíntese aumenta o dobro também, ou seja, a taxa de fotossíntese depende da diminuição ou aumento da temperatura mesmo estando numa mesma intensidade de luz (Tundisi, 2008, p.175).

\subsubsection{Fósforo Total}

A importância do fósforo está relacionada aos processos fundamentais do metabolismo dos seres vivos, pois forma uma fração essencial da molécula de ATP para armazenamento de energia e estruturação da membrana celular através dos fosfolipídios. É um 
elemento químico em que na maioria das águas continentais constitui-se no principal fator limitante de sua produtividade, e também é apontado como o principal responsável pela eutrofização artificial destes ecossistemas (ESTEVES, 1998, p.223).

5.2 .3 Nitrogênio

Segundo ESTEVES (1998, p. 204), o nitrogênio, "dentre as diferentes formas, o nitrato, juntamente com o íon amônio, assumem grande importância nos ecossistemas aquáticos, uma vez que representam as principais fontes de nitrogênio para os produtores primários".

Neste estudo o nitrogênio na forma de nitrato $\left(\mathrm{NO}_{3}{ }^{-}\right)$é utilizado pelo "fato do nitrato constituirse, na maioria dos casos, como a principal fonte de nitrogênio para os vegetais aquáticos", sendo que o nitrogênio amoniacal apresenta concentrações muito baixa nas camadas onde se encontra o fitoplâncton, devido a sua absorção ser realizada energeticamente mais fácil pelos organismos produtores, ESTEVES $(1998$, p. 206). 


\begin{abstract}
o nitrogênio amoniacal presente em corpos d'água pode estar relacionado a contaminações recentes por esgotos domésticos.
\end{abstract}

5.2.4 Oxigênio Dissolvido

\begin{abstract}
O oxigênio dissolvido na água é um gás que tem sua importância na dinâmica e na caracterização de ecossistemas aquáticos, e suas principais fontes são a atmosfera e a fotossintese, ou seja, é um gás captado da atmosfera para a água que se soma a produção de oxigênio liberado pela reação da fotossíntese para o meio aquático, mas ao mesmo tempo de sua captação e produção está ocorrendo a sua perda para a própria atmosfera, e na decomposição de matéria orgânica (oxidação), para a respiração de organismos aquáticos e oxidação de íons metálicos como o ferro e o manganês. Além disso, como qualquer outro gás, a solubilidade do oxigênio depende de dois fatores principais: temperatura e pressão. Exemplo: a temperatura em torno de $30^{\circ} \mathrm{C}$ e pressão de $760 \mathrm{mmHg}$, solubilizam-se uma quantidade de 7,59 mg de oxigênio por litro de água, enquanto que na mesma pressão e temperatura em torno de $0^{\circ} \mathrm{C}$, solubiliza-se uma quantidade de $14,60 \mathrm{mg}$ de oxigênio por litro de água. Esta relação entre oxigênio dissolvido e os dois fatores, temperatura e pressão, permite a seguinte constatação: a saturação do oxigênio é a quantidade
\end{abstract}


máxima de oxigênio que pode ser dissolvida na água dependendo basicamente de uma determinada pressão e temperatura (ESTEVES, 1998, p.146).

5.2.5 Cor, Turbidez e pH

a) $\operatorname{Cor}$

A cor da água: presença de substâncias pigmentadas em solução ou dispersão coloidal (BRANCO, $1986, \mathrm{p} .262)$.

b) Turbidez

A turbidez: presença de partículas em suspensão que podem ou não ser coloridas (BRANCO, 1986, p.262).

Observação: Com relação à cor e a turbidez, há microrganismos que podem ser causadores destas ocorrências nas águas dos mananciais. Exemplo: algas, cianobactérias ou outros microrganismos.

c) $\mathrm{pH}$

A importância do pH da água deve-se basicamente a sua influência sobre muitos processos químicos e biológicos dos corpos d'água, porém esta variável pode também sofrer variações causadas pela respiração e fotossíntese de algas em águas eutróficas (Chapman \& Kimstach, 1996, citado por MATSUZAKI, 2007, p.77$78)$. 


\title{
5.3 ÍNDICE DE ESTADO TRÓFICO (IET)
}

\author{
Segundo CETESB (Relatório de qualidade das \\ Águas Interiores do Estado de São Paulo - 2007-Anexo- \\ III) : \\ "O Índice do Estado Trófico tem por finalidade \\ classificar corpos d'água em diferentes graus de \\ trofia, ou seja, avalia a qualidade da água quanto ao \\ enriquecimento por nutrientes e seu efeito \\ relacionado ao crescimento excessivo das algas ou ao \\ aumento da infestação de macrófitas aquáticas.
}

Das três variáveis citadas para o cálculo do Índice do Estado Trófico, foram aplicadas apenas duas: clorofila a e fósforo total, uma vez que os valores de transparência muitas vezes não são representativos do estado de trofia, pois esta pode ser afetada pela elevada turbidez decorrente de material mineral em suspensão e não apenas pela densidade de organismos planctônicos, além de muitas vezes não se dispor desses dados. Dessa forma, não será considerado o cálculo do índice de transparência em reservatórios e rios do Estado de São Paulo.

Nesse índice, os resultados correspondentes ao fósforo, IET(P), devem ser entendidos como uma medida do potencial de eutrofização, já que este nutriente atua como o agente causador do processo. A avaliação correspondente à clorofila a, IET(CL), por sua vez, deve ser considerada como uma medida da resposta do corpo hídrico ao agente causador, indicando de forma 
adequada o nível de crescimento de algas que tem lugar em suas águas. Assim, o índice médio engloba, de forma satisfatória, a causa e o efeito do processo. Deve-se ter em conta que num corpo hídrico, em que o processo de eutrofização encontra-se plenamente estabelecido, o estado trófico determinado pelo índice da clorofila a certamente coincidirá com o estado trófico determinado pelo índice do fósforo.

Já nos corpos hídricos em que o processo esteja limitado por fatores ambientais, como a temperatura da água ou a baixa transparência, o índice relativo à clorofila a irá refletir esse fato, classificando o estado trófico em um nível inferior àquele determinado pelo índice do fósforo. Além disso, caso sejam aplicados algicidas, a conseqüente diminuição das concentrações de clorofila a resultará em uma redução na classificação obtida a partir do seu índice.

o Índice do Estado Trófico apresentado e utilizado no cálculo do IVA, será composto pelo Índice do Estado Trófico para o fósforo - IET(PT) e o Índice do Estado Trófico para a clorofila a IET(CL), modificados por LAMPARELLI (2004), sendo estabelecidos para ambientes lóticos, segundo as equações :

\section{- Rios}

$$
\begin{aligned}
& \operatorname{IET}(\mathrm{CL})=10 x(6-((-0,7-0,6 x(\ln \mathrm{CL})) / \ln 2))-20 \\
& \operatorname{IET}(\mathrm{PT})=10 x(6-((0,42-0,36 x(\ln \mathrm{PT})) / \ln 2))-20
\end{aligned}
$$




\section{- Reservatórios}

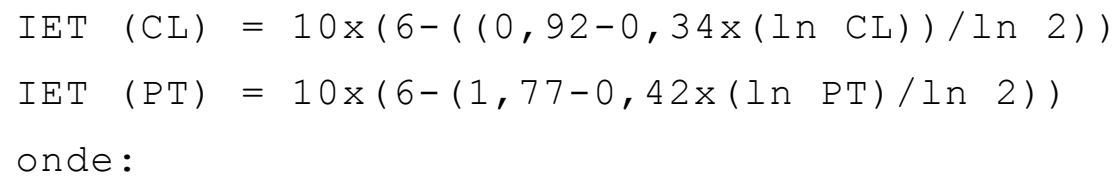

PT: concentração de fósforo total medida à superfície da água, em $\mu \mathrm{g} . \mathrm{L}-1$;

CL: concentração de clorofila a medida à superfície da água, em $\mu \mathrm{g} . \mathrm{L}-1$;

ln: logaritmo natural.

Nos meses em que estejam disponíveis dados de ambas variáveis, o resultado apresentado nas tabelas do IET será a média aritmética simples dos índices relativos ao fósforo total e a clorofila a, segundo a equação:

$$
\operatorname{IET}=[\operatorname{IET}(\mathrm{PT})+\operatorname{IET}(\mathrm{CL})] / 2
$$

$\mathrm{Na}$ interpretação dos resultados, os pontos serão classificados conforme os resultados obtidos para o IET anual. Assim, para cada ponto, serão utilizadas as médias geométricas das concentrações de fósforo total e clorofila a para cálculo do IET(PT) e IET(CL) anual, sendo o IET final resultante da média aritmética simples dos índices anuais relativos ao fósforo total e a clorofila a.

Em virtude da variabilidade sazonal dos processos ambientais que têm influência sobre o grau de eutrofização de um corpo hídrico, esse processo pode apresentar variações no decorrer do ano, havendo épocas em que se desenvolve de forma mais intensa e outras em que pode ser mais limitado. Em geral, no início da primavera, com o aumento da temperatura da 
água, maior disponibilidade de nutrientes e condições propícias de penetração de luz na água, é comum observar-se um incremento do processo, após o período de inverno, em que se mostra menos intenso. Nesse sentido, a determinação do grau de eutrofização médio anual de um corpo hídrico pode não identificar, de forma explícita, as variações que ocorreram ao longo do período anual, assim também serão apresentados os resultados mensais para cada ponto amostral.

No caso de não haver resultados para o fósforo total ou para a clorofila a, o índice será calculado com a variável disponível e considerado equivalente ao IET, devendo, apenas, constar uma observação junto ao resultado, informando que apenas uma das variáveis foi utilizada".

Como respostas aos resultados correspondentes ao fósforo, as algas podem servir como indicadores de poluição quando ocorrem suas florações ou sua diminuição, afetando o ambiente aquático e conseqüentemente a qualidade da água.

Para este estudo do estado trófico, clorofila a e disco de Secchi (S), como constam na tabela 1 e tabela 2, não são aplicados por ausência de resultados nestes pontos de amostragens, utilizandose apenas como medida do potencial de eutrofização o fósforo total (P): 
Tabela 1 - Classificação do Estado Trófico para rios segundo Índice de Carlson Modificado por Lamparelli $(2004)$.

\begin{tabular}{lcccc}
\hline $\begin{array}{l}\text { Categoria } \\
\text { (estado trófico) }\end{array}$ & Ponderação & $\begin{array}{c}\text { Secchi } \\
\mathrm{S}(\mathrm{m})\end{array}$ & $\begin{array}{c}\text { P-total } \\
\mathrm{P}\left(\mathrm{mg} \cdot \mathrm{L}^{-1}\right)\end{array}$ & $\begin{array}{c}\text { Clorofila a } \\
\left(\mathrm{mg} \cdot \mathrm{m}^{-3}\right)\end{array}$ \\
\hline Ultraoligotrófico & IET $\leq 47$ & - & $\mathrm{P} \leq 0,013$ & $\mathrm{CL} \leq 0,74$ \\
\hline Oligotrófico & $47<$ IET $\leq 52$ & - & $0,013<\mathrm{P} \leq 0,035$ & $0,74<\mathrm{CL} \leq 1,31$ \\
\hline Mesotrófico & $52<$ IET $\leq 59$ & - & $0,035<\mathrm{P} \leq 0,137$ & $1,31<\mathrm{CL} \leq 2,96$ \\
\hline Eutrófico & $59<$ IET $\leq 63$ & - & $0,137<\mathrm{P} \leq 0,296$ & $2,96<\mathrm{CL} \leq 4,70$ \\
\hline Supereutrófico & $63<$ IET $\leq 67$ & - & $0,296<\mathrm{P} \leq 0,640$ & $4,70<\mathrm{CL} \leq 7,46$ \\
\hline Hipereutrófico & IET 67 & - & $0,640<\mathrm{P}$ & $7,46<\mathrm{CL}$ \\
\hline
\end{tabular}

Fonte: cetesb-2007

Tabela 2 - Classificação do Estado Trófico para reservatórios segundo Índice de Carlson Modificado por Lamparelli (2004).

\begin{tabular}{lcccc}
\hline $\begin{array}{l}\text { Categoria } \\
\text { (estado trófico) }\end{array}$ & Ponderação & $\begin{array}{c}\text { Secchi } \\
\mathrm{S}(\mathrm{m})\end{array}$ & $\begin{array}{c}\text { P-total } \\
\mathrm{P}\left(\mathrm{mg} \cdot \mathrm{L}^{-1}\right)\end{array}$ & $\begin{array}{c}\text { Clorofila a } \\
\left(\mathrm{mg} \cdot \mathrm{m}^{-3}\right)\end{array}$ \\
\hline Ultraoligotrófico & $\mathrm{IET} \leq 47$ & $\mathrm{~S} \geq 2,4$ & $\mathrm{P} \leq 0,008$ & $\mathrm{CL} \leq 1,17$ \\
\hline Oligotrófico & $47<\mathrm{IET} \leq 52$ & $2,4>\mathrm{S} \geq 1,7$ & $0,008<\mathrm{P} \leq 0,019$ & $1,17<\mathrm{CL} \leq 3,24$ \\
\hline Mesotrófico & $52<\mathrm{IET} \leq 59$ & $1,7>\mathrm{S} \geq 1,1$ & $0,019<\mathrm{P} \leq 0,052$ & $3,24<\mathrm{CL} \leq 11,03$ \\
\hline Eutrófico & $59<\mathrm{IET} \leq 63$ & $1,1>\mathrm{S} \geq 0,8$ & $0,052<\mathrm{P} \leq 0,120$ & $11,03<\mathrm{CL} \leq 30,55$ \\
\hline Supereutrófico & $63<\mathrm{IET} \leq 67$ & $0,8>\mathrm{S} \geq 0,6$ & $0,120<\mathrm{P} \leq 0,133$ & $30,55<\mathrm{CL} \leq 69,05$ \\
\hline Hipereutrófico & IET 67 & $0,6>\mathrm{S}$ & $0,233<\mathrm{P}$ & $69,05<\mathrm{CL}$
\end{tabular}




\section{RESULTADOS}

\subsection{VARIÁVEIS BIOLÓGICAS}

\subsubsection{Cianobactérias e Algas Verdes}

Em relação aos resultados das variáveis biológicas das águas de captação das quatro estações de tratamento para o período de 2002 a 2008, as cianobactérias e as algas verdes foram representadas graficamente de acordo com a direção da água do Sistema Cantareira (figura 3):

$1^{a}$ ETA (Bragança Paulista) - Ponto de coleta: 33B1 - Rio Jaguari:

- Cianobactérias

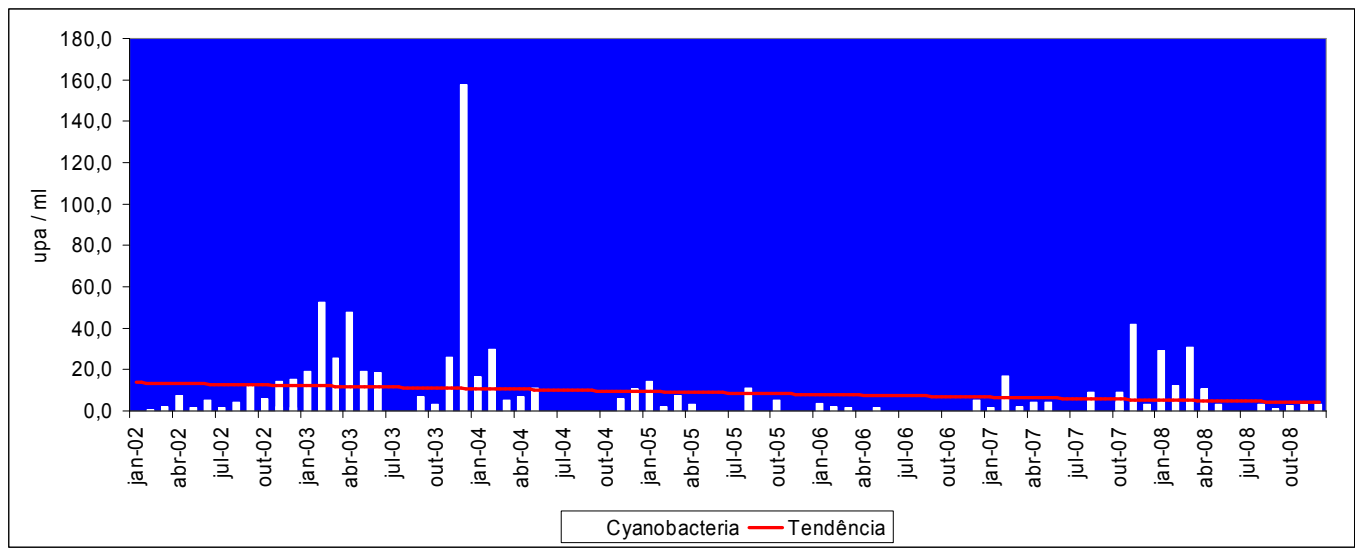

Fonte dos dados: Sabesp (Controle Sanitário Norte - mnec - 2008)

Figura 4 - Cianobactérias na água de captação da ETA de Bragança Paulista.

- Algas Verdes

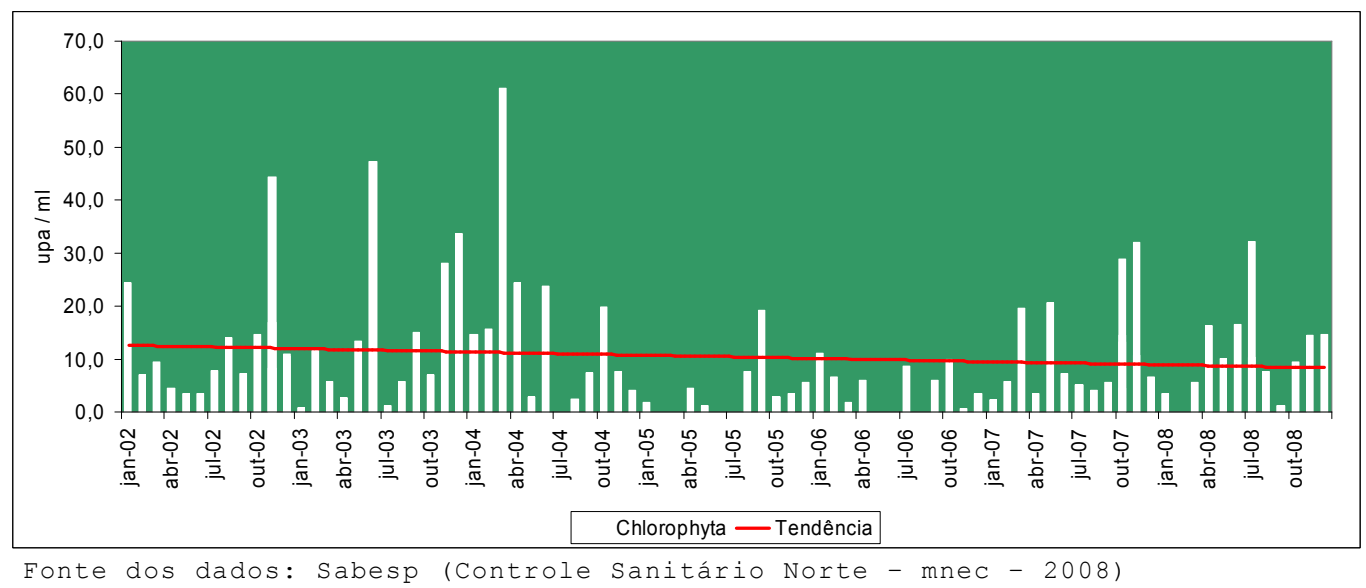

Figura 5 - Algas Verdes na água de captação da ETA de Bragança Paulista. 
$2^{a}$ ETA (Piracaia) - Ponto de coleta: 42B1 - Rio Cachoeira:

- Cianobactérias

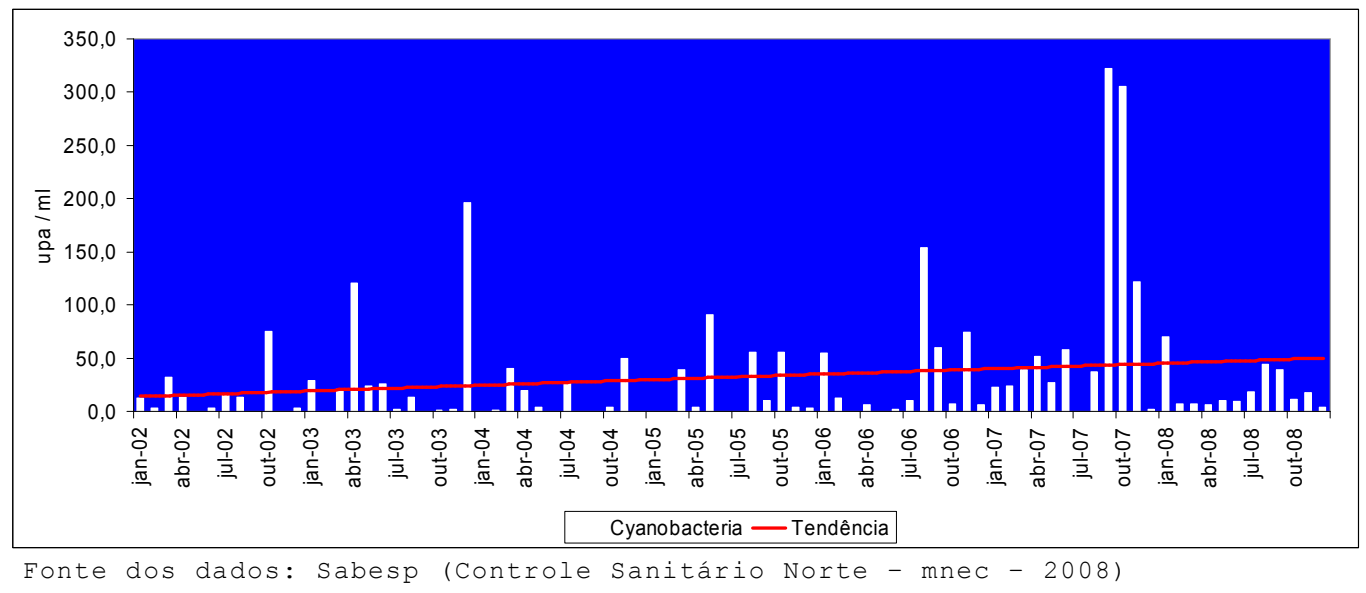

Figura 6 - Cianobactérias na água de captação da ETA de Piracaia.

- Algas Verdes

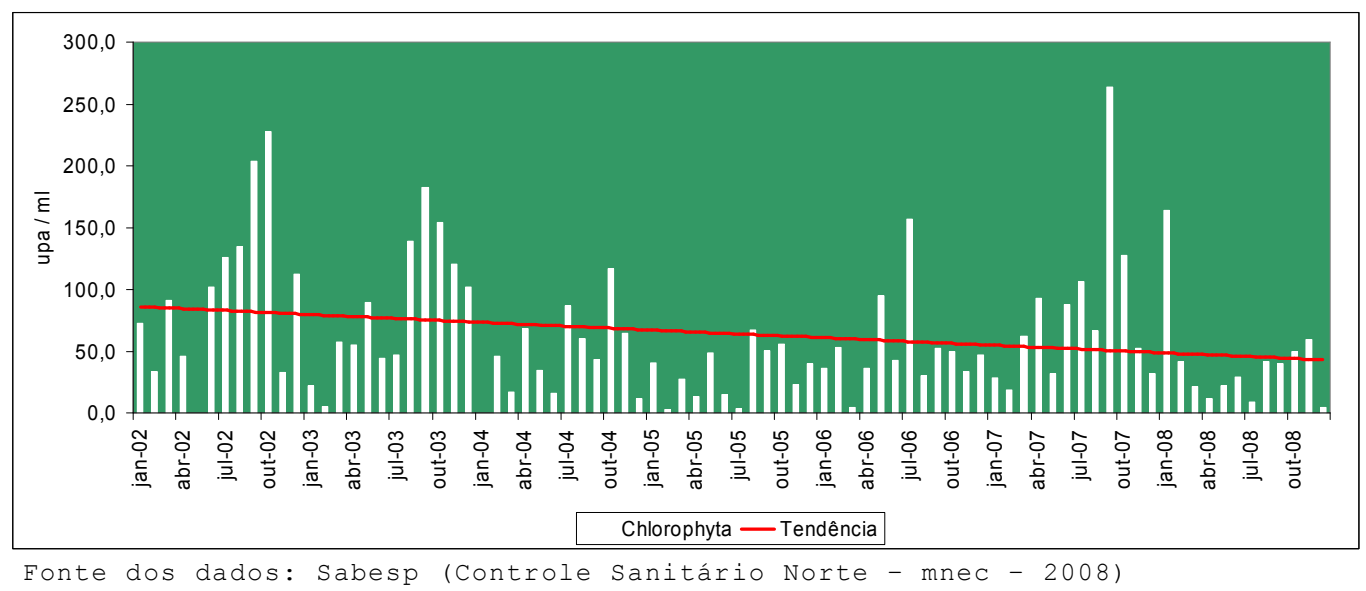

Figura 7 - Algas Verdes na água de captação da ETA de Piracaia. 
$3^{a}$ ETA (Nazaré Paulista) - Ponto de coleta:41B1 Represa Atibainha:

- Cianobactérias

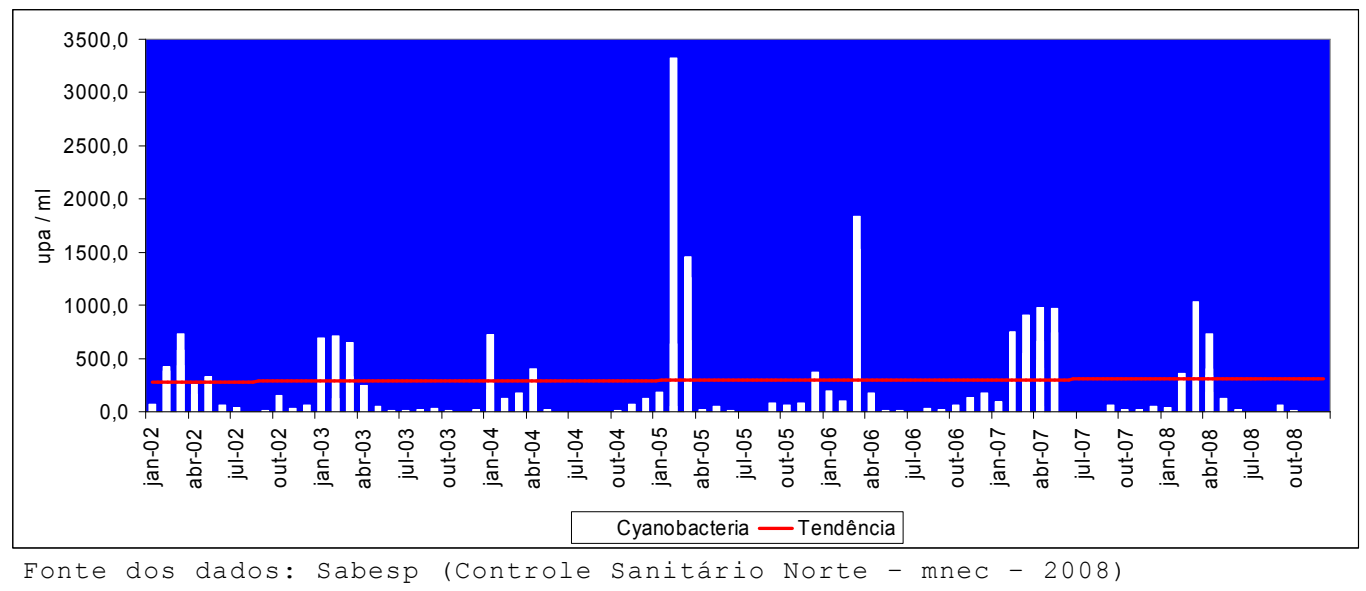

Figura 8 - Cianobactérias na água de captação da ETA de Nazaré Paulista.

- Algas Verdes

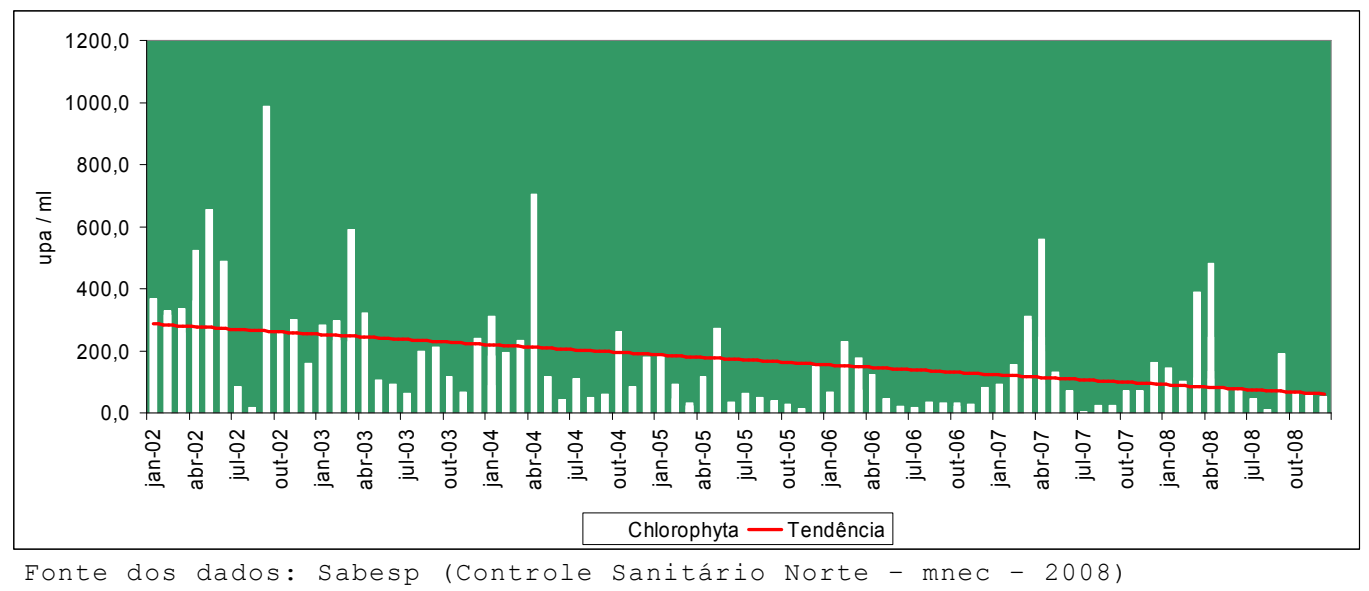

Figura 9 - Algas Verdes na água de captação da ETA de Nazaré Paulista. 
$4^{\text {a }}$ ETA (Mairiporã) - Ponto de coleta: 19B1 - Represa Paiva Castro-Rio Juqueri:

- Cianobactérias

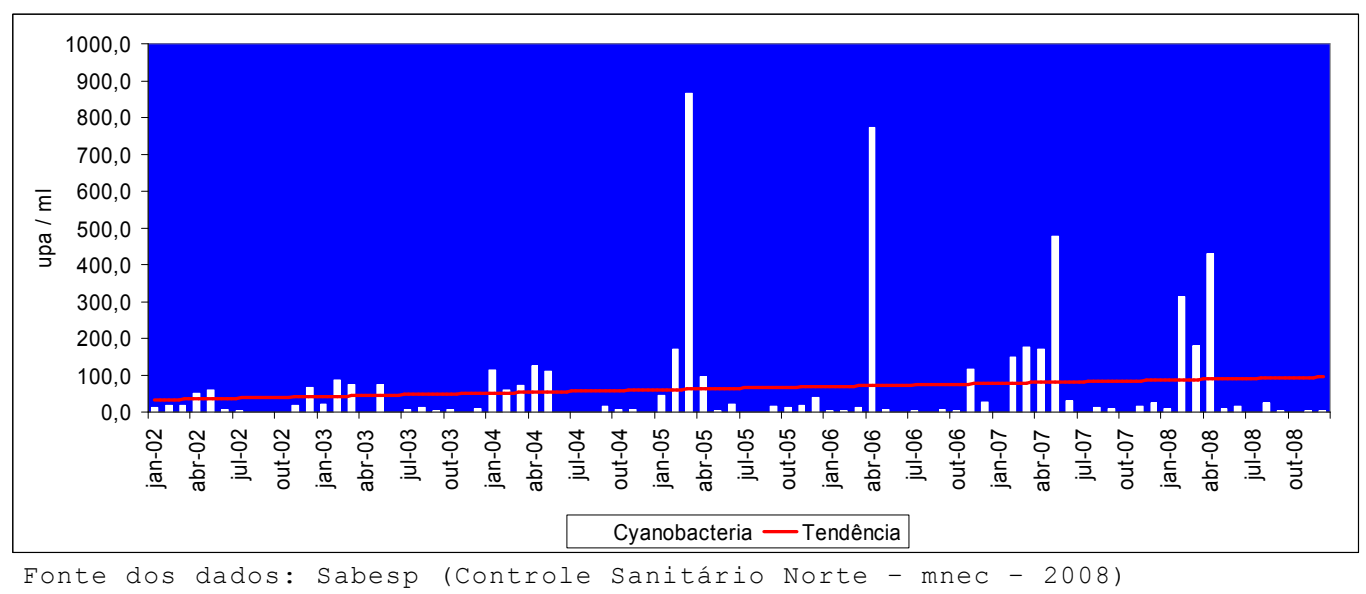

Figura 10 - Cianobactérias na água de captação da ETA de Mairiporã.

- Algas Verdes

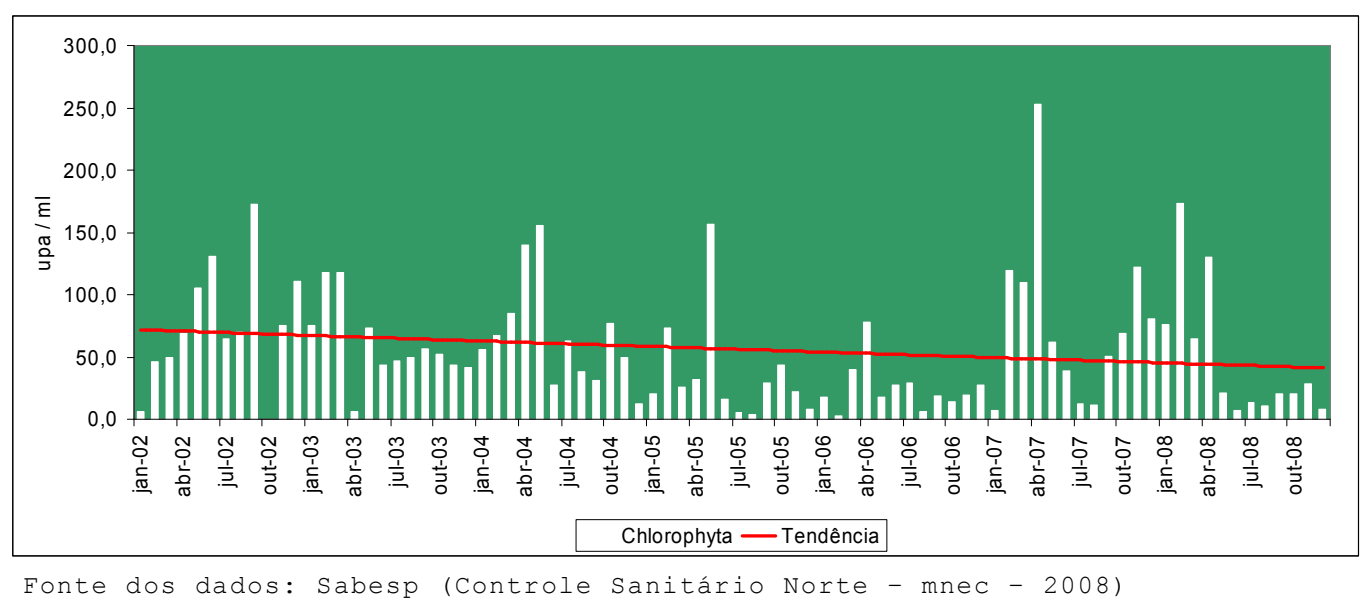

Figura 11 - Algas Verdes na água de captação da ETA de Mairiporã. 
6.1.2 Níveis de Densidades de Cianobactérias das Estações de Tratamento de Água entre 2002 e 2008

Os níveis de densidades de cianobactérias estiveram em elevação nas águas de captação das estações de tratamento de Nazaré Paulista, Mairiporã e Piracaia durante o período estudado (figura 12). Já Bragança Paulista manteve-se com o nível de crescimento de cianobactérias em torno de 100 células por mL neste mesmo período.

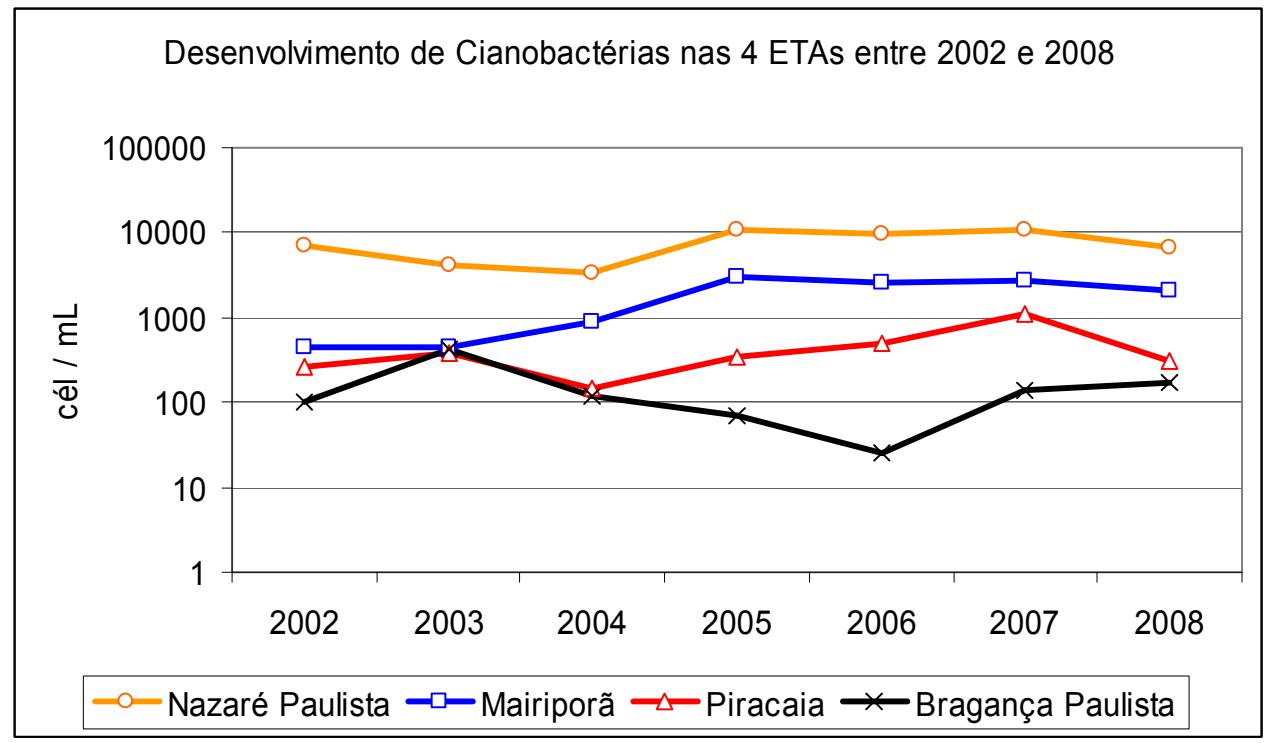

Fonte dos dados: Sabesp (Controle Sanitário Norte - mnec - 2008)

Figura 12 - Demonstração gráfica do desenvolvimento de cianobactérias nas águas de captação das 4 estações de tratamento de água. 
Alguns exemplos de cianobactérias que ocorrem nas águas de captação nestas estações de tratamento:

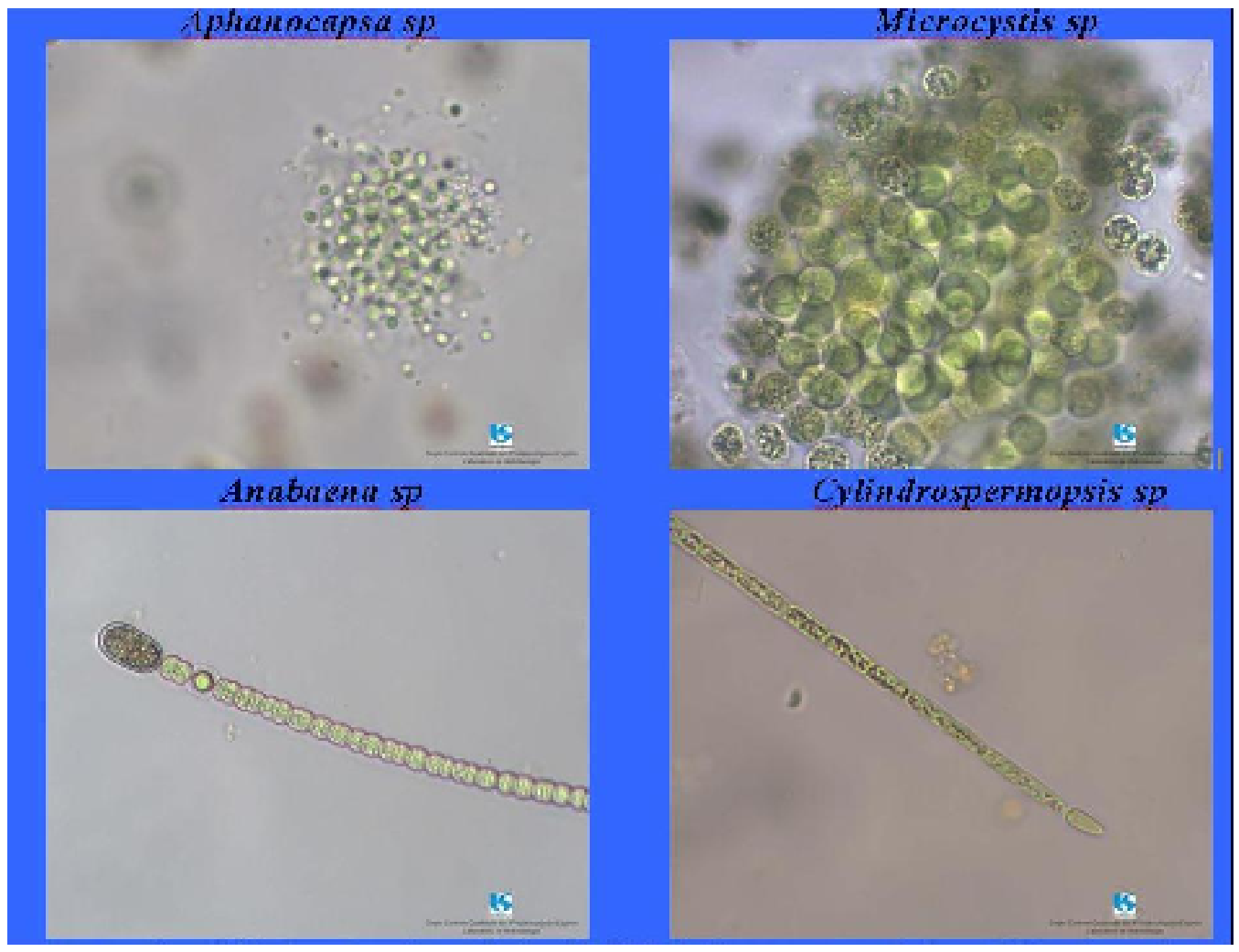

Fonte: Fotos disponibilizadas pelo Laboratório de Hidrobiologia do Depto Controle de Qualidade dos Produtos Águas e Esgotos (TOQ-SABESP).

Figura 13 - Fotos de cianobactérias. 
Para efeito de ilustração e comparação com as cianobactérias, alguns exemplares de algas verdes:

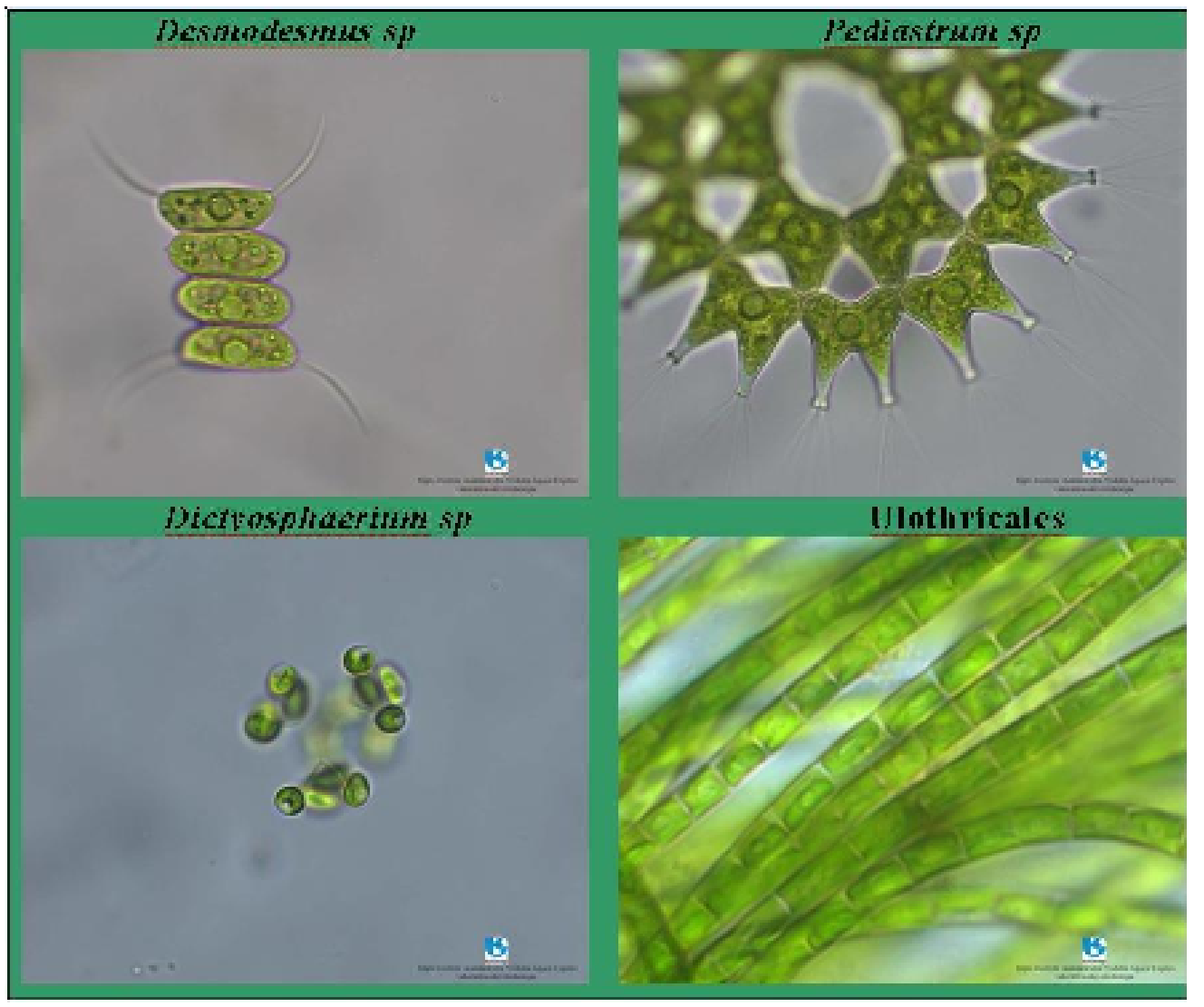

Fonte: Fotos disponibilizadas pelo Laboratório de Hidrobiologia do Depto Controle de Qualidade dos Produtos Águas e Esgotos (TOQ-SABESP).

Figura 14 - Fotos de algas verdes. 
6.1.3 Cianobactérias X Algas Verdes

Neste caso, de acordo com os dados coletados, como mostra o gráfico a seguir (figura 15), destacouse uma quantidade maior de cianobactérias e algas verdes (Chlorophyta) na água de captação da ETA de Nazaré Paulista; as outras ETAs, em relação a estes dois grupos de microrganismos mantiveram-se bem abaixo.

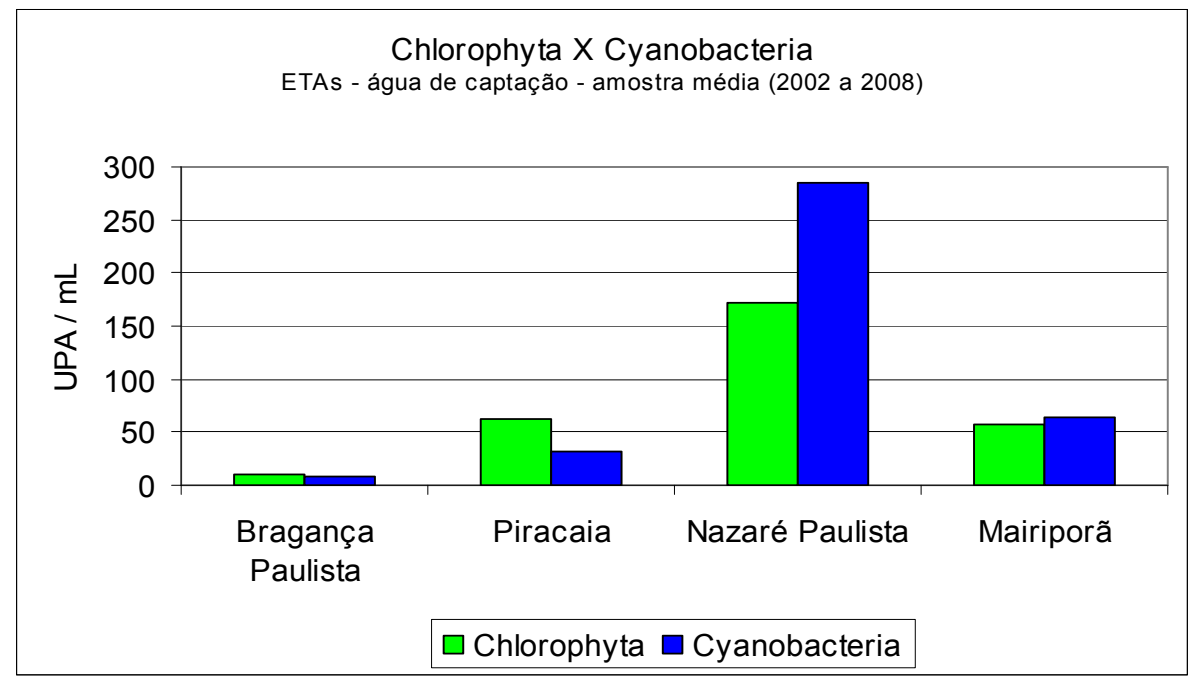

Fonte dos dados: Sabesp (Controle Sanitário Norte - mnec - 2008)

Figura 15 - Comparação entre cianobactérias e algas verdes nas águas de captação em cada estação no período entre os anos de 2002 a 2008 (média). 


\begin{abstract}
Baseado em 2002 como ano inicial do estudo, e como término, em 2008, a relação dos dados entre cianobactérias e algas verdes é demonstrada percentualmente na figura 16, e os resultados das duas variáveis são bem distintos em todas as águas de captação das 4 ETAs, pois enquanto uma variável aumenta a outra diminui.
\end{abstract}

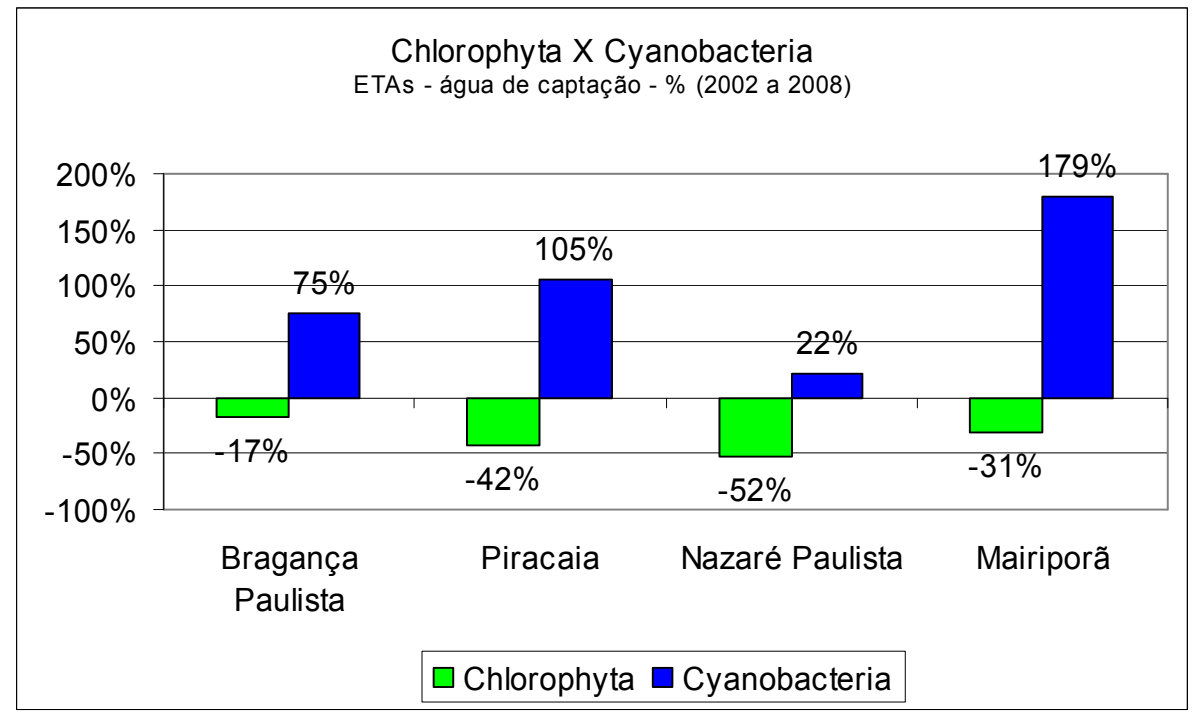

Fonte dos dados: Sabesp (Controle Sanitário Norte - mnec - 2008)

Figura 16 - Taxa (\%) de crescimento de cianobactérias e decaimento de algas verdes no período entre os anos de 2002 a 2008 nas quatro ETAs

Observações:

- base de cálculo: valores de 2002 em relação à média dos valores entre 2002-2008.

- neste caso de comparação, para evitar distorções entre os diversos organismos devido à diferença de tamanho entre os mesmos, a unidade em upa/ml é a unidade utilizada, e que demonstra uma visão espacial de área ocupada pelos microrganismos no corpo d'água. Upa (unidade padrão de área= $400 \mu \mathrm{m}^{2}$ ). 
Para correlacionar estas duas variáveis, Chlorophytas e Cianobactérias (tabela 3), a correlação de Pearson ( $)$ foi o coeficiente considerado, utilizando a seguinte fórmula:

$$
\begin{array}{r}
\rho=\sum_{i=1}^{n}\left(x_{i}-x^{*}\right)\left(y_{i}-y^{*}\right) / \sqrt{ } \sum_{i=1}^{n}\left(x_{i}-x^{*}\right)^{2} \\
\sum_{i=1}^{n}\left(y_{i}-y^{*}\right)^{2} ; \\
\text { onde } x_{1}, x_{2}, \ldots, x_{n} \text { e } y_{1}, y_{2}, \ldots, y_{n} \text { são os }
\end{array}
$$
valores medidos de ambas as variáveis; e $x^{*} e y^{*}$ são as médias aritméticas de ambas as variáveis.

Este coeficiente, normalmente representado por " $\rho "$ assume apenas valores entre -1 e 1 . Desta forma, afirma-se, segundo o coeficiente de correlação de Pearson, que se o resultado for:

a) 0,70 para mais (em direção a 1) ou para menos (em direção a -1) indica uma forte correlação.

b) 0,30 a 0,70 positivo ou negativo indica correlação moderada.

c) 0 a 0,30 positivo ou negativo indica fraca correlação.

Tabela 3 - Relação e cálculo de valores de amostra

\begin{tabular}{|c|c|c|c|c|c|c|c|}
\hline ETAs & $\begin{array}{c}\text { X } \\
\text { Chlorophyta }\end{array}$ & $x_{i}-x^{*}$ & $\left.x_{i}-x^{*}\right)^{2}$ & $\begin{array}{c}\text { y } \\
\text { Ciano- } \\
\text { bactérias }\end{array}$ & $y_{i}-y^{*}$ & $\left(y_{i}-y^{*}\right)^{2}$ & $\begin{array}{l}\left(x_{i}-x^{*}\right) \\
\left(y_{i}-y^{*}\right)\end{array}$ \\
\hline $\begin{array}{l}\text { Bragança } \\
\text { Paulista }\end{array}$ & 10,29 & 65,21 & 4252,57 & 8,70 & 88,64 & 7857,33 & 5780,47 \\
\hline Piracaia & 62,88 & & 159,45 & 32,00 & 65,34 & 4269,21 & 825,05 \\
\hline $\begin{array}{c}\text { Nazaré } \\
\text { Paulista }\end{array}$ & 172,32 & 6,82 & 9374,35 & 284,96 & 87,61 & 35199,32 & 18165,10 \\
\hline \multirow[t]{3}{*}{ Mairiporã } & 56,52 & & 360,33 & 63,71 & 33,63 & 1131,25 & 638,45 \\
\hline & 75,50 & & 14146,69 & 97,34 & & 48457,11 & 25409,06 \\
\hline & $X^{\star}$ & & $\Sigma$ & $\mathrm{y}^{*}$ & & $\Sigma$ & $\Sigma$ \\
\hline
\end{tabular}
média de Algas Verdes (Chlorophyta) e Cianobactérias em UPA/mL (2002-2008).

Resultado:

$\rho=25409,06 / V 14146,69$ X 48457,11

$\rho=0,97$ (Coeficiente de correlação de Pearson)

Observação:

- Foi utilizada a média das amostras de água de captação das 4 ETAs no período de 2002-2008 em UPA/mL.

- UPA: Unidade Padrão de Área (400 $\left.\mathrm{m}^{2}\right)$ 


\subsection{VARIÁVEIS AMBIENTAIS}

6.2.1 Temperatura

ETA-Bragança Paulista (Ponto de coleta: 33B1)

Registros de temperatura da água captada pela ETA de Bragança Paulista (figura 17) mostraram resultados em elevação desde 2002 a 2008, oscilando numa faixa de 20 a $22{ }^{\circ} \mathrm{C}$.

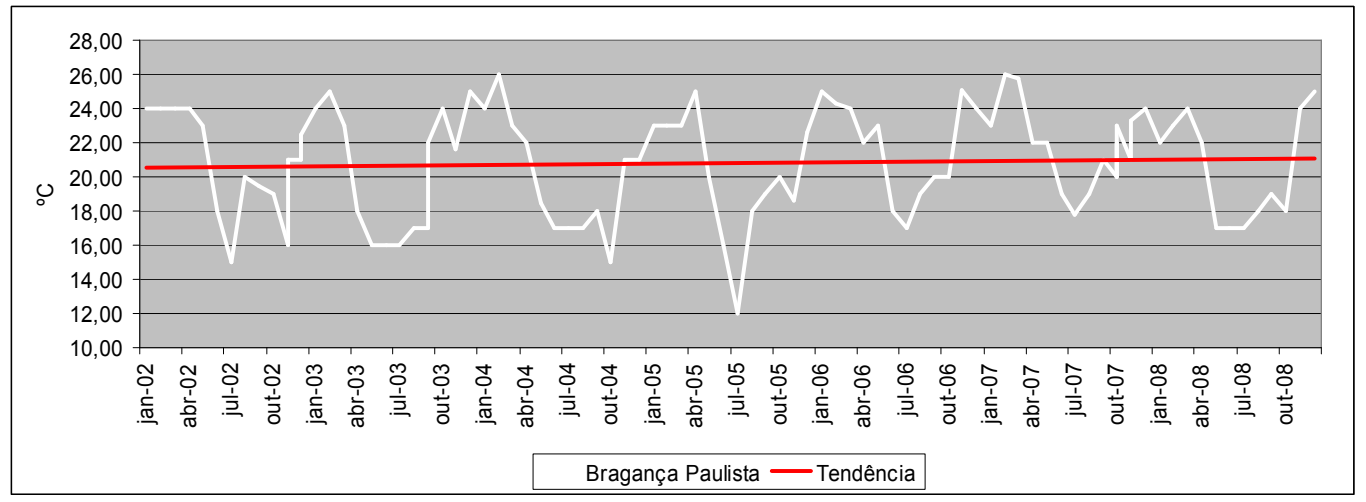

Fonte dos dados: Sabesp (Controle Sanitário Norte - mnec - 2008)

Figura 17 - Variação da Temperatura na água de captação da ETA de Bragança Paulista. 
ETA-Piracaia (Ponto de coleta: 42B1)

\begin{abstract}
Registros de temperatura da água captada pela ETA de Piracaia (figura 18) também mostraram resultados entre 20 e $22^{\circ} \mathrm{C}$ para o período estudado, porém não houve elevação, mantendo-se numa linha média mais constante.
\end{abstract}

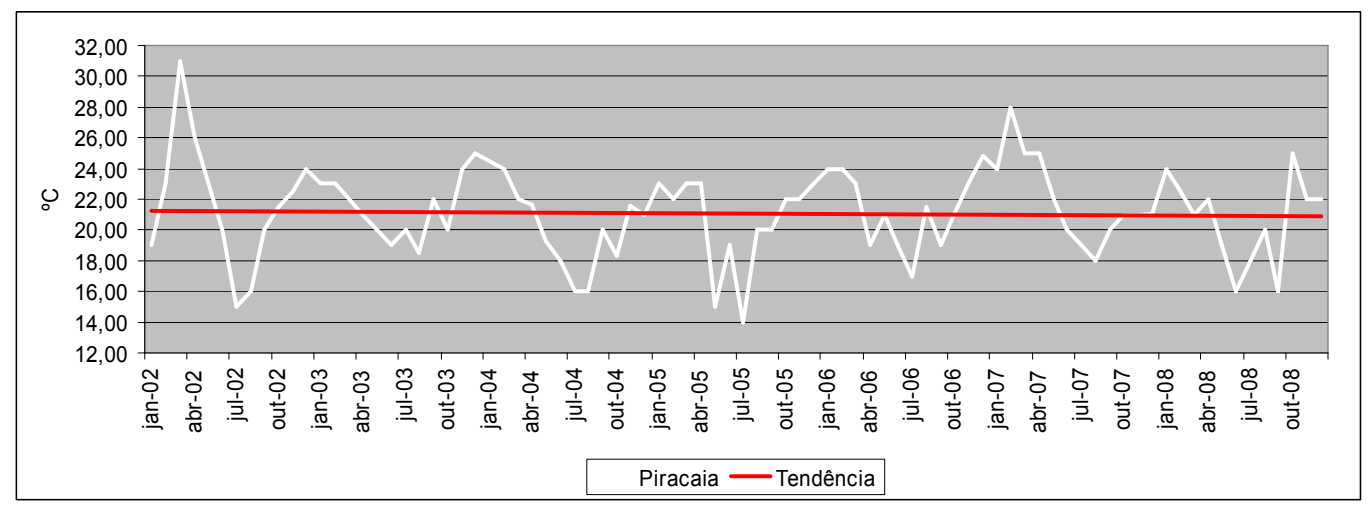

Fonte dos dados: Sabesp (Controle Sanitário Norte - mnec - 2008)

Figura 18 - Variação da Temperatura na água de captação da ETA de Piracaia. 
ETA-Nazaré Paulista (Ponto de coleta: 41B1)

Neste caso da ETA de Nazaré Paulista (figura 19), a temperatura oscilou acima das demais águas captadas, entre 22 e $24{ }^{\circ} \mathrm{C}$, elevando-se o aquecimento de sua água de captação desde 2002 a 2008 .

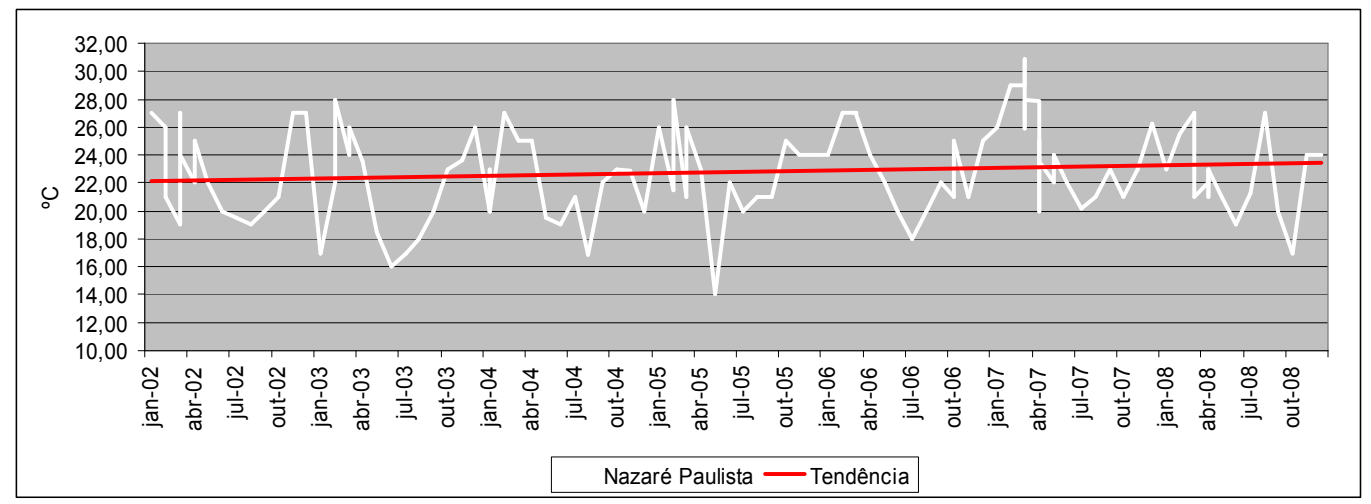

Fonte dos dados: Sabesp (Controle Sanitário Norte - mnec - 2008)

Figura 19 - Variação da Temperatura na água de captação da ETA de Nazaré Paulista. 
ETA-Mairiporã (Ponto de coleta: 19B1)

\begin{abstract}
Para a ETA de Mairiporã (figura 20), a temperatura da água de captação manteve-se em torno de $22{ }^{\circ} \mathrm{C}$ no período de estudo.
\end{abstract}

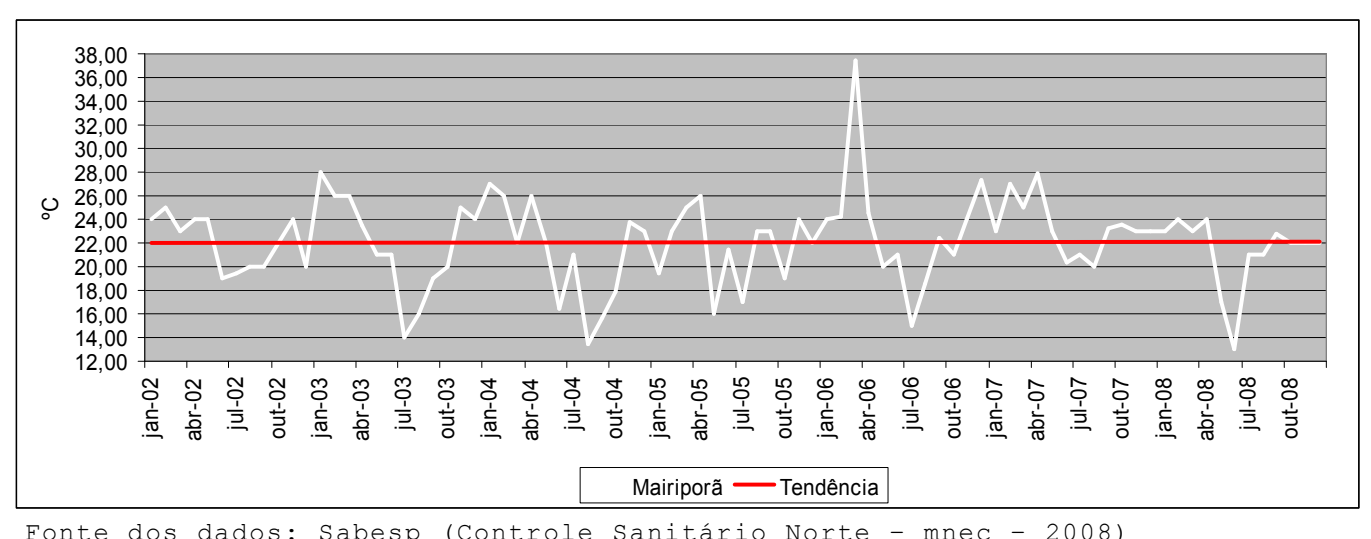

Figura 20 - Variação da Temperatura na água de captação da ETA de Mairiporã. 
Para temperatura de águas captadas pelas quatro estações de tratamento, durante o período de estudo, destacaram-se valores como mostra o quadro a seguir:

Quadro 2 - Meses que apresentaram as mais altas e as mais baixas temperaturas entre o período de 2002 e 2008 nas seguintes ETAs: Bragança Paulista (33B1), Piracaia (42B1), Nazaré Pauilista (41B1) e Mairiporã (33B1).

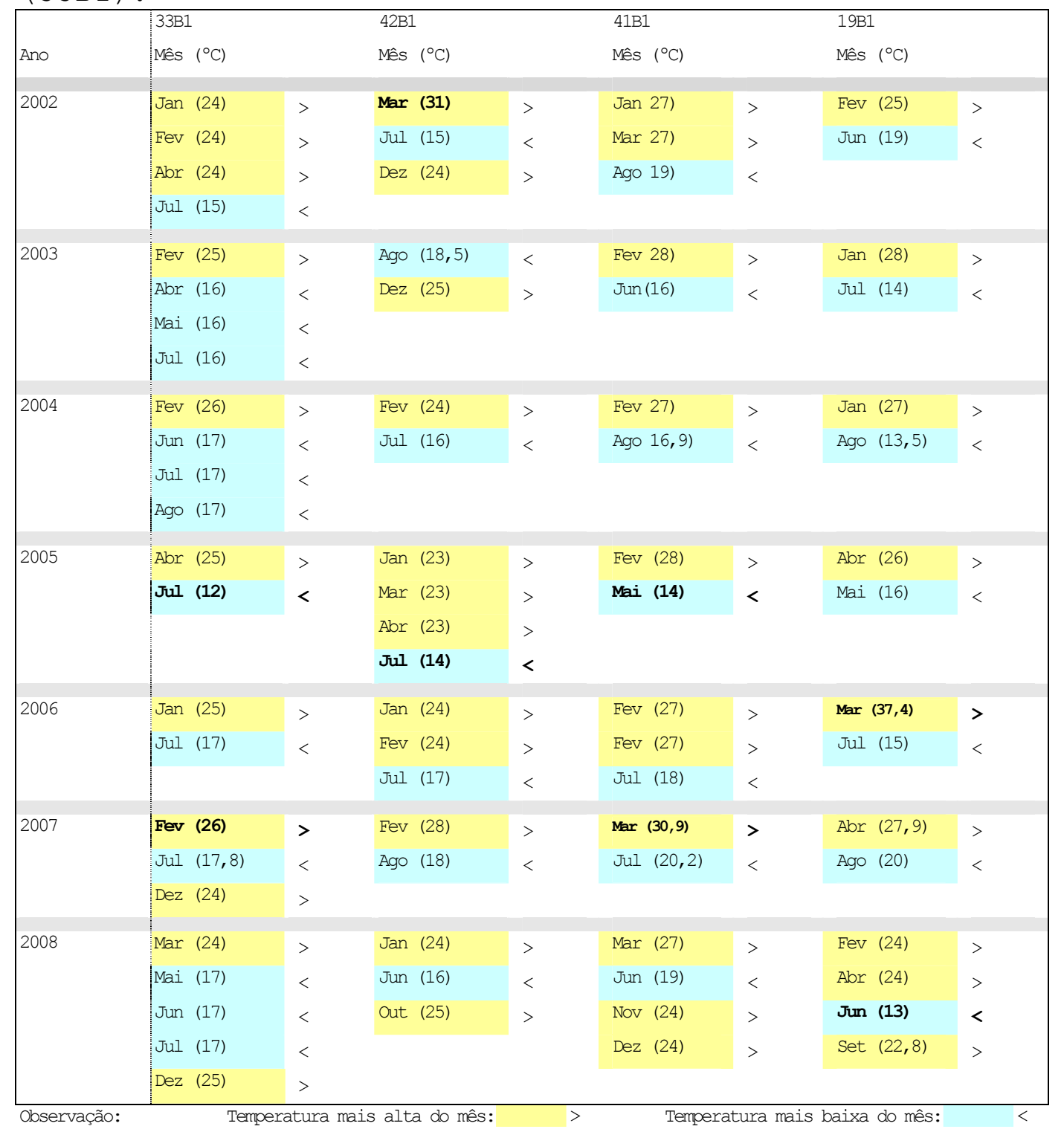




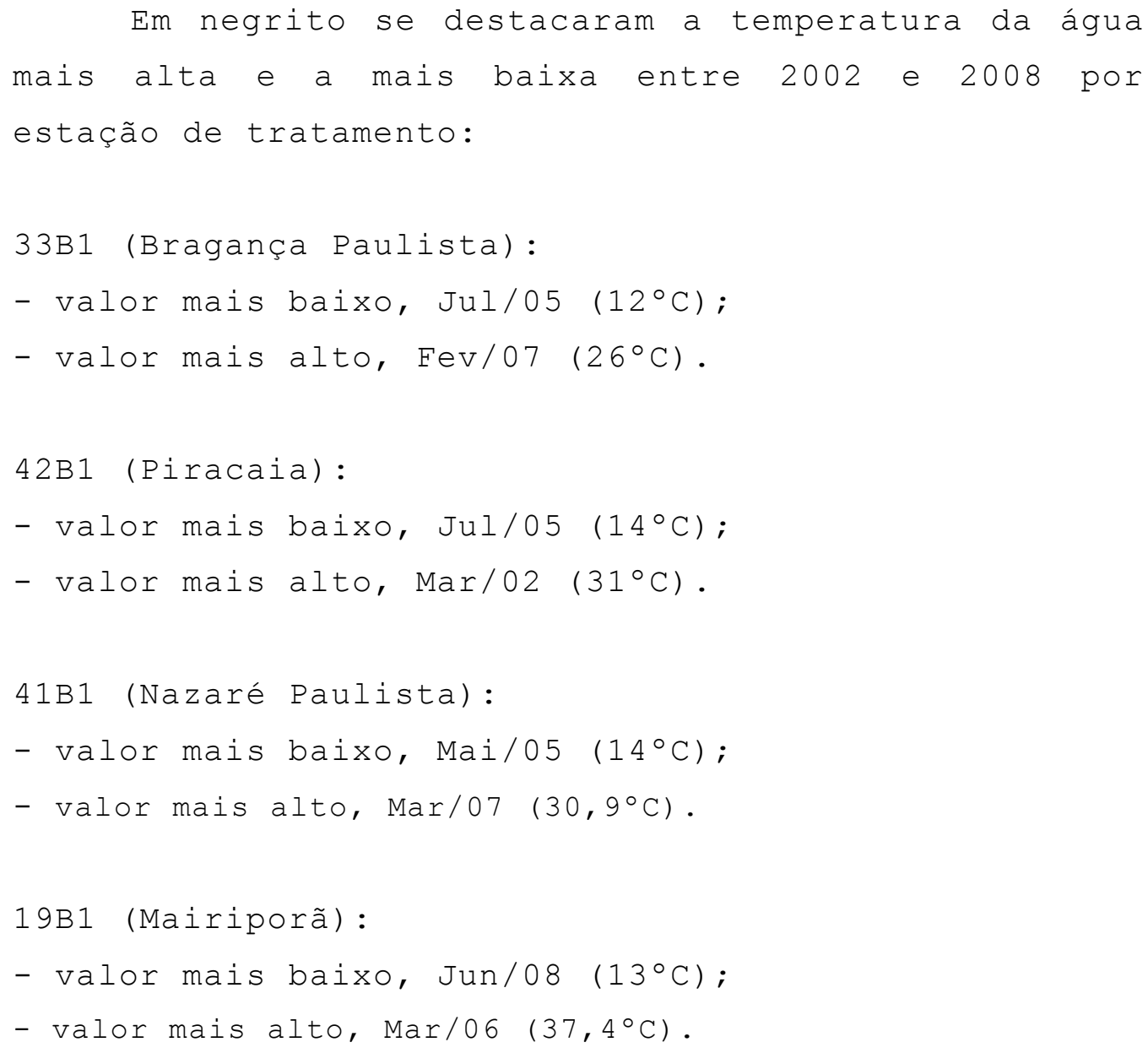

6.2.2 Concentração de Fósforo Total e Categorias de Estado Trófico das Águas de Captação das 4 Estações em Estudo

Observação:

- Para Categorias de Estado Trófico a variável disponível utilizada foi a do Fósforo Total. 
Águas pertencentes a rios: ETA-Bragança Paulista (Ponto de coleta: 33B1) e ETA-Piracaia (Ponto de coleta: 42B1)

Sendo de rios as água de captação da ETA de Bragança Paulista e da ETA de Piracaia, consideraramse na figura 21 as várias categorias de estado trófico para avaliar as condições em que se encontravam os mananciais destas estações de tratamento entre 2004 e 2008. Segundo CONAMA 357/05, a concentração de Fósforo total máxima permitida é de $0,100 \mathrm{mg} / \mathrm{L}$ (lótico-rio).

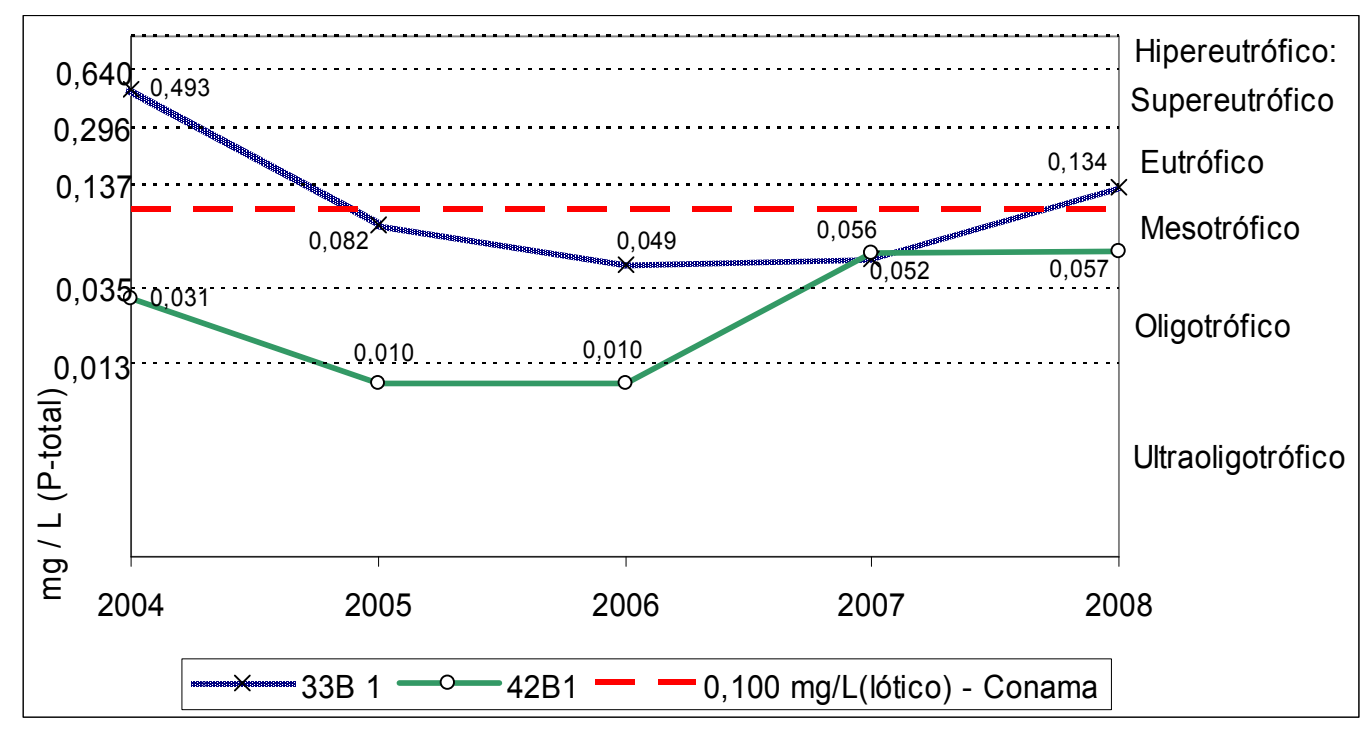

Fonte dos dados: Sabesp (Controle Sanitário Norte - mnec - 2008)

Figura 21 - Variação da concentração de Fósforo total nas águas de captação das ETAs de Bragança Paulista (33B1) e Piracaia (42B1).

Observações:

- Estes valores foram calculados por média aritmética, sendo os ensaios semestrais e disponíveis desde 2004.

- Parâmetro para Fósforo Total (CONAMA-357/05 - água doce classe II): $\leq 0,100 \mathrm{mg} / \mathrm{l}$, para ambientes lóticos. 
Águas pertencentes à represa e ambiente intermediário: ETA-Nazaré Paulista (Ponto de coleta: 41B1) e ETA-Mairiporã (Ponto de coleta: 19B1)

A seguir, a figura 22 mostra, desde 2004 a 2008, as categorias de estado trófico das águas de captação da ETA de Nazaré Paulista considerando suas águas de ambiente lêntico (represa), com concentração de Fósforo total máxima de 0,030 mg/L (CONAMA 357/05); e as águas de captação da ETA de Mairiporã como ambiente intermediário, ou seja, com concentração de Fósforo total até 0,050 mg/L (CONAMA $357 / 05)$.

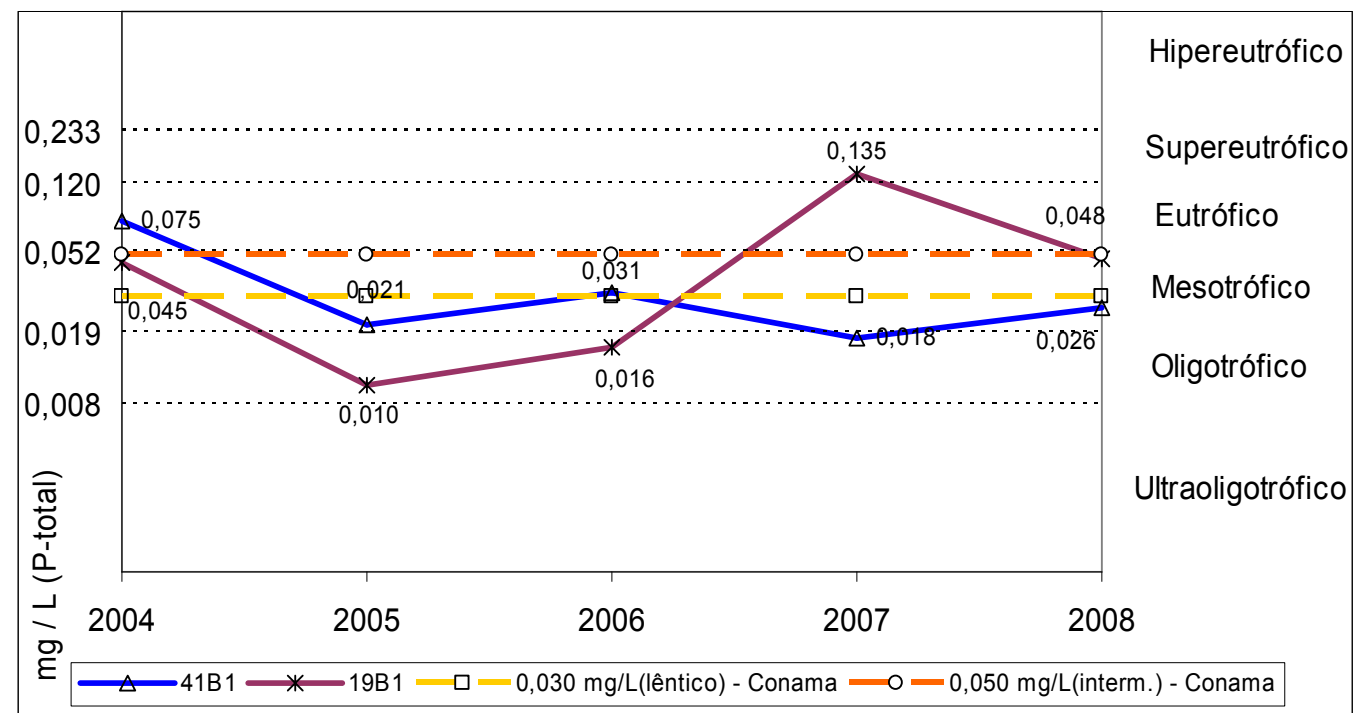

Fonte dos dados: Sabesp (Controle Sanitário Norte - mnec - 2008)

Figura 22 - Variação da concentração de Fósforo total nas águas de captação das ETAs de Nazaré Paulista (41B1) e Mairiporã (19B1).

Observações:

- Estes valores foram calculados em média aritmética, sendo os ensaios semestrais e disponíveis desde 2004.

- Parâmetro para Fósforo Total (CONAMA-357/05 - água doce classe II):

$\leq 0,030 \mathrm{mg} / \mathrm{l}$, para ambientes lênticos;

$\leq 0,050 \mathrm{mg} / 1$, para ambientes intermediários; 
6.2.3 Nitrogênio na forma de Nitrato

Os resultados das variações das concentrações de nitrato das águas de captação dos seguintes pontos de coleta: 33B1 (ETA-Bragança Paulista), $42 B 1$ (ETAPiracaia), 41B1 (ETA-Nazaré Paulista) e $19 \mathrm{~B} 1$ (ETAMairiporã), foram dispostos em gráfico na figura 23, considerando $10 \mathrm{mg} / \mathrm{L}$ uma concentração máxima permitida (CONAMA $357 / 05$ ).

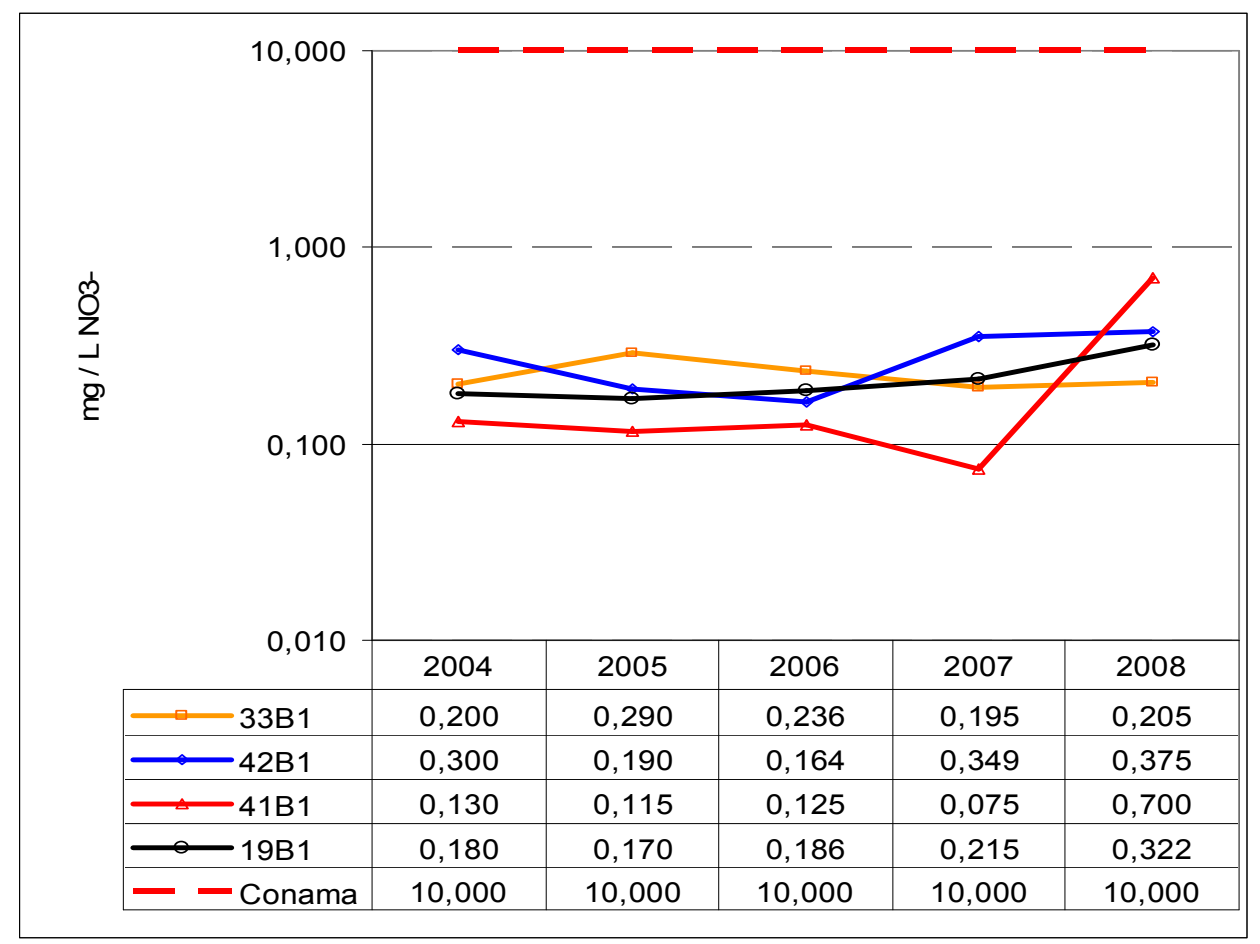

Fonte dos dados: Sabesp (Controle Sanitário Norte - mnec - 2008)

Figura 23 - Variação da concentração de Nitrato na água de captação das ETAs de Bragança Paulista (33B1), Piracaia (42B1), Nazaré Paulista (41B1) e Mairiporã (19B1).

Observações:

- Estes valores foram calculados por média aritmética, sendo os ensaios semestrais e disponíveis desde 2004.

- Parâmetro para Nitrato (CONAMA-357/05 - água doce - classe II) : $\leq 10 \mathrm{mg} / \mathrm{I}$ 
6.2.4 Nitrogênio na forma de Nitrogênio Amoniacal

\section{Ponto de coleta: 33B1}

Para a água de captação da ETA de Bragança Paulista (33B1), a seguir (figura 24), os resultados das variações das concentrações de nitrogênio amoniacal foram representado graficamente, considerando as concentrações máximas permitidas de acordo com o pH da água (CONAMA 357/05).

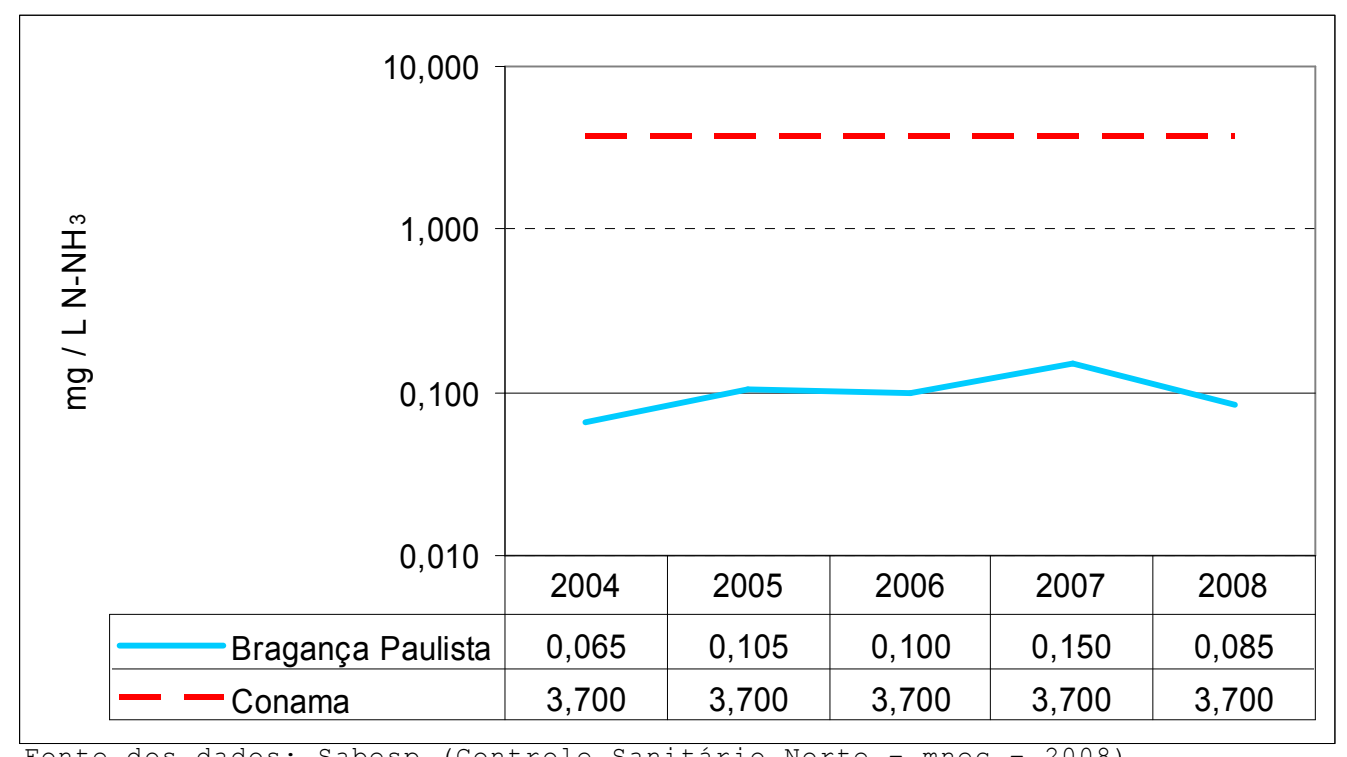

Figura 24 - Variação da concentração de Nitrogênio Amoniacal na água de captação da ETA de Bragança Paulista.

Observações:

- Estes valores foram calculados por média aritmética, sendo os ensaios semestrais e disponíveis desde 2004 .

- Parâmetro para Nitrogênio Amoniacal (CONAMA-357/05 - água doce - classe II):

$3,7 \mathrm{mg} / \mathrm{l} \mathrm{N}$, para $\mathrm{pH} \leq 7,5$

$2,0 \mathrm{mg} / \mathrm{l} \mathrm{N}$, para $7,5<\mathrm{pH} \leq 8,0$

$1,0 \mathrm{mg} / \mathrm{l} \mathrm{N}$, para $8,0<\mathrm{pH} \leq 8,5$

$0,5 \mathrm{mg} / \mathrm{l} \mathrm{N}$, para $\mathrm{pH}>8,5$ 


\section{Ponto de coleta: 42B1}

Para a água da ETA de Piracaia (42B1), os resultados das variações das concentrações de nitrogênio amoniacal, no período estudado, foram representado graficamente (figura 25), considerando as concentrações máximas permitidas de acordo com 0 pH da água (CONAMA 357/05).

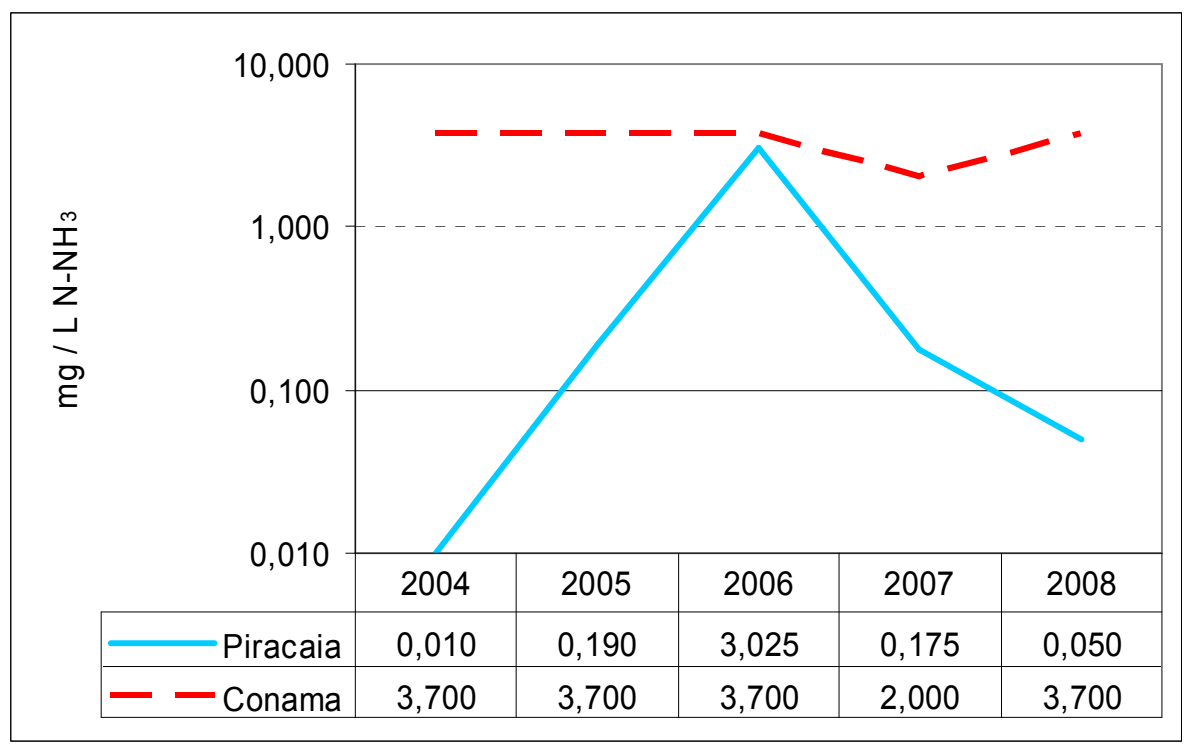

Fonte dos dados: Sabesp (Controle Sanitário Norte - mnec - 2008)

Figura 25 - Variação da concentração de Nitrogênio Amoniacal na água de captação da ETA de Piracaia.

Observações:

- Estes valores foram calculados por média aritmética, sendo os ensaios semestrais e disponíveis desde 2004.

- Parâmetro para Nitrogênio Amoniacal (CONAMA-357/05 - água doce - classe II):

$3,7 \mathrm{mg} / \mathrm{l} \mathrm{N}$, para $\mathrm{pH} \leq 7,5$

$2,0 \mathrm{mg} / 1 \mathrm{~N}$, para $7,5<\mathrm{pH} \leq 8,0$

$1,0 \mathrm{mg} / \mathrm{l} \mathrm{N}$, para $8,0<\mathrm{pH} \leq 8,5$

$0,5 \mathrm{mg} / \mathrm{l} \mathrm{N}$, para $\mathrm{pH}>8,5$ 


\section{Ponto de coleta: 41B1}

O próximo gráfico (figura 26) representa as variações das concentrações de nitrogênio amoniacal da água de captação da ETA de Nazaré Paulista (41B1) ao longo do período de 2004 a 2008. Considerou-se as concentrações máximas permitidas de acordo com o pH da água (CONAMA 357/05).

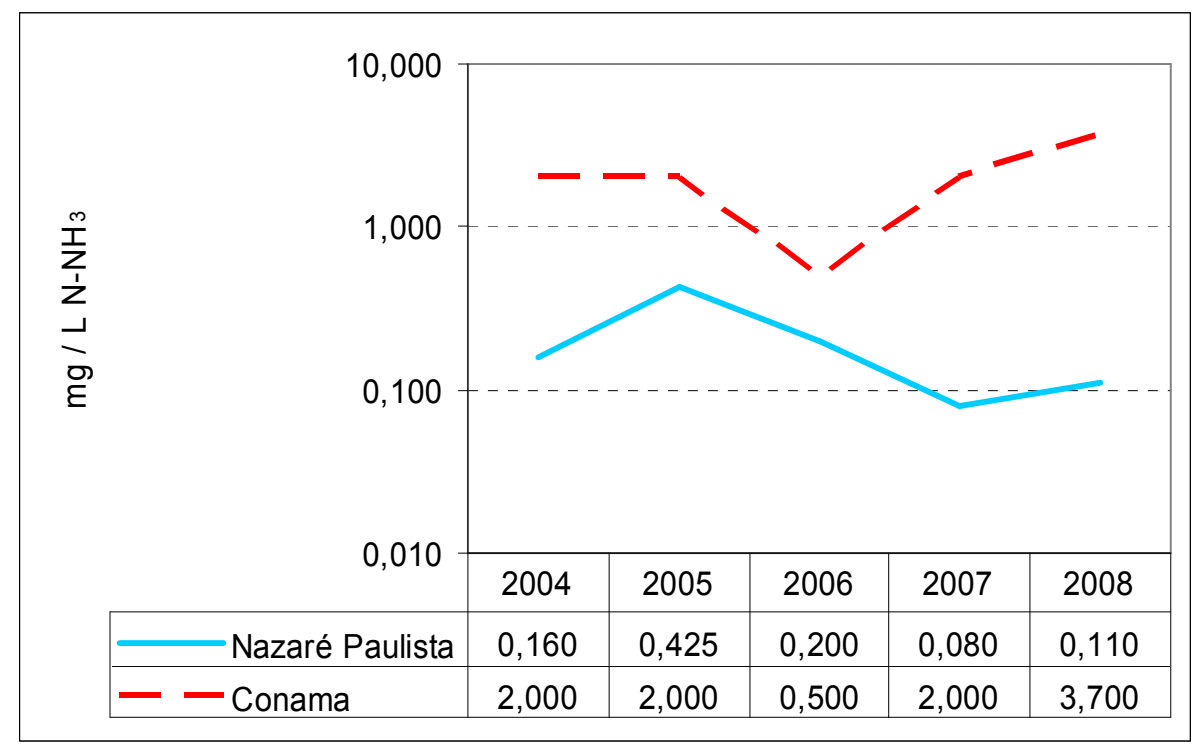

Fonte dos dados: Sabesp (Controle Sanitário Norte - mnec - 2008)

Figura 26 - Variação da concentração de Nitrogênio Amoniacal na água de captação da ETA de Nazaré Paulista.

Observações:

- Estes valores foram calculados por média aritmética, sendo os ensaios semestrais e disponíveis desde 2004.

- Parâmetro para Nitrogênio Amoniacal (CONAMA-357/05 - água doce - classe II):

$3,7 \mathrm{mg} / \mathrm{l} \mathrm{N}$, para $\mathrm{pH} \leq 7,5$

$2,0 \mathrm{mg} / \mathrm{l} \mathrm{N}$, para $7,5<\mathrm{pH} \leq 8,0$

$1,0 \mathrm{mg} / \mathrm{l} \mathrm{N}$, para $8,0<\mathrm{pH} \leq 8,5$

$0,5 \mathrm{mg} / \mathrm{l} \mathrm{N}$, para $\mathrm{pH}>8,5$ 


\section{Ponto de coleta: 19B1}

$\mathrm{Na}$ figura 27, foram representadas as variações das concentrações de nitrogênio amoniacal da água de captação da ETA de Mairiporã (19B1) ao longo do período de 2004 a 2008, e assim como nas demais ETAs, considerou-se as concentrações máximas permitidas de acordo com o pH da água (CONAMA 357/05).

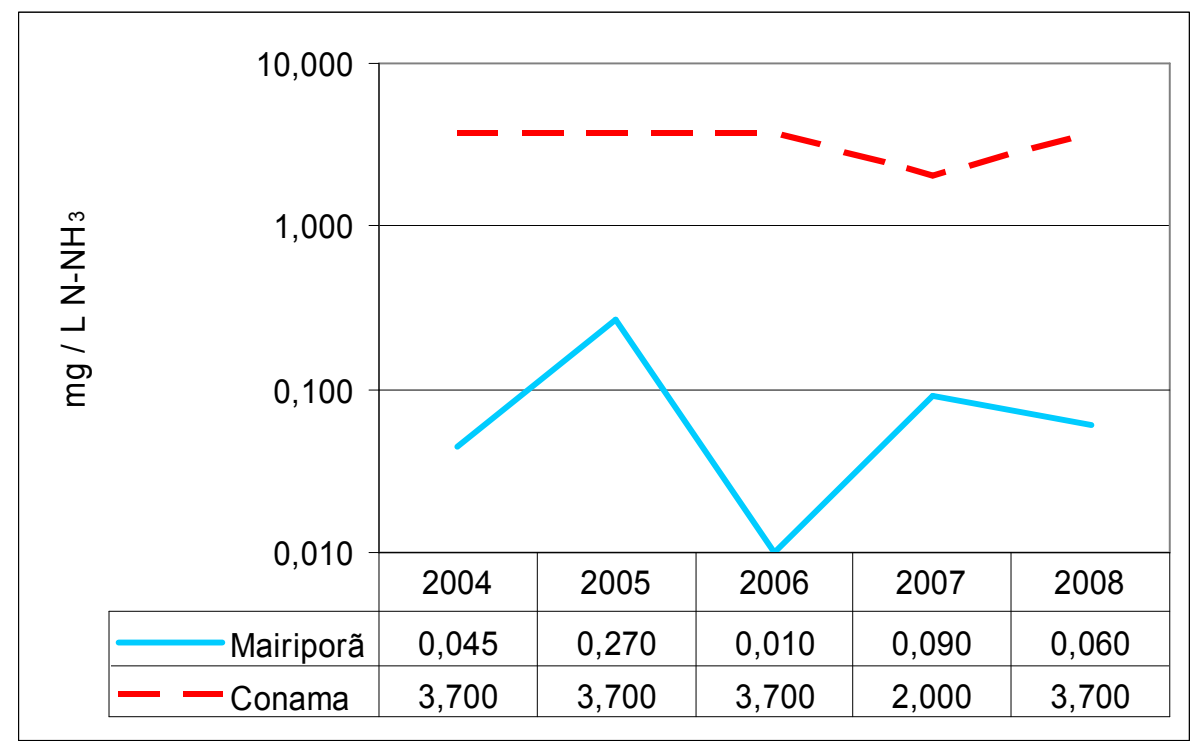

Fonte dos dados: Sabesp (Controle Sanitário Norte - mnec - 2008)

Figura 27 - Variação da concentração de Nitrogênio Amoniacal na água de captação da ETA de Mairiporã.

Observações:

- Estes valores foram calculados por média aritmética, sendo os ensaios semestrais e disponíveis desde 2004 .

- Parâmetro para Nitrogênio Amoniacal (CONAMA-357/05 - água doce - classe II):

$3,7 \mathrm{mg} / \mathrm{l} \mathrm{N}$, para $\mathrm{pH} \leq 7,5$

$2,0 \mathrm{mg} / \mathrm{l} \mathrm{N}$, para $7,5<\mathrm{pH} \leq 8,0$

$1,0 \mathrm{mg} / \mathrm{l} \mathrm{N}$, para $8,0<\mathrm{pH} \leq 8,5$

$0,5 \mathrm{mg} / \mathrm{l} \mathrm{N}$, para $\mathrm{pH}>8,5$ 
6.2.5 Oxigênio Dissolvido

De acordo com os resultados coletados do período estudado, as variações das concentrações de oxigênio dissolvido das águas de captação dos seguintes pontos de coleta: 33B1 (ETA-Bragança Paulista), 42B1 (ETA-Piracaia), 41B1 (ETA-Nazaré Paulista) e 19B1 (ETA-Mairiporã), foram representadas num só gráfico (figura 28), considerando 5 mg/L uma concentração mínima permitida para águas doce classeII (CONAMA 357/05).

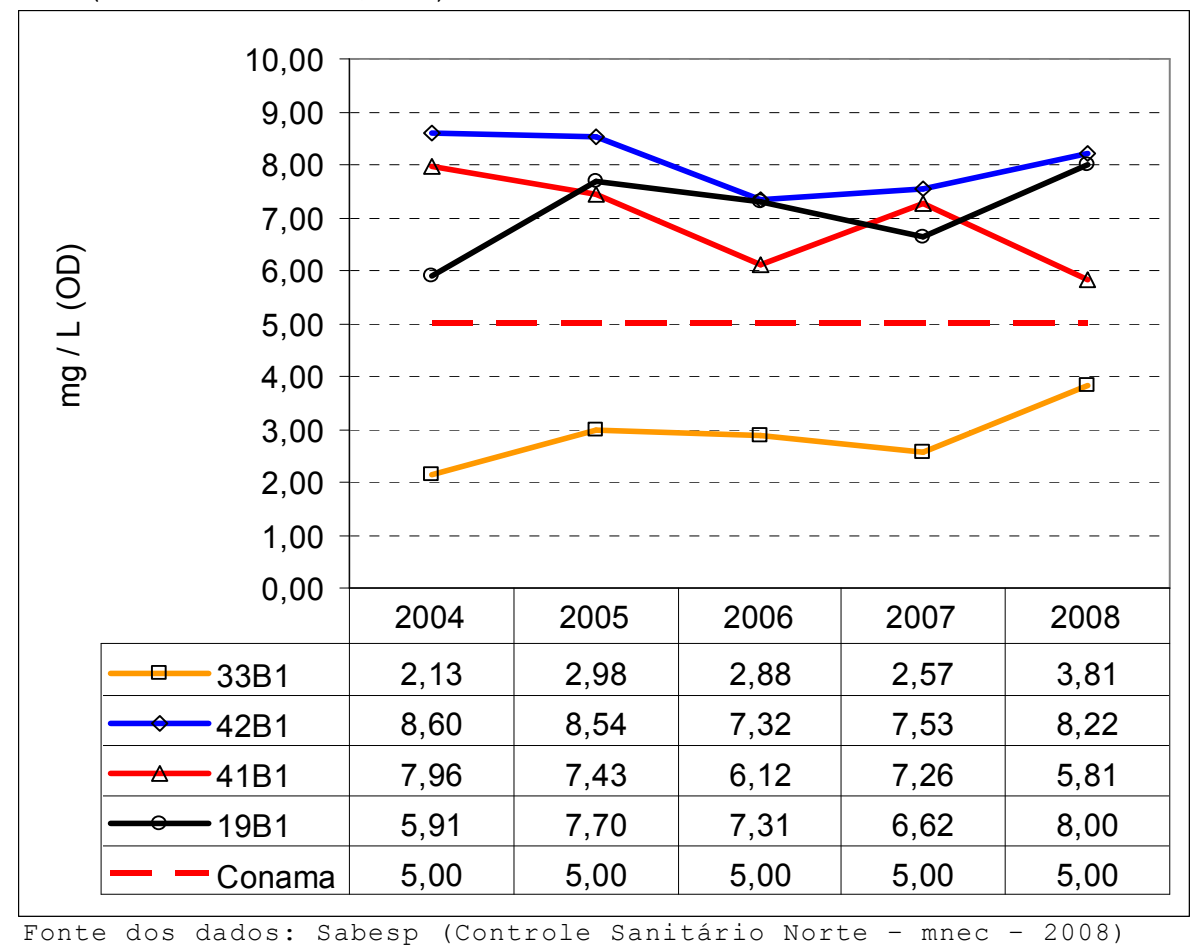

Figura 28 - Variação da concentração de Oxigênio Dissolvido na água de captação das ETAs de Bragança Paulista (33B1), Piracaia (42B1), Nazaré Paulista (41B1) e Mairiporã (19B1).

Observações:

- Estes valores foram calculados por média aritmética, sendo os ensaios semestrais e disponíveis desde 2004.

- Parâmetro para Oxigênio Dissolvido (CONAMA-357/05 - água doce - classe II) : $\geq 5 \mathrm{mg} / 1 \mathrm{O}_{2}$ 
6.2.6 Cor, pH e Turbidez

\begin{abstract}
Para efeito de estudos e comparação com os parâmetros do CONAMA 357/05, a tabela 4 mostra o valor da média dos resultados de cor e turbidez, e os valores de pH mínimo e pH máximo de cada ano. Estes valores referem-se às águas dos pontos de coleta: 33B1, 42B1, 41B1 e 19B1 durante o período de 2002 a 2008 .
\end{abstract}

Tabela 4 - Cor, pH e Turbidez da água de captação das quatro estações de tratamento de água (período: 2002$2008)$

\begin{tabular}{|c|c|c|c|c|c|c|c|c|c|}
\hline ETAs & Variáveis & 2002 & 2003 & 2004 & 2005 & 200 & 2007 & 2008 & Conama 357/05 \\
\hline \multirow{4}{*}{$\begin{array}{c}\text { Bragança } \\
\text { Paulista } \\
\text { (33B1) }\end{array}$} & $\operatorname{Cor}(\mathrm{uH})$ & 172 & 75 & 108 & 91 & 88 & 94 & 105 & $\leq 75 \mathrm{mg} \mathrm{Pt}-\mathrm{Co} / \mathrm{L}$ \\
\hline & pH (mín) & 6,5 & 6,4 & 6,4 & 6,5 & 6,6 & 6,0 & 6,2 & 6,0 (mínimo) \\
\hline & pH (máx) & 7,0 & 7,1 & 7,1 & 7,1 & 7,2 & 7,3 & 6,8 & 9,0 (máximo) \\
\hline & Turb. (UT) & 34 & 17 & 22 & 24 & 15 & 21 & 27 & $\leq 100 \mathrm{UT}$ \\
\hline \multirow{4}{*}{$\begin{array}{l}\text { Piracaia } \\
(42 \mathrm{~B} 1)\end{array}$} & $\operatorname{Cor}(\mathrm{uH})$ & 12 & 37 & 39 & 34 & 36 & 44 & 32 & $\leq 75 \mathrm{mg} \mathrm{Pt}-\mathrm{Co} / \mathrm{L}$ \\
\hline & pH (mín) & 6,7 & 6,7 & 6,8 & 6,8 & 7,1 & 6,8 & 6,3 & 6,0 (mínimo) \\
\hline & pH (máx) & 7,4 & 7,6 & 7,3 & 7,3 & 7,5 & 7,6 & 7,2 & 9,0 (máximo) \\
\hline & Turb. (UT) & 8 & 7 & 10 & 9 & 8 & 12 & 10 & $\leq 100 \mathrm{UT}$ \\
\hline \multirow{4}{*}{$\begin{array}{l}\text { Nazaré } \\
\text { Paulista } \\
\text { (41B1) }\end{array}$} & Cor $(\mathrm{uH})$ & 17 & 8 & 8 & 9 & 18 & 10 & 9 & $\leq 75 \mathrm{mg} \mathrm{Pt}-\mathrm{Co} / \mathrm{L}$ \\
\hline & pH (mín) & 6,8 & 7,1 & 6,9 & 4,6 & 6,9 & 7,0 & 6,6 & 6,0 (mínimo) \\
\hline & pH (máx) & 7,7 & 7,8 & 7,6 & 7,6 & 9,2 & 7,6 & 7,4 & 9,0 (máximo) \\
\hline & Turb. (UT) & 3 & 5 & 2 & 4 & 3 & 3 & 4 & $\leq 100 \mathrm{UT}$ \\
\hline \multirow{4}{*}{$\begin{array}{l}\text { Mairiporã } \\
\text { (19B1) }\end{array}$} & Cor $(\mathrm{uH})$ & 13 & 15 & 41 & 31 & 36 & 25 & 24 & $\leq 75 \mathrm{mg} \mathrm{Pt}-\mathrm{Co} / \mathrm{L}$ \\
\hline & $\mathrm{pH}$ (mín) & 6,8 & 5,9 & 5,0 & 4,4 & 6,7 & 6,8 & 6,5 & 6,0 (mínimo) \\
\hline & pH (máx) & 7,3 & 7,4 & 7,2 & 7,4 & 7,4 & 7,6 & 7,1 & 9,0 (máximo) \\
\hline & Turb. (UT) & 17 & 9 & 8 & 13 & 14 & 14 & 13 & $\leq 100$ UT \\
\hline \multicolumn{10}{|c|}{ Fonte dos dados } \\
\hline \multicolumn{10}{|c|}{$\begin{array}{l}\text { Observações: } \\
\text { - Valores em negrito: fora } \\
\text { II (CONAMA-357/05). } \\
\text { - (uH) Unidade Hazen (mg Pt } \\
\text { - (UT) Unidade de turbidez. }\end{array}$} \\
\hline
\end{tabular}


6.2.7 Destaque para Cor e Oxigênio Dissolvido na água bruta da ETA de Bragança Paulista

Analisando os dados encontrados na tabela 4 e na figura 28 com relação à água bruta do ponto de coleta 33Bl (ETA-Bragança Paulista), e tomando-se como base os parâmetros do CONAMA 357/05, foram destacados na tabela 5, a seguir, os resultados da cor em relação ao oxigênio dissolvido.

Tabela 5 - Relação entre cor alta e oxigênio dissolvido baixo na água captada pela ETA de Bragança Paulista.

\begin{tabular}{|c|c|c|c|c|c|c|}
\hline & 2004 & 2005 & 2006 & 2007 & 2008 & Conama 357/05 \\
\hline Cor & 108 & 91 & 88 & 94 & 105 & $\leq 75 \mathrm{mg} \mathrm{Pt-Co} / \mathrm{L}$ \\
\hline OD & 2,13 & 2,98 & 2,88 & 2,57 & 3,81 & $\geq 5 \mathrm{mg} / 1 \mathrm{O}_{2}$ \\
\hline
\end{tabular}




\section{DISCUSSÃO}

Algumas evidências de poluição no manancial
foram observadas nas Estações de Tratamento de Água,
com tendência a diminuir ou aumentar para alguns
grupos planctônicos. Estes microrganismos podem ser
bons indicadores de corpos d'água, como as
cianobactérias, que possibilitam chamar a atenção
sobre as mudanças constantes das condições ambientais
ao longo do tempo que sofrem as águas captadas pelas
estações de tratamento de água. o monitoramento
continuo junto às estações de tratamento das águas de
captação é muito importante, pois a qualquer anomalia
em seus parâmetros, seja biológico, físicos ou
quimicos deve ser redobrada a atenção, considerando
que a captação da água se realiza logo abaixo da
superfície, e em havendo qualquer indicio de
alteração, as suspeitas de alterações na superfície
dos mananciais poderão estar relacionadas a este tipo
de água de camadas inferiores.




\subsection{VARIÁVEIS BIOLÓGICAS}

\subsubsection{Cianobactérias}

Neste estudo, as cianobactérias foram
consideradas como a principal variável em ambiente
aquático, pois como um indicador biológico muito
estudado por vários autores apresenta resultados
muito significativos diante dos efeitos da poluição
ambiental. As cianobactérias, diferentemente dos
grupos das algas, de uma forma geral, elas se
apresentam com mais vantagens adaptativas em
condições adversas, tornando-se um dos grupos mais
bem sucedido do fitoplâncton no ambiente.

Nas águas captadas pelas quatro estações, as cianobactérias mais comumente encontradas foram Chroococcales e filamentosas como Anabaena, Oscillatoria e Cylindrospermpsis. Por estarem sempre muito presentes em lagos eutróficos, as Microcystis, Oscillatoria e Cylindrospermopsis requerem atenção quando surge com mais freqüência num determinado manancial considerado não eutrofizado. Um ambiente em mudança pode ser percebido dependendo de uma freqüência maior ou menor de um ou de outro organismo, as cianobactérias são um desses exemplos de microrganismo que lançam mecanismos de sobrevivência em ambientes que sofrem agressões de origem antrópica, como despejos de esgotos domésticos 
em corpos d'água. As reações das cianobactérias, em relação à poluição ambiental, se devem ao desequilíbrio ecológico, pois elas possuem mecanismos naturais de alimentação e de defesa muito bem desenvolvidos. Como exemplo de mecanismos, Esteves (1988; citado por SZAJUBOK, 2000, p.64), descreve dois gêneros de cianobactérias muito importantes atualmente, como indicadores biológicos, relacionados à degradação de ambientes aquáticos, são as Microcystis e Oscillatoria, que têm como característica em comum a formação de vacúolos gasosos, sendo mais uma vantagem de estratégia adaptativa em relação aos demais grupos fitoplanctônicos, para superar a sua própria alta densidade, superior à da água, pois uma densidade alta assim impediria sua permanência de flutuar sobre as camadas mais superiores da coluna d'água. Estes vacúolos são agregados de vesículas gasosas com superfície externa hidrofilica e interna hidrofóbica (Walsby, 1998 apud Mur ET AL, 1999; citado por SZAJUBOK, 2000, p.64), são 10 vezes menos densas que a água. Este recurso é de vital importância, pois atua com flexibilidade, ou seja, o vacúolo pode sofrer enchimento ou esvaziamento dependendo da necessidade das colônias de cianobactérias, permitindo a migração para o fundo da coluna d'água em busca do reabastecimento de nutrientes mais concentrado, como fósforo que fica depositado nos sedimentos, a absorção de fósforo pelas células das cianobactérias é muito rápida e permanecendo várias horas no fundo é suficiente para abastecer o conteúdo intra-celular de fósforo, possibilitando, ao migrarem 
às camadas superficiais, uma reprodução mais intensa, mesmo em condições de deficiência de fósforo nesta água superficial (Sirenko, 1987; citado por SZAJUBOK, 2000, p.65). O afundamento destas colônias ocorre quando estão na superfície produzindo grandes quantidades de carboidratos que atuam como lastro, para em seguida induzirem ao seu próprio afundamento; e o retorno à superfície, ocorre quando posicionadas em regiões mais escuras da coluna d'água, na zona eufótica, no fundo, usam o carboidrato para a respiração, produzindo novas vesículas de gás, tornando-se menos densas que a água e, portanto mais leve elas podem subir à superfície (Utkilen et al, 1985 apud Mur et al, 1999; citado por SZAJUBOK, 2000, p.65).

Durante o período de 2002 a 2008, a densidade de cianobactérias aumentou nas águas de captação das ETAs de Piracaia (figura 6), Nazaré Paulista (figura 8) e Mairiporã (figura 10). E se manteve em níveis mais constantes e mais baixos na água de captação da ETA de Bragança Paulista (figura 4).

Observando a figura 12 numa visão geral das quatro estações de tratamento de água, a demonstração gráfica do desenvolvimento de cianobactérias nas águas de captação das 4 ETAs mostra o nível de densidade (cél/ml) em que cada estação opera, mostrando um discreto aumento no período de 2002 a 2008 em três delas: Piracaia, Nazaré Paulista e Mairiporã, sendo o nível mais elevado para a ETA de Nazaré Paulista que se aproxima dos limites da 
Portaria 518 do Ministério da Saúde. A água de captação da ETA de Bragança Paulista permanece mais constante num nível mais abaixo.

\begin{abstract}
Este acompanhamento do desenvolvimento da densidade de cianobactérias no ponto de captação da estação de tratamento de água em que as empresas de saneamento operam é muito importante com relação à Portaria 518 (Ministério da Saúde), pois implica em monitorar o manancial de acordo com os seguintes critérios:

- Quando não exceder 10.000 células/mL: Monitoramento mensal;

- Quando exceder 10.000 células/mL: Monitoramento semanal;

- Quando exceder 20.000 células/ mL: Monitoramento semanal e realizar teste de microscistina (o valor máximo permitido na saída do tratamento deve ser de $1 \mu \mathrm{g} / \mathrm{L})$.
\end{abstract}

Neste estudo, não se encontrou registros envolvendo as águas de captação que apresentassem valores de microscistina significativos, ficando abaixo até mesmo do permitido para água tratada, mas é sempre bom ficar atento porque há um crescimento de cianobactérias, seja pouco ou muito, demonstrando sinais de contaminação nos mananciais.

Observou-se que as águas no ponto de captação da ETA de Nazaré Paulista poderão atingir uma densidade média de 10.000 células de Cianobactérias/mL por amostragem com maior freqüência nos próximos anos, isto é um sinal de alerta para que todos os envolvidos, seja na operação ou no monitoramento, fiquem mais atentos, pois podem 
ocorrer florações mais freqüentes anualmente, principalmente nos dias ou meses mais quentes do ano em que há uma intensidade de luminosidade maior. As águas de captação das outras estações de tratamento com densidade de cianobactérias em escalas mais abaixo, raramente ultrapassaram estes limites, apesar da densidade crescente deste indicador em Piracaia e Mairiporã, sendo Bragança Paulista um caso para um estudo mais detalhado, pois não há um crescimento de cianobactéria.

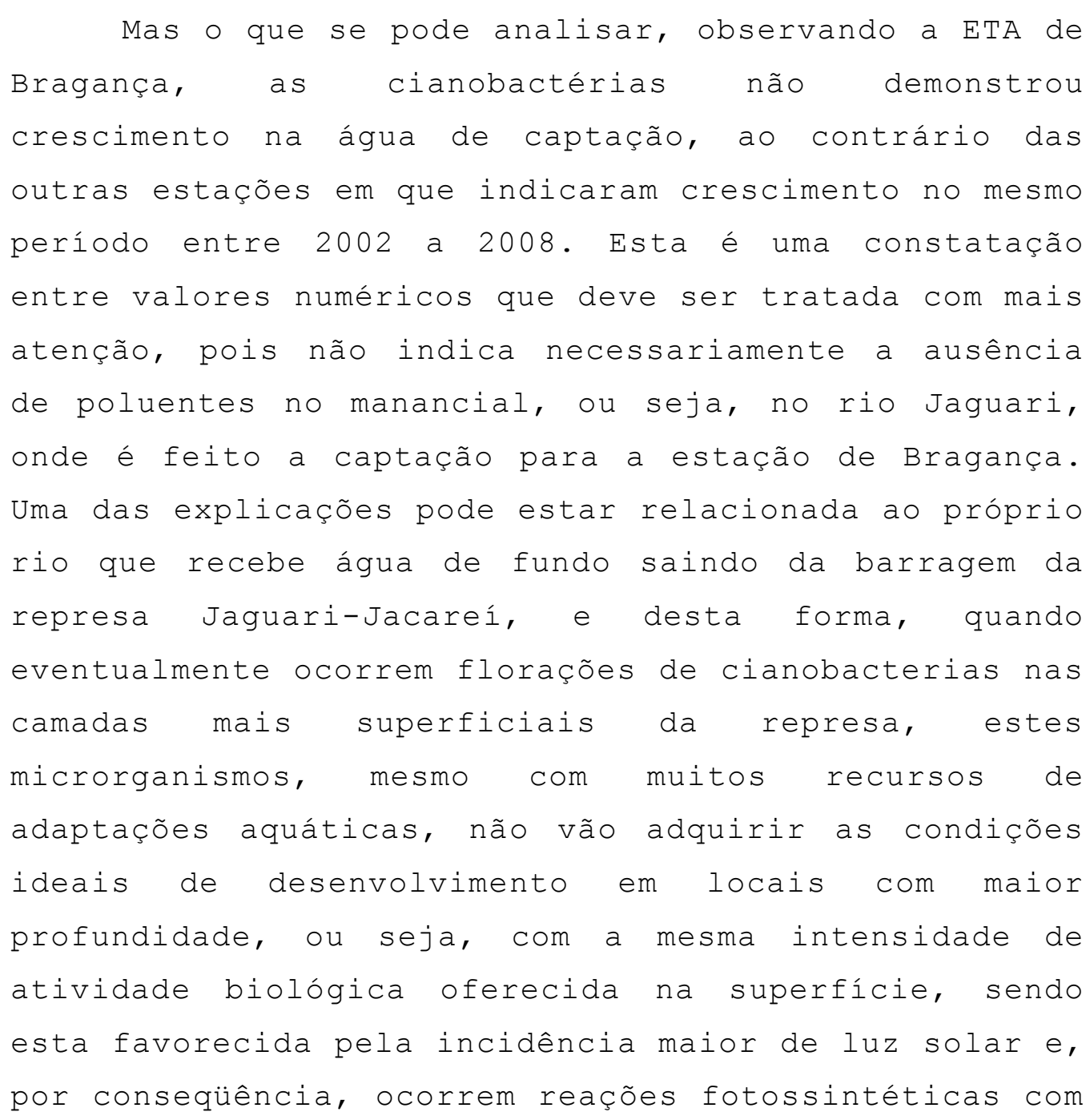


mais facilidade e; portanto, com menor penetração dos raios de luz solar, as águas de fundo que saem da represa estariam com uma densidade muito reduzida de cianobactérias, e sendo assim, as florações que eventualmente possam ocorrer nas camadas mais superficiais da represa, podem não refletir a realidade no rio que abastece a captação desta ETA envolvendo estes dois corpos d'àgua (represa e rio). Pois se sabe que o rio não oferece as mesmas condições em termos limnológicos de desenvolvimento para cianobactérias do que em represa.

7.1.2 Algas Verdes

As algas verdes sofreram um decaimento nas
águas de captação das 4 ETAs no período de 2002 a
2008 (figuras $5,7,9$ e 11 ).

7.1.3 Cianobactérias X Algas Verdes

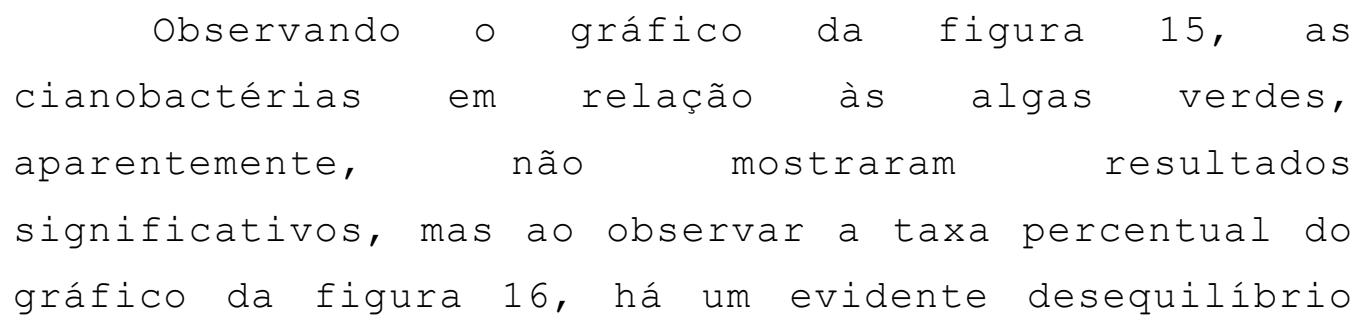




\begin{abstract}
entre os dois grupos de organismos, pois em todas as águas de captação das quatro estações, constatou-se que enquanto as algas verdes sofreram uma diminuição ao longo de 2002 a 2008, as cianobactérias, ao contrário, aumentaram no mesmo período.
\end{abstract}

Comprovou-se através do coeficiente de
correlação de Pearson que há uma forte correlação
entre as variáveis chlorophytas e Cianobactérias,
cujo resultado de $\rho=0,97$ (Coeficiente de correlação
de Pearson) obtido através da tabela 3 foi acima do
coeficiente $0,70$.




\title{
7.2 VARIÁVEIS AMBIENTAIS
}

\subsubsection{Temperatura}

\begin{abstract}
A temperatura destas águas de captação oscilou com maior freqüência na faixa de 20 a $30{ }^{\circ} \mathrm{C}$ (figuras 17, 18, 19 e 20), o que confirma informações, segundo BRANCO (1986, p. 131) que descreve lagos de clima tropical nesta faixa de temperatura, mas houve uma discreta elevação dentro desta faixa.
\end{abstract}

Também, na linha de tendência do gráfico, houve uma faixa de temperatura oscilando entre $20^{\circ} \mathrm{C}$ e $24^{\circ} \mathrm{C}$, então, foram observadas as seguintes oscilações em cada ponto de coleta estudado:

Ponto de coleta (33B1) - rio Jaguari - ETA-Bragança Paulista:

- a temperatura oscilou entre 20 e $22{ }^{\circ} \mathrm{C}$, com linha de tendência iniciando em 2002 acima de $20{ }^{\circ} \mathrm{C}$ e se aproximando de $22{ }^{\circ} \mathrm{C}$ em 2008.

Ponto de coleta (42B1) - rio Cachoeira - ETAPiracaia:

- a temperatura oscilou entre 20 e $22{ }^{\circ} \mathrm{C}$, mantendo-se inalterada a linha de tendência de 2002 a 2008 . 
Ponto de coleta (41B1) - represa Atibainha - ETANazaré Paulista:

- a temperatura oscilou entre 22 e $24{ }^{\circ} \mathrm{C}$, com linha de tendência iniciando em 2002 acima dos $22{ }^{\circ} \mathrm{C}$ e se aproximando de $24{ }^{\circ} \mathrm{C}$ em 2008.

Ponto de coleta (19B1) - represa Paiva Castro-rio Juqueri - ETA-Mairiporã:

- a temperatura manteve-se em torno $22{ }^{\circ} \mathrm{C}$ de 2002 a 2008 .

Apesar de se manterem dentro de uma faixa normal, para regiões tropicais como é o caso do Brasil, houve um pequeno aquecimento em algumas águas de captação, segundo demonstração gráfica indicado pela linha de tendência linear (figuras: 17, 18, 19 e 20). Não se sabe exatamente o que pode estar ocasionando esta elevação, necessitaria de maiores estudos.

7.2.2 Fósforo Total

Águas captadas pela ETA de Bragança Paulista (ponto de coleta: 33B1):

- com aumento de 75 \% na concentração de cianobactérias durante o período compreendido entre 2002 e 2008, observou-se que a água captada pela estação de tratamento de Bragança Paulista começa com 
uma concentração média de Fósforo total em 2004 numa categoria supereutrófica, classificação de estado trófico segundo CETESB (2006), caindo e se mantendo num nível de estado trófico mais baixo, mesotrófico, nos anos de 2005, 2006 e 2007, mas em 2008 houve uma elevação da concentração, chegando ao nível eutrófico, podendo chegar assim numa condição chamada de corpo d'água eutrofizado. Esta água estudada pertence ao rio Jaguari que está influenciada com as águas da represa Jaguari-Jacareí, cuja represa faz parte do Sistema Cantareira, isto pode indicar que este manancial tem uma forte tendência à eutrofização.

Águas captadas pela ETA de Piracaia (ponto de coleta: 42B1):

- com um aumento de 105 \% na concentração de cianobactérias durante o período de 2002 a 2008 , observou-se que a água captada pela estação de tratamento de Piracaia começa com uma concentração média de Fósforo total em 2004 numa categoria oligotrófica, caindo e se mantendo em estado ultraoligotrófico em 2005 e 2006, ou seja, com pouco nutriente de fósforo para um melhor desempenho das cianobactérias, mas em 2007 e 2008 elevou-se a concentração e ultrapassou até mesmo o estado oligotrófico e se manteve em alta no estado mesotrófico, uma condição moderada de eutrofização.

Águas captadas pela ETA de Nazaré Paulista (ponto de coleta: 41B1): 
- com 22 o de aumento na concentração de cianobactérias durante 2002 e 2008, constatou-se em 2004 uma categoria eutrófica na água captada pela estação de Nazaré Paulista na concentração média de Fósforo total, decaindo e se mantendo em estado mesotrófico em 2005, 2006, 2007 e 2008; isto significa, que apesar de cair a concentração média de Fósforo total de 2004 para 2008 , houve uma persistência em se manter num estado de eutrofização moderada por muito tempo, muito próximo da fronteira do nível eutrófico, o que pode tender, dependendo das condições adversas, a subir para uma condição de eutrofização, se não for tomada medidas mais eficazes no controle de contenção do acúmulo de fósforo neste manancial.

Águas captadas pela ETA de Mairiporã (ponto de coleta: 19B1):

- com 179 o de aumento na concentração de cianobactérias durante o período de 2002 e 2008, a água captada pela estação de tratamento de Mairiporã é a que mais preocupa, pois se observou que a concentração média de Fósforo total, começando já em 2004 com um nível mesotrófico, numa condição próxima do processo de eutrofização, caindo e se mantendo em estado oligotrófico em 2005 e 2006, no entanto, nos anos seguintes, ultrapassou o mesotrófico e chegou ao supereutrófico em 2007, só retornando ao estado mesotrófico em 2008 e mesmo assim muito próximo da linha do nível eutrófico; isto indica que a água captada do manancial da represa Paiva Castro-rio Juqueri já está começando a ganhar a condição de um 
corpo d'água eutrofizado. Existe uma peculiaridade nesta região, pois há uma lagoa de estabilização para tratamento de esgoto, a montante, antes da cidade de Mairiporã, sendo que a captação da ETA fica a jusante, depois da cidade, o que pode ser mais um fator de contribuição de nutrientes para alimentar ainda mais as cianobactérias, dependendo do efluente da lagoa lançado no manancial, e que é pertencente ao Sistema Cantareira.

A possibilidade de um maior desenvolvimento do processo de eutrofização do Sistema Cantareira pode ser enfatizada em duas estações de tratamento de água que pertence aos vários mananciais desse mesmo sistema, uma delas são as águas captadas, após a represa Cachoeira, pela ETA de Piracaia e a outra, são as águas captadas, na represa Paiva Castro-rio Juqueri, pela ETA de Mairiporã. Mostraram-se com um aumento de concentração em média de Fósforo Total mais acentuado em suas águas de captação no período de 2004-2008: Piracaia (42B1), começando em 2004 com $0,031 \mathrm{mg} / 1$ (oligotrófico) e aumentando em 2008 para 0,057 mg/l (mesotrófico); e Mairiporã (19B1), começando em 2004 com 0,045 mg/l (mesotrófico) e aumentando em 2007 para 0,135 mg/l (supereutrófico) e voltando ao estado mesotrófico em 2008 para 0,048 $\mathrm{mg} / \mathrm{l}$, neste caso específico, deve se ter um maior cuidado, pois seria necessário observar se haverá uma tendência de aumentar nos próximos anos (figuras 21 e 22 ) . 


\begin{abstract}
Fazendo um balanço geral das quatro ETAs, quanto a concentração de fósforo total em seus mananciais, constatou-se indícios de progressão persistente no acúmulo deste nutriente. Neste caso, o processo de eutrofização já está sendo estimulado, pois se sabe que o fósforo é um nutriente essencial para os organismos vivos, e que geralmente é o nutriente limitante ao crescimento algal, e que ainda, para efeito de contribuição ao já existente, há o acréscimo do fósforo dos esgotos domésticos, efluentes industriais e fertilizantes para elevar os níveis deste nutriente nas águas superficiais, (Ballance, 1996; Chapman \& Kimstach, 1996; Piveli \& Kato, 2006; citado por MATSUZAKI, 2007, p.79).
\end{abstract}

7.2.3 Nitrogênio

As concentrações médias do nitrogênio, tanto para nitrato como para nitrogênio amoniacal, nas águas captadas pelas quatro estações de tratamento mantiveram-se dentro do estabelecido pelo CONAMA$357 / 05$.

o nitrogênio é um excelente indicador da idade de poluição orgânica, ou seja, se houver concentrações elevadas de nitratos, as descargas de esgotos provavelmente encontram-se distante, se houver concentrações elevadas de nitrogênio amoniacal, indica que o foco de poluição encontra-se 
próximo (Cetesb, 2006; Piveli\& Kato, 2006; citado por MATSUZAKI, 2007, p.80).

Mesmo mantendo-se as concentrações de nitrato e nitrogênio amoniacal abaixo dos limites segundo CONAMA, o nitrato mostrou aumento de concentração nas águas de captação das ETAs de Piracaia, Nazaré Paulista e Mairiporã, indicando que a poluição desse macronutriente nesta forma de nitrogênio está se acumulando ao longo do tempo; o nitrogênio amoniacal indicou aumento de concentração nas águas captadas pelas ETAs de Bragança Paulista e Piracaia, mostrando que a poluição de nitrogênio nesta forma está se agravando com descargas de esgotos, provavelmente próximas do ponto de captação ou do manancial, com maior risco para a ETA de Piracaia, já que neste caso as duas formas de nitrogênio aumentaram.

O nitrato, segundo Chapman \& Kimstach, 1996 (citado por MATSUZAKI, 2007, p.81), com níveis de concentrações acima de $0,2 \mathrm{mg} / \mathrm{l} \mathrm{NO}_{3}{ }^{-}$, em lagos, tendem a estimular o crescimento de algas e indicam potencial de eutrofização. Sendo a forma mais oxidada dos compostos de nitrogênio indica a etapa final da decomposição da matéria orgânica. Podem ser provenientes de fontes significativas de fertilizantes químicos em áreas cultivadas, de descargas domésticas e industriais (Ballanca, 1996; citado por MATSUZAKI, 2007, p.81). Outro problema sanitário que preocupa o setor da saúde pública é que os nitratos são considerados compostos tóxicos responsáveis pela metahemoglobina infantil, podendo 
ser uma doença letal para as crianças (Cetesb, 2005; citado por MATSUZAKI, 2007, p.81-82).

7.2.3.1 Nitrato

Apesar da concentração de nitrogênio estar abaixo do limite de $10 \mathrm{mg} / \mathrm{l}$ N exigido pelo CONAMA para nitrato, há três estações mostrando aumento de concentração de nitrogênio na forma de Nitrato em suas águas de captação no período de 2002-2008: Piracaia, Nazaré Paulista e Mairiporã (figura 23).

Águas captadas pela ETA de Bragança Paulista (ponto de coleta: 33B1):

- a concentração de nitrato na água de captação nessa ETA, durante o período de estudo manteve-se em torno de $0,200 \mathrm{mg} / 1 \mathrm{NO}_{3}{ }^{-}$, o que já é motivo de preocupação, já que deste nível de concentração para cima tendem a estimular o crescimento de algas.

Águas captadas pela ETA de Piracaia (ponto de coleta: 42B1):

- nessa estação, sua água de captação, iniciou-se em $2004 \mathrm{com} 0,300 \mathrm{mg} / \mathrm{I} \mathrm{NO}_{3}{ }^{-}$e caiu para $0,190 \mathrm{mg} / 1 \mathrm{NO}_{3}{ }^{-} \mathrm{e}$ $0,164 \mathrm{mg} / \mathrm{I} \mathrm{NO}_{3}{ }^{-}$em 2005 e 2006 respectivamente, mas aumentou para $0,349 \mathrm{mg} / \mathrm{I} \mathrm{N}$ e $0,375 \mathrm{mg} / \mathrm{I} \mathrm{NO}_{3}{ }^{-}$em 2007 e 2008 respectivamente. Estes últimos níveis de 
concentração são indícios preocupantes que podem estimular a eutrofização.

Águas captadas pela ETA de Nazaré Paulista (ponto de coleta: 41B1):

- esta água, em 2004,2005,2006 e 2007, registrou as seguintes concentrações: $0,130 \mathrm{mg}^{\prime} 1 \mathrm{NO}_{3}{ }^{-}, 0,115 \mathrm{mg} / \mathrm{l}$ $\mathrm{NO}_{3}{ }^{-}, \quad 0,125 \mathrm{mg} / \mathrm{I} \quad \mathrm{NO}_{3}{ }^{-}$e $0,075 \mathrm{mg} / \mathrm{l} \quad \mathrm{NO}_{3}{ }^{-}$ respectivamente, e aumentou significativamente para $0,700 \mathrm{mg} / 1 \mathrm{NO}_{3}{ }^{-}$no último ano (2008). Este último pode ser indício preocupante, precisa ser monitorado com mais atenção nos próximos anos.

Águas captadas pela ETA de Mairiporã (ponto de coleta: 19B1):

- manteve a concentração entre $0,170 \mathrm{mg} / 1 \mathrm{NO}_{3}{ }^{-} \mathrm{e}$ $0,186 \mathrm{mg} / \mathrm{NO}_{3}{ }^{-}$entre 2004 e 2006, mas iniciou um aumento em $2007 \mathrm{com} 0,215 \mathrm{mg}^{\prime} \mathrm{NO}_{3}{ }^{-}$e terminando com $0,322 \mathrm{mg} / \mathrm{I} \mathrm{NO}_{3}{ }^{-}$em 2008. Estes valores, seguindo esta seqüência ascendente, são significativos, pois estão acima de $0,200 \mathrm{mg} / 1 \mathrm{NO}_{3}{ }^{-}$(níveis acima deste tende a estimular o crescimento de cianobactérias). 
7.2.3.2 Nitrogênio Amoniacal

Apesar da concentração de nitrogênio estar abaixo do limite do exigido pelo ConAMA para nitrogênio amoniacal, há duas estações mostrando aumento de concentração de Nitrogênio Amoniacal em suas águas de captação no período de 2002-2008: Bragança Paulista e Piracaia (figura 24, 25, 26 e 27).

Águas captadas pela ETA de Bragança Paulista (ponto de coleta: 33B1):

- ocorreu uma discreta tendência na elevação da concentração de nitrogênio amoniacal: 0,065 mg/l $\mathrm{N}-$ $\mathrm{NH}_{3}$ (2004)，0,105 mg/l N-NH3 (2005)，0,100 mg/l N-NH3 $(2006), \quad 0,150 \mathrm{mg} / \mathrm{I} \mathrm{N}-\mathrm{NH}_{3}(2007)$ e $0,085 \mathrm{mg} / \mathrm{I} \mathrm{N}-\mathrm{NH}_{3}$ $(2008)$.

Águas captadas pela ETA de Piracaia (ponto de coleta: 42B1):

- em 2006 registrou-se 3,025 mg/l $\mathrm{N}-\mathrm{NH}_{3}$ em média, valor significativo, próximo do valor máximo permitido no CONAMA-357/05 (3,7 $\left.\mathrm{mg} / \mathrm{l} \quad \mathrm{N}-\mathrm{NH}_{3}\right)$. As concentrações dos demais anos foram: 2004 (0,010 mg/l $\left.\mathrm{N}-\mathrm{NH}_{3}\right), 2005\left(0,190 \mathrm{mg} / \mathrm{I} \mathrm{N}-\mathrm{NH}_{3}\right), 2007(0,175 \mathrm{mg} / \mathrm{I} \mathrm{N}-$ $\left.\mathrm{NH}_{3}\right)$ e $2008\left(0,050 \mathrm{mg} / \mathrm{I} \mathrm{N}-\mathrm{NH}_{3}\right)$.

Águas captadas pela ETA de Nazaré Paulista (ponto de coleta: 41B1): 
- Não houve grandes alterações na concentração de nitrogênio amoniacal em sua água de captação. Registrou em $2004\left(0,160 \mathrm{mg} / \mathrm{l} \mathrm{N}-\mathrm{NH}_{3}\right), 2005(0,425$ $\left.\mathrm{mg} / \mathrm{I} \mathrm{N}-\mathrm{NH}_{3}\right), \quad 2006\left(0,200 \mathrm{mg} / \mathrm{l} \mathrm{N}-\mathrm{NH}_{3}\right), 2007 \quad(0,080$ $\left.\mathrm{mg} / \mathrm{I} \mathrm{N}-\mathrm{NH}_{3}\right)$ e $2008\left(0,110 \mathrm{mg} / \mathrm{I} \mathrm{N}-\mathrm{NH}_{3}\right)$.

Águas captadas pela ETA de Mairiporã (ponto de coleta: 19B1):

- também não houve variações significativas para nitrogênio amoniacal. $2004\left(0,045 \mathrm{mg} / \mathrm{l} \mathrm{N}-\mathrm{NH}_{3}\right), 2005$ $\left(0,270 \mathrm{mg} / \mathrm{I} \mathrm{N}-\mathrm{NH}_{3}\right), 2006\left(0,010 \mathrm{mg} / \mathrm{I} \mathrm{N}-\mathrm{NH}_{3}\right), 2007$ $\left(0,090 \mathrm{mg} / \mathrm{I} \mathrm{N}-\mathrm{NH}_{3}\right)$ e $2008\left(0,060 \mathrm{mg} / \mathrm{I} \mathrm{N}-\mathrm{NH}_{3}\right)$.

7.2.4 Oxigênio Dissolvido

Duas estações, Bragança Paulista e Nazaré Paulista, chamaram atenção em relação ao oxigênio dissolvido em suas águas de captação no período de 2004 a 2008 .

Bragança Paulista: em 2004 estava com níveis aproximadamente de 2,1 mg/l de OD e atingindo em 2008 concentrações aproximadas de $3,8 \mathrm{mg} / \mathrm{l}$ de OD, mesmo estando em elevação, esta última média de concentração de Oxigênio Dissolvido obtida em 2008 ainda é muito baixa em relação às outras águas de captação (figura 28) e em relação valor mínimo exigido pelo CONAMA (Resolução 357/05) que é de 5 
$\mathrm{mg} / \mathrm{l}(\mathrm{OD})$. Na estação de tratamento de água de Bragança Paulista pode haver uma situação peculiar, pois a água captada no rio Jaguari se realiza logo após a passagem da água de fundo que sai da barragem da represa Jaguari-Jacareí, devido a pouca distância do percurso do rio saindo da represa até a ETA, e assim o tempo gasto pode não ser suficiente para a sua reoxigenação. Para maior destaque, verifica-se também, na tabela 5, uma relação entre a cor muito alta (que deveria ser $\leq 75 \mathrm{mg}$ Pt-Co/L) e oxigênio dissolvido muito baixo (que deveria ser $\geq 5 \mathrm{mg} / \mathrm{l}$ ).

Este fato de cor elevada pode estar relacionado a poucas algas e outros vegetais fotossintetizantes nesta água, pois segundo BRANCO (1986, p.338), há uma dificuldade à penetração de luz, que é essencial à fotossíntese. Desta forma, conclui-se, em havendo pouca fotossíntese, também haverá pouca oxigenação da água.

Já em Nazaré Paulista há uma queda de concentração média de Oxigênio Dissolvido entre os anos de 2004 e 2008, iniciando em 2004 com 8,0 mg/l e terminando em $2008 \mathrm{com} \mathrm{5,8} \mathrm{mg/l} \mathrm{(figura} \mathrm{28).}$

Para os responsáveis que trabalham na área de saúde pública, a importância de águas bem oxigenadas deve ser um fator de grande significado, pois a oxigenação da água, seja por meios de reaeração a partir da atmosfera em águas agitadas, ou por fotosíntese, desempenha papel importante na destruição de seres patogênicos, que geralmente são 
organismos de vida anaeróbia com potencial para o desenvolvimento de doenças intestinais (BRANCO, 1986, p.279).

7.2.5 Cor, Turbidez e pH

Observando a cor, o pH e a Turbidez das 4
estaçõe, os parâmetros que mais chamaram atenço
foram a cor e a turbidez com valores baixos na água
de captação da ETA de Nazaré paulista, isto pode
explicar em parte um dos motivos de um maior
desenvolvimento de cianobactérias, inclusive algas
verdes, em relação às outras estações. o fitoplâncton
neste ambiente aquático, com menos interferentes de
impedimento a passagem de luminosidade, ou seja, com
menos cor e menos turbidez, podem realizar
fotossintese com mais facilidade (observação dos
dados na tabela 4 ). Mas, de um modo geral, os dados
destes parâmetros encontrados nas águas de captação
destas estações do sistema cantareira podem ser
considerados normais.


a) $\operatorname{Cor}$

Ponto de coleta (33B1):

- nesta ETA, constatou-se em média anual, de 2002 a 2008, uma cor alta na água de captação do rio Jaguari que abastece a cidade de Bragança Paulista, em relação ao máximo estabelecido pelo CONAMA para água doce - classe II (Resolução-357/05) que é de 75 mg Pt-Co/L. Como já foi comentado para Oxigênio Dissolvido, esta constatação pode ter relação com a baixa oxigenação desta água.

Pontos de coleta (42B1, 41B1 e 19B1):

- nestas outras ETAs, Piracaia, Nazaré Paulista e Mairiporã, não se verificaram uma concentração de cor fora do parâmetro estabelecido pela norma vigente.

b) Turbidez

Durante o período de estudo (2002 a 2008), a turbidez de todas as águas de captação das quatro estações mantiveram-se dentro do estabelecido para água doce - classe II (CONAMA-357/05), ou seja, abaixo de 100 UT.

Pode-se constatar que as água mais "limpas", em relação à turbidez, foram as de Piracaia e Nazaré Paulista, isto é, a água da ETA de Piracaia captada do rio Cachoeira (ligado a represa Cachoeira) variou em média de 7 a 12 UT, e água da ETA de Nazaré 
Paulista captada da represa Atibainha variou em média de 2 a 4 UT, sendo a menor turbidez entre as quatro ETAs.

Em relação a ETA de Mairiporã, a água captada da represa Paiva Castro-rio Juqueri variou em média de 8 a 17 UT, e em Bragança Paulista, a água de captação do rio Jaguari (ligado a represa JaguariJacareí) com a maior turbidez entre as quatro ETAs, a variação média ocorreu de 15 a 34 UT, isto pode ser explicado, juntamente com a cor que é alta neste ponto (33B1), em parte, a pouca quantidade de algas, inclusive com baixa densidade de cianobactéria.

\section{c) $\mathrm{pH}$}

Nas quatro estações, o potencial hidrogeniônico das águas de captação, manteve-se entre 2002 e 2008 geralmente dentro da variação de pH entre 6 e 9 para água doce - classe II (CONAMA-357/05). Alguns pontos como em Nazaré Paulista (41B1) houve registro de pH = 4,6 (em 2005), ficando abaixo do pH mínimo, e em Mairiporã (19B1), em $2003(\mathrm{pH}=5,9)$, em $2004(\mathrm{pH}=$ $5,0)$ e em $2005(\mathrm{pH}=4,4)$. Estes valores podem ser pontuais, já que a amostragem analisada indicou resultados em sua maioria dentro da faixa de $\mathrm{pH}=6 \mathrm{e}$ $\mathrm{pH}=9$.

O pH, geralmente, tem efeito indireto sobre os organismos exercendo influência à toxidez de certos compostos, tais como amônia, metais pesados e gás 
sulfídrico. Uma variação de pH muito grande num ambiente aquático causada por lançamento de ácidos fortes pode afetar a flora e a fauna de uma massa d'água, por exemplo, mortalidade de peixes, sendo este fato assunto de objeto de estudos (BRANCO, 1986, p. 340$)$.

Neste caso, do Sistema Cantareira, verificou-se neste estudo que a densidade em geral de algas ou cianobactérias é relativamente baixa. Mas florações ocasionais nestes mananciais do Sistema Cantareira podem elevar o pH da água em alguns momentos. Segundo BRANCO (1986, p.263), as algas através do processo de fotossíntese retiram gás carbônico do meio, causando a precipitação de carbonatos, podendo atingir valores altos (até 10,0$)$, por outro lado, durante a noite, na ausência de luz, cessando a atividade fotossintetizante, passa a predominar a reação contrária, da respiração, com conseqüente enriquecimento do meio em gás carbônico, provocando a dissolução dos carbonatos e como resultado ocorre o abaixamento do pH. Essa oscilação acarreta várias dificuldades de operação nas estações de tratamento, levando ao desperdício de coagulantes, pois densidade elevada de algas, na água a ser tratada, induz à formação de flocos fracos, de grande tamanho, principalmente quando em sua formação estão presentes algas e cianobactérias que tendem a flutuar como Anabaena e Coelosphaerium, para isso, utiliza-se agitação mecânica para formar flocos menores, assim há uma melhor sedimentação, resultando em uma menor cor e turbidez na água decantada. Para abaixar o pH 
que eventualmente se eleva em decorrência da fotossintese de águas ricas destes microrganismos e se manter a níveis compatíveis com a coagulação, muitas estações de tratamento, nesta situação, utilizam determinados recursos, para evitar o excesso de aplicação de sulfato de alumínio, como a adição de ácido sulfúrico ou, em muitos casos, evita-se o uso de aeradores, que possam causar a perda do gás carbônico resultante da reação com o sulfato de alumínio.

7.3 RELAÇÕES ENTRE AS VARIÁVEIS BIÓtICAS E ABIÓTICAS

As atividades de origem antrópicas neste trabalho foram relacionadas às variáveis ambientais ou abióticas que aqui mencionadas são consideradas como sendo Temperatura, Fósforo, Nitrogênio e Oxigênio Dissolvido e que podem atuar em conjunto influenciando as variáveis bióticas ou biológicas, a vida aquática, como por exemplo, influência sobre o fitoplâncton, neste caso, as cianobactérias e as algas verdes. Sendo estas últimas, a que normalmente respondem negativamente, ou seja, sofrem mais decaimento em sua massa algal, se o meio ambiente estiver poluído, ou uma resposta positiva se este meio estiver em boas condições naturais, ou seja, em equilíbrio. Ao contrário das algas verdes, as cianobactérias podem se aproveitar deste ambiente, 
apesar de poluído, mas com matéria orgânica rica em nutriente, o suficiente para que elas lancem seus recursos naturais de adaptações em situações adversas para se alimentarem. De 2002 a 2008, devido, possivelmente, a um aumento de poluentes derivados de matéria orgânica, o fósforo tem aumentado nas águas de captação das estações de Piracaia (figura 21) e Mairiporã (figura 22), e o nitrogênio na forma de nitrato (figura 23) também aumentou em Nazaré, juntamente com Piracaia e Mairiporã; já o oxigênio dissolvido (figura 28) está com um decaimento em Nazaré Paulista (represa Atibainha), mas, ainda assim, acima de $5 \mathrm{mg} / \mathrm{L}$ (OD) para água doce - classe II, e com baixos níveis em Bragança Paulista (rio Jaguari), bem abaixo dos $5 \mathrm{mg} / \mathrm{L}$ (OD) (CONAMA-357/05), este baixo teor de oxigênio dissolvido na água captada pela ETA de Bragança pode estar, além de outros fatores, associado a pouca presença de algas, pois há um teor alto de cor dessa água que pode estar obstruindo a passagem de luz, e conseqüentemente impedindo uma maior atividade da massa algal que poderia contribuir para uma maior produção de oxigênio na água. Somando-se ainda a estas variáveis, foi detectado um aumento discreto da temperatura em algumas dessas águas de captação, rio Jaguari (figura 17) e a represa Atibainha (figura 19), talvez por motivos naturais ou por outros fatores como de origem antrópica que poderia estar associado ao aquecimento global (objeto de estudos atualmente), e como se sabe, segundo BRANCO (1986, p.339), certos tipos de algas, como diatomáceas e cianonobactérias ("algas azuis"), podem viver bem em temperaturas, às vezes, 
mesmo superiores a $40{ }^{\circ} \mathrm{C}$. Condições adversas de temperatura provocam também uma adaptação semelhante à seleção produzida pela introdução de despejos químicos e domésticos, em que o ambiente passa a ser ocupado por apenas uma ou poucas espécies de organismos que se multiplicam com grande intensidade. Assim sendo, as cianobactérias, aqui estudadas, é um desses poucos organismos que crescem com facilidade nessas condições ambientais adversas, se tornando bons indicadores de poluição, então, de um modo geral, pode se observar, através das águas de captação das estações de tratamento que seus respectivos mananciais estão sofrendo degradação ambiental ao longo do tempo.

Outra observação, não se pode simplesmente concluir que um ambiente aquático está livre de poluição por estar com densidade muito baixa de cianobactérias, pois só esta constatação, sem levar em conta a associação com outras variáveis, seja biológica ou abiótica, pode levar a um diagnóstico equivocado. Águas muito ricas em nutrientes, como fósforo e nitrogênio, podem ser consideradas eutrofizadas, mas não significa que sempre vão ocorrer florações de cianobactérias nesta condição, poderão ocorrer na medida em que outras variáveis sejam bióticas e ou abióticas forem favoráveis. Um exemplo deste é o caso da ETA de Bragança Paulista, que tem em sua água de captação do rio Jaguari um potencial de aumentar o crescimento da massa algal, inclusive, florações de cianobactérias, pois há nutrientes suficientes para atingir um estado de 
eutrofização, mas isto não ocorre, pois as condições físicas e químicas não favorecem. Como é um rio, diferente das condições de uma represa, e também principalmente pelo fato de possuir uma concentração de cor muito alta, é uma água bruta escura que desfavorece a penetração de luz mais intensa que promoveria um melhor processo de fotosíntese de algas ou por cianobactérias, e por conseqüência poderia aumentar o seu teor de oxigênio dissolvido na água, já que também é outro problema por possuir uma concentração de OD muito baixa. Isto não significa que o correto seria criar um ambiente favorável só para o crescimento de algas no corpo d'água, mas promover um equilíbrio entre as variáveis bióticas e abióticas seria o ideal.

Observando as tendências dos gráficos
destacaram-se as águas de captação das ETAs de
Piracaia e Mairiporã com 3 variáveis (Cianobactérias,
Fósforo total e Nitrato) tendendo a aumentar. Para a
ETA de Nazaré: destacaram-se as cianobactérias e
nitrato aumentando. Para a ETA de Bragança: destacou-
se o OD muito baixo.




\title{
8 CONSIDERAÇÕES FINAIS
}

\begin{abstract}
Com relação às estações de tratamento de água pertencentes ao Sistema Cantareira, há evidências através das cianobactérias indicando que as condições encontradas nas águas de captação estão evoluindo aos poucos negativamente, mas que tais condições poderão piorar nos próximos anos dependendo da intensificação e do tipo de atividade antrópica na região onde se localiza o sistema Cantareira.
\end{abstract}

Considerando o período de 2002 a 2008 ,
crescimento de cianobactérias nas águas de captaço
das estações de tratamento de água, que direta ou
indiretamente pertencem aos mananciais abastecedores
do sistema cantareira, há indicações de alerta que
chamaram a atenção em relação às represas Juqueri-
Jacareí, Cachoeira, Atibainha, e Paiva Castro. Sendo
as cianobactérias a variável principal deste
trabalho, pode se constatar que houve aumentos
consideráveis deste microrganismo, ou seja, 75\% na
represa Juqueri-Jacareí, $105 \%$ na represa Cachoeira,
$22 \%$ na represa Atibainha, e $179 \%$ na represa Paiva
castro-rio Juqueri.

Comparando as cianobactérias com as algas verdes pode se notar também que, ao longo do período de 2002 a 2008, há uma clara evidência indicando que estes dois grupos de microrganismos desenvolveram-se 
em sentido contrário, enquanto as cianobactérias cresceram, as algas verdes reduziram o seu crescimento (figura 18), é mais um indicativo de mudança ambiental dos corpos d’águas, ou seja, gradualmente, ao longo dos anos os poluentes são introduzidos nos mananciais.

Para melhoria do tratamento, outras variáveis como pH, cor e turbidez são importantes para se fazer um bom acompanhamento passo a passo na operação da estação, pois estas variáveis podem contribuir para o desenvolvimento de cianobactérias ou serem influenciadas por estes microrganismos, exemplo, uma floração de cianobactérias pode aumentar a turbidez da água.

Como sugestão, o monitoramento da qualidade das águas destes mananciais deve ser constante no sentido de se obter melhores informações das condições ambientais destes corpos d'água, envolvendo fatores bióticos e abióticos deste ambiente. Sendo estas informações mais precisas, medidas de ações preventivas poderão ser mais eficientes no combate a causa. Exemplo, a contribuição de cargas poluidoras, como o excesso de fósforo e nitrogênio que torna estes corpos d'água eutrofizados, pois são nutrientes de vital importância para o surgimento de florações de cianobactérias com maior freqüência atualmente nos mananciais utilizados para o abastecimento de água potável a população, e se nenhuma medida for tomada no sentido de se evitar a poluição das águas, o combate as conseqüências sempre serão piores do que 
na origem do problema. Exemplo, para minimizar os efeitos de uma água com gosto e odor que a população reclama, é necessário gastar muito com carvão ativado, sendo que medidas preventivas seria a melhor solução. Medidas estas que podem ser: evitar a descarga de esgoto doméstico, rico em nutrientes, nas represas para não propiciar a proliferação das cianobactérias em excesso.

O interesse por este trabalho foi devido à preocupação em decorrência da escassez de águas de boa qualidade e para que haja mais ações preventivas e, portanto, não devendo ocorrer negligência a mananciais de grande importância como do Sistema Cantareira, pois são águas superficiais consideradas relativamente de boa qualidade e conseqüentemente ideais para que se realize um bom tratamento. Estes mananciais, pertencentes deste sistema, são recursos naturais inestimáveis que demandaram obras gigantescas com muitos custos, e para que através destas obras se pudessem transportar águas de longas distâncias com vital importância para o consumo de uma grande população, ou seja, aproximadamente a metade da capital de São Paulo e de grande parte da região metropolitana. 


\section{REFERÊNCIAS BIBLIOGRÁFICAS BÁSICAS}

AMERICAN PUBLIC HEALTH ASSOCIATION. Standard methods for the examination of water and wastewater. 18th ed. Washington, D.C.: APHA, 1998. p.1-1268.

BEYRUTH, Z., SANT'ANNA, C. L., AZEVEDO, M. T. P., CARVALHO, M. C., PEREIRA. H. A. S. L Toxic algae in freshwaters of São Paulo State. In: CORDEIRO, M. M., AZEVEDO, M. T. P, SANT'ANNA, C. L., TOMITA, N.Y., PLASTINO, E. N. Algae and environment: a general approach. São Paulo: Sociedade Brasileira de Ficologia; 1992. p. 53-60.

BEYRUTH, Z Comunidades fitoplanctônica da Represa de Guarapiranga: 1991-92. Aspectos ecolocógicos, sanitários e subsídios para reabilitação da qualidade ambiental. 1996. Tese (Doutorado em Saúde Pública) Faculdade de Saúde Pública, Universidade de São Paulo, São Paulo.

BICUDO, C. E. M.; BICUDO R. M. T. Algas de águas continentais brasileiras. São Paulo: Fundação Brasileira para o Desenvolvimento do Ensino de Ciências; 1970 .

BICUDO, C. E. M.; MENEZES, M. Gêneros de algas de águas continentais do Brasil (chave para identificação e descrição). 2. ed. São Carlos: RiMa; 2006 .

BRANCO, S. M. Hidrobiologia Aplicada à Engenharia Sanitária. 3. ed. São Paulo: Cetesb; 1986.

CONAMA, RESOLUÇÃO $\mathrm{N}^{\circ}$ 357. Brasil. Ministério do Meio Ambiente. Dispõe sobre a classificação dos corpos de água e diretrizes ambientais para o seu enquadramento, bem como estabelece as condições e padrões de lançamento de efluentes, e dá outras providências. Brasilia, DF, 2005.

FUNASA. Brasil, Ministério da Saúde. Cianobactérias tóxicas na água para consumo humano na saúde pública e processos de remoção em água para consumo humano. Brasilia, DF - 2003. www.cvs.saude.sp.gov.br/pdf/cianobacterias.pdf 
CETESB. Secretaria de Estado do Meio Ambiente. Relatório de Qualidade das Águas Interiores do Estado de São Paulo: índices de qualidade das águas. São Paulo, SP, 2007 .

CETESB. Secretaria de Estado do Meio Ambiente. Relatório de Qualidade das Águas Interiores do Estado de São Paulo: índices de qualidade das águas. São Paulo, SP, 2008 .

ESTEVES, F. A. Fundamentos de limnologia. 2. ed. Rio de Janeiro: Interciência, 1998.

Gemelgo, M. C. P. Estrutura e dinâmica da comunidade fitoplanctônica dos Reservatórios Billings e Guarapiranga, SP, Brasil. 2008. 161 f. Tese (Doutorado em Ciências) - Instituto de Ciências Biomédicas, Universidade de São Paulo, São Paulo.

MATSUZAKI, M., MUCCI, J. L. N. \& ROCHA, A. A. Comunidade fitoplanctônica de um pesqueiro na cidade de São Paulo. Rev. Saúde Pública 38(5) 679-86. São Paulo, 2004 .

MATSUZAKI, M. Transposição das águas do braço Taquacetuba da represa Billings para a represa Gaurapiranga: aspectos relacionados à qualidade de água para abastecimento. 2007. 181 p. Tese (Doutorado em Saúde Pública) - Faculdade de Saúde Pública, Universidade de São Paulo, São Paulo.

MELCHER, S. S. Estudos morfológicos e moleculares de cianobactérias potencialmente tóxicas dos gêners Cylindrospermopsis, Apahnizomenon e Raphidiopsis (Nostocales). São Paulo: Instituto de Botânica da Secretaria de Estado do Meio Ambiente; 2008.

PDAA. Plano Diretor de Abastecimento de Água da Região Metropolitana de São Paulo. São Paulo: Encibra; 2006 .

PORTARIA, $\mathrm{N}^{\circ}$ 518. Brasil. Ministério da Saúde. Estabelece os procedimentos e responsabilidades relativos ao controle e vigilância da qualidade da água para consumo humano e seu padrão de potabilidade, e dá outras providências. Brasília, DF, 2004 . 
SABESP Banco de dados de programa em sistema eletrônico: Unicorp (Unimaster/Unilab/Netcontrol) Laboratório do Controle Sanitário Norte da Sabesp (mnec). São Paulo, SP, 2009.

SABESP Sistema Cantareira <URL> http://www.mananciais.org.br/site/mananciais_rmsp/can tareira (acessado em 23 de março de 2010)

SANT'ANNA, C. L.; MELCHIER, S. S.; CARVALHO, M. C.; GEMELGO, M. P.; AZEVEDO, M. T. P. Cianobactérias planctônicas em reservatórios do Alto Tietê. São Paulo: Revista Brasil. Bot., V.30, n.1,p.1-17, jan.mar. 2007 .

SOARES, J. L. Dicionário etimológico e circunstanciado de biologia. Editora Scipione. São Paulo, SP - 1993.

THOMAS, P. T. (2006). Repartição das vazões transpostas da bacia hidrográfica do rio Piracicaba para a bacia hidrográfica do Alto Tietê pelo Sistema Cantareira para fins de cobrança pelo uso de recursos hídricos. Nota Técnica n019/2006/SOC-ANA. BrasíliaDF . $11 \mathrm{p}$. $<$ URL $>$ http: / /www.ana.gov.br/CobrancaUso/ pdfs/ArtigoABRHCan tareira01-06-07.pdf (último acesso: 24/08/2009).

SZAJUBOK, A. L. F. R. O desenvolvimento da comunidade fitoplanctônica na represa Guarapiranga no período de 1994 a 1997. 2000. 182 p. Dissertação (Mestrado em Saúde Pública) - Faculdade de Saúde Pública, Universidade de São Paulo, São Paulo.

TUNDISI, J. G.; MATSUMURA, T. Limnologia. São Paulo: Oficina de Textos, 2008 .

WHATELY, M.; CUNHA, P. Cantareira 2006: um olhar sobre o maior manancial de água da Região Metropolitana de São Paulo: "Resultados do Diagnóstico Socioambiental Participativo do Sistema Cantareira". São Paulo: Instituto Socioambiental, 2007 . $<\mathrm{URL}>$ http://www.mananciais.org.br/upload / cantareira2006.p df (último acesso: 24/08/2009). 